Article

\title{
ZVI $\left(\mathrm{Fe}^{0}\right)$ Desalination: Stability of Product Water
}

\author{
David D. J. Antia \\ DCA Consultants Ltd., Haughend, Bridge of Earn Road, Dunning, Perthshire PH2 9BX, UK; \\ dcacl@btconnect.com; Tel.: +41-1764-684-664 \\ Academic Editor: Andelka Belic \\ Received: 25 December 2015; Accepted: 23 February 2016; Published: 3 March 2016
}

\begin{abstract}
A batch-operated ZVI (zero valent iron) desalination reactor will be able to partially desalinate water. This water can be stored in an impoundment, reservoir or tank, prior to use for irrigation. Commercial development of this technology requires assurance that the partially-desalinated product water will not resalinate, while it is in storage. This study has used direct ion analyses to confirm that the product water from a gas-pressured ZVI desalination reactor maintains a stable salinity in storage over a period of 1-2.5 years. Two-point-three-litre samples of the feed water $\left(2-10.68 \mathrm{~g}\left(\mathrm{Na}^{+}+\mathrm{Cl}^{-}\right) \cdot \mathrm{L}^{-1}\right)$ and product water $\left(0.1-5.02 \mathrm{~g}\left(\mathrm{Na}^{+}+\mathrm{Cl}^{-}\right) \cdot \mathrm{L}^{-1}\right)$ from 21 trials were placed in storage at ambient (non-isothermal) temperatures (which fluctuated between -10 and $25^{\circ} \mathrm{C}$ ), for a period of $1-2.5$ years. The ion concentrations $\left(\mathrm{Na}^{+}\right.$and $\left.\mathrm{Cl}^{-}\right)$of the stored feed water and product water were then reanalysed. The ion analyses of the stored water samples demonstrated: (i) that the product water salinity $\left(\mathrm{Na}^{+}\right.$and $\left.\mathrm{Cl}^{-}\right)$remains unchanged in storage; and (ii) the $\mathrm{Na}: \mathrm{Cl}$ molar ratios can be lower in the product water than the feed water. The significance of the results is discussed in terms of the various potential desalination routes. These trial data are supplemented with the results from 122 trials to demonstrate that: (i) reactivity does not decline with successive batches; (ii) the process is catalytic; and (iii) the process involves a number of steps.
\end{abstract}

Keywords: desalination; zero valent iron $\left(\mathrm{ZVI} ; \mathrm{Fe}^{0}\right)$; irrigation; ion concentration; $\mathrm{Na}^{+}$ions; $\mathrm{Cl}^{-}$ions

\section{Introduction}

Desalination associated with zero valent iron $\left(\mathrm{ZVI}, \mathrm{Fe}^{0}\right)$ has been demonstrated in more than 160 batch trials (utilizing $0.2-240 \mathrm{~L} /$ batch [1-5]) and by monitoring the salinity of water flowing through granular $\mathrm{Fe}^{0}$ permeable reactive barriers (PRB) [6-10]. These trials have demonstrated that ZVI desalination has potential applications for groundwater management, road runoff water management, agricultural water management, municipal and domestic water, emergency and disaster water requirements, feed and waste water treatment associated with conventional desalination plants, waste water associated with the extractive industries and environmental damage mitigation [1-10].

The major potential market for ZVI desalination product water is the provision of partially-desalinated water for irrigation [2]. Salinization affects $260-1000$ billion $\mathrm{m}^{3}$ /a of irrigation water $[2,11-16]$.

There is an increasing requirement for desalinated (or partially desalinated) water to sustain agriculture (for wheat, barley, oil palm, cotton, soybean, maize, sugar cane, etc.) as the alternative water sources become salinized [17]. Irrigation with desalinated water (when compared to irrigation with salinated water) may produce a small (\$/ha) increase in crop value [2]. The increase in crop value is unlikely to economically sustain the delivery cost of desalinated, or partially desalinated, water of more than $\$ 0.1-\$ 0.5 / \mathrm{m}^{3}[2]$.

A reverse osmosis (RO) desalination plant producing $600-500,000 \mathrm{~m}^{3} /$ day requires an external energy source, which is in the range of $2.5-9.38 \mathrm{kWh} / \mathrm{m}^{3}$ of product water $[18,19]$. Similar amounts of external energy are required for each of the alternative desalination technologies (e.g., mechanical 
vapour compression (MVC), thermal vapour compression (TVC), multistage flash distillation (MSF), multistage vacuum membrane distillation (MSVM), electrolysis desalination (ED), humidification desalination (HDHD) and multi-effect distillation (MED) [18,19].

The product water delivery cost from a large-scale $\left(100,000 \mathrm{~m}^{3} /\right.$ day) desalination plant varies internationally. The delivery cost is typically in the range of $\$ 2.5-\$ 4 / \mathrm{m}^{3}$, e.g., [2,20-23]. These delivery costs may increase substantially (e.g., by an order of magnitude) for small-scale plants producing less than 250-1000 $\mathrm{m}^{3}$ / day [20-23]. It is highly unlikely that these small-scale plants will be able to produce desalinated water for a delivery price of $\$ 0.1-\$ 0.5 / \mathrm{m}^{3}$.

Green (solar powered) desalination systems based on solar photovoltaic (PV) cells [24] and solar membrane distillation technology [25] are capital intensive and require a large land take. Solar membrane technology producing $0.5-1 \mathrm{~m}^{3} /$ day has been demonstrated to have an operating cost within the range of $\$ 5-\$ 16 / \mathrm{m}^{3}$ [25].

A new redox chemical route for the partial desalination of water using ZVI was discovered in 2010 [3,26]. Subsequent investigations [1,2,4,5] established that this technology could be used to partially desalinate small water bodies (e.g., 1-10,000 $\mathrm{m}^{3}$ ). The anticipated delivery cost from a commercial unit is considered to fall within the range of $\$ 0.001-\$ 0.5 / \mathrm{m}^{3}$ [2]. A number of different reactor combinations, reactor types, reactor configurations and ZVI combinations have been trialed [1-5,26]. The two principal reactor technologies (based on ZVI diffusion redox chemistry and a ZVI particle size of 44,000-77,000 $\mathrm{nm}$ ) are:

1. Static diffusion technology [1,2];

2. Gas-pressured static diffusion technology [2].

Static diffusion ZVI partial desalination reactors operate at atmospheric pressure with a low air saturation in the water [2]. The air saturation of the water is controlled by diffusion across the air-water interface [2]. The gas-pressured static diffusion reactors use a pressured gas body placed above the gas-water contact to pressurize the water [2]. A gas is bubbled through the water to allow high levels of gas saturation to occur [2]. The gas bubbles are used to increase the available diffusion surface area between the gas and the water [2].

\subsection{Static Diffusion ZVI Partial Desalination}

This technology places ZVI-derived products (e.g., pellets, or granules, or powders) [1,2] in a static body of water (e.g., an existing tank (Figure 1), pond or impoundment). The ZVI concentration is within the range of $0.3-90 \mathrm{~g} \cdot \mathrm{ZVI} \cdot \mathrm{L}[1,2]$. The water in the tank is not stirred, or agitated, and is maintained at ambient atmospheric (or ground) temperatures within the range of $-10-55^{\circ} \mathrm{C}$ [2]. The water salinity declines gradually (exponentially) over a prolonged time period to a base salinity level $\left(B_{S}\right)$ over a period of 30-250 days [1,2]. The length of time $\left(t_{B S}\right)$ taken to achieve the base salinity level varies with the ZVI composition and the manufacturing method used to produce the ZVI-derived product $[1,2]$. The attainable base salinity level $\left(B_{s}\right)$ has been demonstrated to be between $5 \%$ and $50 \%$ of the feed water salinity [1,2]. The base salinity level (expressed as a proportion of the feed water salinity) is independent of the feed water salinity [2]. This characteristic of the ZVI desalination process confirms that the desalination follows a pseudo-n-th order process [27]. The ZVI can be reused to partially desalinate at least three batches of water sequentially, where the rate of salinity decline may decrease (and $B_{S}$ increase) with each succeeding batch of water $[1,2]$. Desalination removes both $\mathrm{Na}^{+}$ions and $\mathrm{Cl}^{-}$ions in equal molar proportions [1,2].

The salinity of the product water produced using this approach has been demonstrated to remain stable for more than one year [1,2] and is not addressed further in this study.

This technology requires no external energy and can use existing water tanks, ponds, reservoirs and impoundments [2]. It is therefore suitable for application in areas with no energy infrastructure, small agricultural holdings and agricultural units with limited access to capital financing. 
The residual ZVI can be reused for water treatment [2] or for gas desulphurization [2]. In some regions, the resale price of the residual ZVI may exceed the purchase cost of the ZVI treatment product [2]. In these circumstances, this desalination technology, when used for irrigation, can still increase the profitability of an agricultural holding, even when no noticeable increase in crop yield occurs [2].

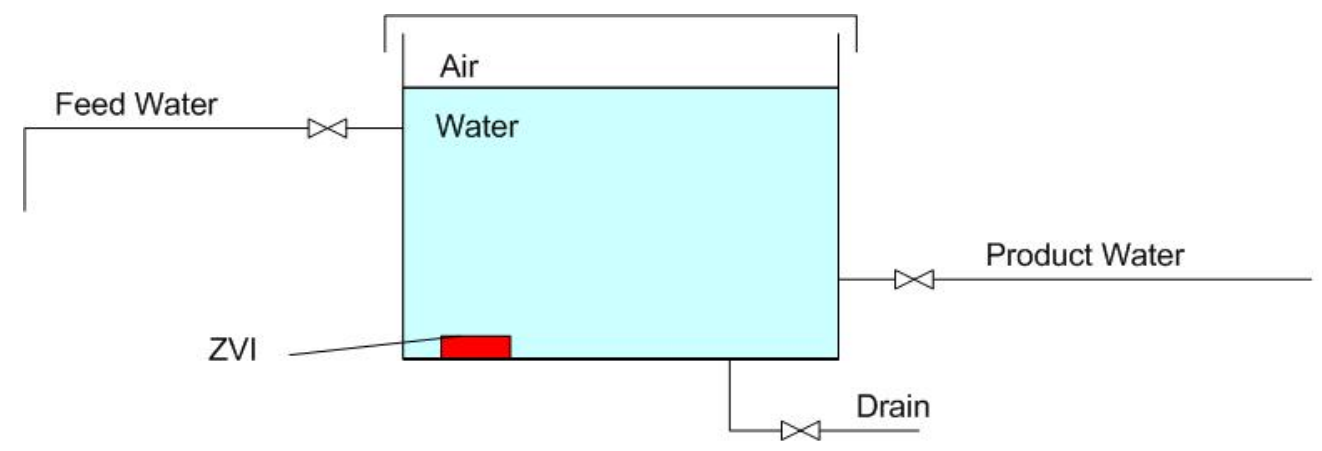

Figure 1. Schematic process flow diagram for a static diffusion ZVI partial desalination reactor.

\subsection{Gas-Pressured Static Diffusion ZVI Partial Desalination}

Many smaller land holdings do not have sufficient water storage (or land that could be used for water storage) to allow the static diffusion ZVI partial desalination to be a practical option.

Compact gas-pressured (less than $0.1 \mathrm{MPa}$ ) static diffusion reactors (utilizing air or $\mathrm{CO}_{2}$ as the pressurizing agent) operated at ambient temperatures were found to achieve a base salinity level $\left(B_{S}\right)$ within a time frame $\left(t_{B S}\right)$ of 2-24 $\mathrm{h}$ [2]. These reactors (Figure 2) established that the rate of desalination is a function of the gas saturation of the water and the gas pressure [2]. The desalination rate increases with increased gas saturation and gas/water pressure to an equilibrium salinity level $\left(B_{S}\right)$ [2].

The gas-pressured static diffusion reactor trials established [2]:

1. A single ZVI (or ZVI product) charge can be reused to partially desalinate multiple batches of water [2]:

a A single ZVI charge can be reused at least 18 times [2];

$\mathrm{b}$ The rate of salinity decline is unaffected by:

i reuse of the ZVI [2];

ii the salinity of the feed water [2].

2. Partial desalination of brackish water (less than $10 \mathrm{~g} \mathrm{NaCl} \cdot \mathrm{L}^{-1}$ ) to a base salinity level $\left(B_{s}\right)$ can be undertaken at ambient temperatures (e.g., $0-55^{\circ} \mathrm{C}$ ) [2]:
a $\left(t_{B S}\right)$ is $2-24 \mathrm{~h} \mathrm{[2];}$
b $\left(B_{S}\right)$ is between $5 \%$ and $90 \%$ of the $\mathrm{NaCl}$ held in the feed water [2];
c $\left(B_{s}\right)$ is independent of ZVI reuse [2].

3. The ZVI:water ratio in the reactor can be in the range of $0.5-30 \mathrm{~kg} Z \mathrm{ZVI}$ charge: $1 \mathrm{t}$ water [2]. The $\mathrm{ZVI}$ is held in a replaceable cartridge, which is attached to the reactor via a manifold [2].

The trial results [2] have established that a compact gas-pressured reactor containing $10 \mathrm{~m}^{3}$ of water has the potential to produce between 3600 and $29,000 \mathrm{~m}^{3}$ of partially-desalinated water (for irrigation applications) over the course of a year. 
1.2.1. Indicative Dimensions and Costs of a Gas-Pressured Reactor with a Batch Capacity of $10 \mathrm{~m}^{3}$.

A batch processing compact reactor (with a capacity of $10 \mathrm{~m}^{3} /$ batch) can be constructed as a transportable unit. The reactor can be held within a standard shipping container $(2.438 \mathrm{~m}(8 \mathrm{ft})$ wide $\times 2.591 \mathrm{~m}(8.5 \mathrm{ft})$ high $\times 12 \mathrm{~m}(39.5 \mathrm{ft})$ long) or standard high cube shipping container $(2.438 \mathrm{~m}$ $(8 \mathrm{ft})$ wide $\times 2.896 \mathrm{~m}(9.5 \mathrm{ft})$ high $\times 12 \mathrm{~m}(39.5 \mathrm{ft})$ long or $13.556 \mathrm{~m}(44.33 \mathrm{ft}))$, or in a skid-mounted structure with similar dimensions.

This structuring allows a number of reactors to be brought to a location to rapidly provide desalination water. For example, a requirement for $100 \mathrm{~m}^{3} /$ day of irrigation water for a month could be accommodated using four (temporary) reactor units. Each reactor could be operated with an average $4-10 \mathrm{~h}$ batch processing time. The batch processing time required is a function of the chemical complexity of the feed water [2]. The maximum on-site storage requirement for product water in this example is $25 \mathrm{~m}^{3}$. This storage requirement assumes that the product water will be used as irrigation water within $6 \mathrm{~h}$ of production. The storage requirement can be accommodated using a bladder tank, an MDPE (medium density polyethylene) tank, a steel tank, an impoundment or a pond.

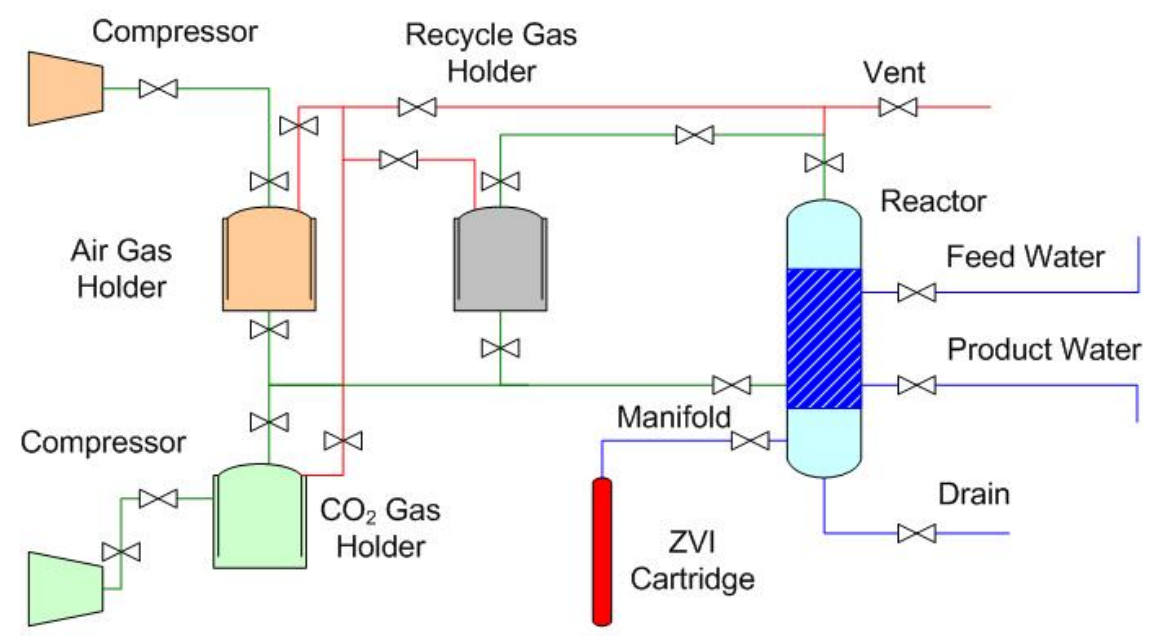

Figure 2. Schematic process flow diagram for a gas-pressured static diffusion ZVI partial desalination reactor.

Each reactor has an expected design life of 20-30 years. The principal consumables are:

1. the periodic replacement of ZVI;

2. the provision of air and the provision of $\mathrm{CO}_{2}$ [2].

These costs vary with source and location. The trial results [2] indicate that maximum gas supply requirements required for this size of compact gas reactor are five cubic feet $/$ minute air $\left(0.135 \mathrm{~m}^{3} / \mathrm{min}\right)$ and 0.8 cubic feet $/$ minute $\mathrm{CO}_{2}\left(0.0229 \mathrm{~m}^{3} / \mathrm{min}\right)$. The air can be provided using compressed air tanks, or low cost electric- or petrol-powered compressors. The $\mathrm{CO}_{2}$ is provided as compressed gas, or from the on-site fermentation of waste cellulose (agricultural) material, or from another source. The product gas can be reused in one or more downstream reactors [1] and can be recycled.

The expected delivered cost of partially-desalinated water from a gas-pressured reactor is a function of location, site-specific requirements, commodity prices, water chemistry, regulatory requirements (environmental, health and safety, agricultural, groundwater, planning, fiscal, etc.), insurance requirements, profit requirements, administrative costs, engineering costs, financing costs and the required levels of desalination [2]. An indicative delivery cost in the order of $\$ 0.01-\$ 0.4 / \mathrm{m}^{3}$ may be achievable using this technology [2]. 


\subsubsection{Stored Product Water}

The product water from gas-pressured reactors (CSD1 [2], E143 [2] and E144 [2] series of trials) showed major changes in $\mathrm{pH}$ in the first 3-6 weeks of storage [2]. The acid or alkaline product water $\mathrm{pH}$ drifted towards a neutral alkalinity $(\mathrm{pH}=7)$ [2]. This change in $\mathrm{pH}$ was accompanied by fluctuations in Eh and EC (electrical conductivity) [2]. Eh, $\mathrm{V}=(2.303 R T / F)\left(-\log \left(\mathrm{e}^{-}\right)\right) . R=$ gas constant; $T=$ Temperature, $\mathrm{K} ; F=$ Faraday Constant; $\mathrm{e}^{-}=$activity of electrons. Eh is measured using an ORP (oxidation reduction potential) probe which has been calibrated to the standard hydrogen electrode using a quinhydrone calibration at $\mathrm{pH}=4$ and $\mathrm{pH}=7$. This study establishes (Appendix $\mathrm{A}$, Tables A1-A11) that these $\mathrm{pH}$, Eh and EC changes do not alter the $\mathrm{Na}^{+}$and $\mathrm{Cl}^{-}$ion concentrations in the stored product water. The trial series notation (CSD1a-CSD1d; E143a-E143k; E144a-E144f) used in reference [2] is retained in this study. Further details are provided in reference [2].

The published product water desalination assessment from gas-pressured static diffusion ZVI partial desalination reactor trials [2] is based on changes in EC [2] and changes in UV-visible absorbance spectra [2]. The UV-visible absorbance spectra [2], redox analyses [1,2] and kinetic analyses [1] have established that the desalination reaction is a redox reaction, which involves at least one reaction step [1,2]. Intermediate $\mathrm{NaCl}$ degradation products $\left(\mathrm{ClO}^{-}, \mathrm{ClO}-\mathrm{OCl}, \mathrm{NaO}^{-}\right)$have been recorded in the nano-particles produced within the reactor during desalination [2].

The $\mathrm{NaCl}$ is either removed permanently by precipitation (reaction route Group A (Appendix B)) or is retained in a different form within the product water (reaction route Group B (Appendix C)).

To date, no ion studies ( $\mathrm{Na}^{+}$and $\mathrm{Cl}^{-}$ions) have been published that demonstrate that the partially-desalinated product water from a gas-pressured static diffusion ZVI partial desalination reactor will remain stable while in storage. The end user for the partially-desalinated water will require assurances that the water will not resalinate, when it is placed in storage or used for irrigation.

This study assesses the stability of stored product water from a gas-pressured reactor, after $1-2.5$ years of storage.

\subsection{Appendices}

This study has a number of appendices that provide data (Appendix A), background information (Appendix B and Appendix C) and expand the discussion of specific aspects of the results, provided in Appendix D-I. The appendices are:

1. Appendix A: Ion Analyses;

2. Appendix B: Summary of Reaction Route A;

3. Appendix C: Summary of Reaction Route B;

4. Appendix D: The Significance of Increased $\mathrm{Na}^{+}$and $\mathrm{Cl}^{-}$Ion Concentrations in the Manifold and ZVI Cartridge (Figures D1 and D2);

5. Appendix E: Location of the Desalination Sites (Figures E1-E5);

6. Appendix F: Nature of the Reacted (Catalytic) ZVI Material (Figures F1-F3);

7. Appendix G: Composition Characteristics of Suitable Saline Water (Figures G1 and G2);

8. Appendix H: Desalination Pathway (Figure H1);

9. Appendix I: Mineralogical Issues (Figures I1 and I2).

\section{Methods and Analysis of Stored Product Water}

Gas-pressured desalination is associated with declines in product water EC (due to desalination) (CSD1, E143, E144 trial series [2]) when the $\mathrm{pH}$ remains stable or decreases within the $\mathrm{pH}$ range of 5-7 during desalination [2]. This study analyses the stability of this product water (Tables A1-A11). 


\subsection{Water Samples}

Two-point-three-litre samples of the feed water and product water from each of the CSD1, E143 and E144 series of trials [2] (21 trials) were collected and placed in sealed MDPE (medium density polyethylene) containers. The feed water sample was collected when the reactor was loaded. The product water sample was collected from the reactor at the conclusion of the individual trial. The EC, Eh and $\mathrm{pH}$ of the water samples at the time of collection are recorded in reference [2]. The containers were then placed in an external, unheated, uninsulated, sheltered environment, where the temperature was allowed to fluctuate with changes in atmospheric temperature, over the range of $-10-25^{\circ} \mathrm{C}$ over a period of $1-2.5$ years.

\subsection{ZVI and Trial Details}

Details of the reactors, ZVI and operating conditions for each of the 21 trials are provided in reference [2]. Each trial series (CSD1, E143, E144 [2]) used a different ZVI charge [2]. The ZVI charge used in the first trial of a series was reused in each subsequent trial in the same series [2].

\subsection{Saline Water Construction}

The CSD1 and E143 trial series (Table 1) used saline water constructed from chemically-pure $\mathrm{NaCl}$ and fresh water [2]. The expected $\mathrm{Na}: \mathrm{Cl}$ molar ratio in the saline feed water is 1.0. Trial series E144 used saline water (Table 1) constructed from road de-icing-grade halite (Zechstein halite from the UK) [28]. Saline water constructed using Zechstein halite is characterized by a $\mathrm{Na}: \mathrm{Cl}$ molar ratio that is less than 1.0 [29]. The lower $\mathrm{Na}: \mathrm{Cl}$ molar ratio results from the presence of $\mathrm{Ca}^{2+}, \mathrm{Mg}^{2+}, \mathrm{Fe}^{\mathrm{n}+}$ and $\mathrm{K}^{+}$ cations in the halite [29]. The halite can also contain $\mathrm{OH}^{-}, \mathrm{HO}_{2}{ }^{-}, \mathrm{CO}_{3}{ }^{2-}, \mathrm{HCO}_{3}{ }^{-}, \mathrm{SO}_{3}{ }^{-}$and $\mathrm{SO}_{4}{ }^{2-}$ anions [29].

Table 1. Salinity of the synthetic saline feed water used in the trials. Data source: Tables A2, A4 and A9.

\begin{tabular}{cccc}
\hline \multirow{2}{*}{ Trial } & \multicolumn{2}{c}{ Feed Water $\left.\mathbf{( g} \cdot \mathbf{L}^{-1}\right)$} & $\mathbf{N a C l}$ \\
\cline { 2 - 4 } & $\mathbf{N a}^{+}$ & $\mathbf{C l}^{-}$ & 2.452 \\
CSD1a & 0.962 & 1.489 & 2.452 \\
CSD1b & 0.962 & 1.489 & 2.570 \\
CSD1c & 1.009 & 1.562 & 2.943 \\
CSD1d & 1.155 & 1.788 & 6.021 \\
E143a & 2.363 & 3.658 & 4.660 \\
E143b & 1.829 & 2.831 & 5.049 \\
E143c & 1.982 & 3.067 & 5.632 \\
E143d & 2.210 & 3.422 & 6.799 \\
E143e & 2.668 & 4.130 & 1.939 \\
E143f & 0.761 & 1.178 & 2.722 \\
E143g & 1.068 & 1.653 & 2.722 \\
E143h & 1.068 & 1.653 & 3.105 \\
E143i & 1.219 & 1.886 & 3.580 \\
E143j & 1.405 & 2.175 & 4.039 \\
E143k & 1.585 & 2.454 & 3.904 \\
E144a & 1.134 & 2.770 & 4.237 \\
E144b & 1.312 & 2.925 & 2.462 \\
E144c & 0.636 & 1.826 & 2.002 \\
E144d & 0.522 & 1.480 & 2.219 \\
E144e & 0.512 & 1.707 & 10.680 \\
E144f & 4.161 & 6.519 &
\end{tabular}

The fresh water used to construct the synthetic saline water was natural spring water derived from a private water supply in Dunning, Ochil Hills, Scotland [2]. The groundwater is extracted from a fractured Devonian, Old Red Sandstone volcanic series aquifer (fractured andesites, fractured 
dacites, fractured pyroclastics, (Dunning, Perthshire, UK). A typical ion composition is [2]: Anions: $\mathrm{Cl}=11.67 \mathrm{mg} \cdot \mathrm{L}^{-1} ; \mathrm{N}\left(\mathrm{NO}_{3}\right)=11.28 \mathrm{mg} \cdot \mathrm{L}^{-1} ; \mathrm{S}\left(\mathrm{SO}_{4}\right)=4.16 \mathrm{mg} \cdot \mathrm{L}^{-1} ; \mathrm{P}\left(\mathrm{PO}_{4}\right) \leqslant 0.10 \mathrm{mg} \cdot \mathrm{L}^{-1}$; $\mathrm{F}=0.024 \mathrm{mg} / \mathrm{L} ; \mathrm{N}\left(\mathrm{NO}_{2}\right)=0.04 \mathrm{mg} \cdot \mathrm{L}^{-1} ; \mathrm{HCO}_{3}{ }^{-} / \mathrm{CO}_{3}{ }^{2-} \leqslant 10 \mathrm{mg} \cdot \mathrm{L}^{-1}$; Cations: $\mathrm{K}=1.69 \mathrm{mg} \cdot \mathrm{L}^{-1}$; $\mathrm{Ca}=32.91 \mathrm{mg} \cdot \mathrm{L}^{-1} ; \mathrm{Na}=6.32 \mathrm{mg} \cdot \mathrm{L}^{-1} ; \mathrm{Al} \leqslant 150.0 \mu \mathrm{g} \cdot \mathrm{L}^{-1} ; \mathrm{Fe} \leqslant 30.0 \mu \mathrm{g} \cdot \mathrm{L}^{-1} ; \mathrm{Mn}=1.70 \mu \mathrm{g} \cdot \mathrm{L}^{-1}$; $\mathrm{P} \leqslant 0.005 \mathrm{mg} \cdot \mathrm{L}^{-1} ; \mathrm{S}=4.31 \mathrm{mg} \cdot \mathrm{L}^{-1} ; \mathrm{B}=29.40 \mu \mathrm{g} \cdot \mathrm{L}^{-1} ; \mathrm{Ba}=135.60 \mu \mathrm{g} \cdot \mathrm{L}^{-1} ; \mathrm{Cd} \leqslant 0.2 \mu \mathrm{g} \cdot \mathrm{L}^{-1}$; $\mathrm{Co} \leqslant 0.2 \mu \mathrm{g} \cdot \mathrm{L}^{-1} ; \mathrm{Cr} \leqslant 0.2 \mu \mathrm{g} \cdot \mathrm{L}^{-1} ; \mathrm{Cu}=77.7 \mu \mathrm{g} \cdot \mathrm{L}^{-1} ; \mathrm{Ni} \leqslant 3 \mu \mathrm{g} \cdot \mathrm{L}^{-1} ; \mathrm{Pb} \leqslant 10 \mu \mathrm{g} \cdot \mathrm{L}^{-1}$; $\mathrm{Si}=5.21 \mathrm{mg} \cdot \mathrm{L}^{-1} ; \mathrm{Sr}=144.9 \mu \mathrm{g} \cdot \mathrm{L}^{-1} ; \mathrm{Zn}=37.4 \mu \mathrm{g} \cdot \mathrm{L}^{-1} ;$ As $\leqslant 5 \mu \mathrm{g} \cdot \mathrm{L}^{-1} ;$ Mo $\leqslant 20 \mu \mathrm{g} \cdot \mathrm{L}^{-1}$; $\mathrm{Se} \leqslant 20 \mu \mathrm{g} \cdot \mathrm{L}^{-1} ; \mathrm{Sn} \leqslant 20 \mu \mathrm{g} \cdot \mathrm{L}^{-1} ; \mathrm{Sb} \leqslant 10 \mu \mathrm{g} \cdot \mathrm{L}^{-1}$. This water analysis is reproduced from reference [2].

ZVI desalination studies have historically either used synthetic saline water constructed using chemically-pure $\mathrm{NaCl}[1,2,5]$ or saline water constructed using Zechstein halite [2-4]. The use of chemically-pure $\mathrm{NaCl}$ creates a simple chemical environment (e.g., $\mathrm{H}_{2} \mathrm{O}+\mathrm{Fe}^{0}+\mathrm{Na}^{+}+\mathrm{Cl}^{-}$), which allows directional changes to be easily identified (e.g., linkage of salinity decline to measures, such as $\mathrm{EC}$ reduction [1,2]). The use of Zechstein halite creates a more complex water, where reductions in salinity can be associated with increases in EC [2,3], and the initial molar ratio of $\mathrm{Na}: \mathrm{Cl}$ is rarely 1:1 [29]. In complex saline water, desalination is recognized using either UV-visible absorbance spectroscopy [2] or ion analyses [3].

\subsection{Salinity Measurement}

The ion concentrations in the stored water samples were analysed using $\mathrm{Cl}^{-}$ion and $\mathrm{Na}^{+}$ ion selective electrodes and ion meters manufactured by Bante Instrument Ltd., Shanghai, China (Model 931).

The salinity values associated with the ion selective electrodes were calibrated (in accordance with the manufacturer's instructions) using a four-point molar calibration $\left(0.001,0.01,0.1,1.0\right.$ moles $\left.\mathrm{L}^{-1}\right)$ for both $\mathrm{Cl}^{-}$and $\mathrm{Na}^{+}$ions. Calibration and measurements were undertaken at the same temperature.

\section{Results}

The ion analyses for the stored water are provided in Appendix A as follows: (i) Trials CSD1a-CSD1d: Tables A1 and A2; storage time: 2-2.5 years; (ii) Trials E143a-E143k, Tables A3-A7; storage time: 18-24 months; (iii) Trials E144a-E144f, Tables A8-A11; storage time: 12-18 months.

\subsection{Principal Operating Differences between Trial Series CSD1, E143, E144}

The Trial Series CSD1 assessed the operation of the desalination process over the temperature range of $20-55^{\circ} \mathrm{C}$. Trial Series E143 repeated the desalination process over the temperature range of $0-25{ }^{\circ} \mathrm{C}$. Trial series E144 repeated the E143 series of trials using chemically-complex saline water (constructed using halite).

\subsection{Initial Salinity Calculation Approach in Trial Series CSD1, E143, E144}

The feed water and product water salinity for Trial Series CSD1, E143 and E144 was initially calculated from EC [2] using the regression equation [2]:

$$
\text { Salinity, } \mathrm{g} \cdot \mathrm{L}^{-1}=0.5401 \mathrm{EC}\left(\mathrm{mS} \cdot \mathrm{cm}^{-1}\right)-0.1
$$

The feed water EC was measured when the water was placed in the reactor [2]. The product water EC was measured when the water was extracted from the reactor [2].

The general regression equation [2]:

$$
\left(\text { Salinity, } \mathrm{g} \cdot \mathrm{L}^{-1}=\{F\} \mathrm{EC}\left(\mathrm{mS} \cdot \mathrm{cm}^{-1}\right)\right)
$$

is widely used as a measure of salinity assessment [2]. $\{F\}$ is commonly in the range of $0.5-0.55$ for pure $\mathrm{NaCl}$ and decreases in pure $\mathrm{NaCl}: \mathrm{H}_{2} \mathrm{O}$ solutions with increasing temperature (as EC increases 
with temperature) [2]. $\{F\}$ increases in high salinity chemically-impure saline solutions, e.g., [1], and can fall below 0.5 in some circumstances. A graphical plot of measured EC vs. measured salinity $\left(\mathrm{Na}^{+}+\mathrm{Cl}^{-}\right.$ions) will show a strong regression relationship [1,2].

\subsection{Observed Stored Water Salinities for Trial Series CSD1, E143, E144}

Figure 1 provides the salinity measurements based on EC at the time the water was extracted from the reactor and the salinity measurements based on direct ion analysis following 1-2.5 years of storage. The regression analyses (Figure 3) establish that:

1. EC analyses provide a reasonable estimate of feed water salinity when the saline water is constructed from chemically-pure $\mathrm{NaCl}$ (Figure 3a), i.e., $\{F\}$ approximates to 0.54;

2. EC analyses can underestimate the salinity of feed water, when the feed water is constructed using halite (E144 Trial Series) (Figure 3a), i.e., $\{F\}$ is greater than 0.54;

3. EC analyses provide a reasonable indication of product water salinity. The regression correlation indicates that the product water salinity has remained unchanged while the samples were held in storage (Figure $3 b$ );

4. Decreases in salinity based on EC may underestimate the actual change in salinity by about $10 \%$ (Figure 3c);

5. The molar Na:Cl ratio in the feed water from the CSD1 and E143 series trials approximates to 1.0 (Figure 3d). The molar Na:Cl ratio of the feed water from the E144 series trials (Figure 3d) falls within the range of $0.46-0.99$;

6. The product water molar $\mathrm{Na}: \mathrm{Cl}$ ratios indicate that preferential removal of $\mathrm{Na}^{+}$ions (relative to $\mathrm{Cl}^{-}$ions) can occur (and vice versa) during the desalination process (Figure 3d).

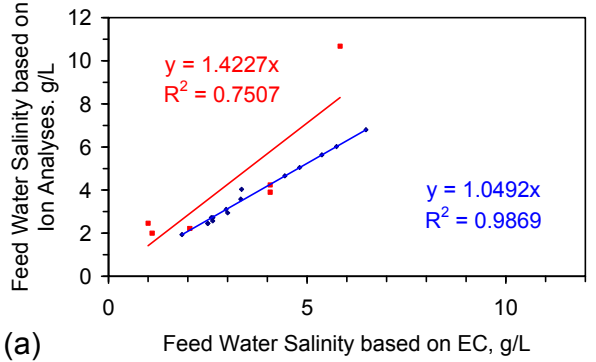

(a)

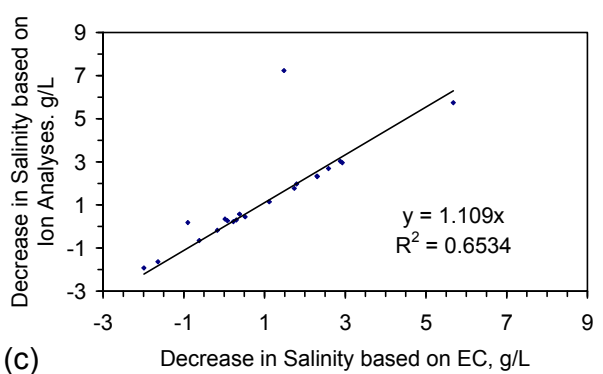

(c)

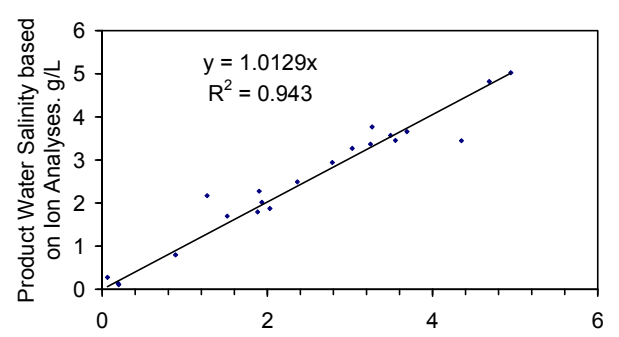

(b)



Figure 3. Comparison of trial results made using electrical conductivity (EC) when the water was extracted from the reactor and using direct ion analysis following 1-2.5 years of storage. (a) Feed water. Red markers = E144 trial series. Blue markers = CSD1 and E143 trial series; (b) Product water; (c) Decrease in salinity based on EC when the water was removed from the reactor $v$ s. decrease in salinity based on direct ion analyses of the feed and product water following 1-2.5 years of storage; (d) Na:Cl molar ratio, feed water vs. product water. Red markers = E144 trial series. Blue markers = CSD1 and E143 trial series; arrows indicate where the number of moles of $\mathrm{Na}^{+}$removed exceeds the number of moles of $\mathrm{Cl}^{-}$removed, and vice versa. Data sources: (i) ion data: Tables A1-A11; (ii) EC data: [2]. Further details associated with salinity assessment using EC are provided in reference [2]. 


\section{Discussion}

The results (Figure 3, Tables A1-A11) demonstrate that the removed $\mathrm{Na}^{+}$and $\mathrm{Cl}^{-}$ions are irreversibly held on either the ZVI, or on a ZVI corrosion product, or are retained in the reactor in the manifold, or ZVI cartridge. The results are consistent with the $\mathrm{NaCl}$ being removed using reaction route A (Appendix B). They do not preclude the presence of intermediate reactions associated with reaction route $\mathrm{B}$ (Appendix $\mathrm{C}$ ). The results establish that $\mathrm{NaCl}$ is preferentially removed from the bulk of the water body and is concentrated in the manifold and reactor cartridge (Table A6). This concentration is associated with preferential removal of $\mathrm{Na}^{+}$ions from the bulk of the water in the reactor. The significance of this observation is discussed further in Appendix D, Appendix E, Appendix F, Appendix G, Appendix H and Appendix I.

The mechanism for desalination appears to contain elements that are consistent with both reaction group A (Appendix B) and reaction group B (Appendix C). The reaction is not a simple pseudo-first order reaction [1] and appears to contain a number of stages [1]. The reaction is electrochemical [1-5] and is associated with a measurable capacitance in the ZVI [2].

Acid gases $\left(\mathrm{CO}, \mathrm{CO}_{2}\right)$, reducing gases $\left(\mathrm{H}_{2}, \mathrm{CH}_{4}\right)$ and oxidizing gases $\left(\mathrm{O}_{2}\right)$ have been demonstrated to be effective in ZVI desalination [2]. This study has demonstrated (Tables A1-A11) by using two widely-available and low cost gases $\left(\mathrm{CO}_{2}\right.$ and air $)$ in the desalination process that it is possible to:

1. accelerate the rate of ZVI desalination to allow small compact units to be used to produce the product water;

2. produce a product water that is stable when placed in storage;

3. adjust the $\mathrm{Na}: \mathrm{Cl}$ molar ratio in the product water to optimize irrigation water quality and maximize crop yields.

The manipulation of temperature, reactor pressure, gas saturation and gas composition is demonstrated to have the potential to create (by utilizing Nernst theory [27]) a commercial reactor unit, which can actively control: (i) the rate of desalination (time taken to achieve $t_{B S}$ ); (ii) the base salinity $\left(B_{S}\right)$ of the product water; and (iii) the $\mathrm{Na}: \mathrm{Cl}$ molar ratio in the product water.

\section{Conclusions}

This study has used direct ion analyses (Figure 3, Tables A1-A11) to confirm that the product water from a gas-pressured ZVI desalination reactor maintains a stable salinity in storage over a period of 1-2.5 years. The demonstration of product water stability is an essential pre-requisite for any commercial development of this desalination technology. The ion analyses have demonstrated $\mathrm{Na}^{+}$ ion removal of up to $99 \%$ (e.g., Trial E143a, feed water contained $2.363 \mathrm{~g} \mathrm{Na}^{+} \cdot \mathrm{L}^{-1}$ ). This demonstrates that the desalination process will be able to improve the quality of irrigation water.

The ability (Figure 1) of this technology to preferentially remove $\mathrm{Na}^{+}$ions relative to $\mathrm{Cl}^{-}$ions (and vice versa) has important agricultural implications. It establishes that ZVI desalination could be used to provide irrigation water from saline sources in order to boost the yield of specific crops [2].

The demonstration of higher rates of $\mathrm{Na}^{+}$removal, relative to $\mathrm{Cl}^{-}$removal, in an oxygenated environment (Figure 1, Tables A1-A11) is consistent with a catalytic model (Appendix F), where (during discharge reactions ( $\mathrm{pH}$ increase) $) \mathrm{Na}^{+}$ions react with derivatives from the pressurizing gas to effect removal. The galvanic charge-discharge model for ZVI desalination (and corrosion) provides a practical basis for the acceleration of ZVI desalination and the manipulation of the composition of the ZVI desalination product.

The next major stage required in the commercial development of this gas-pressured ZVI desalination technology is the testing (including independent verification and regulatory verification) of a commercial scale (transportable) batch reactor unit with a capacity in the range of $5-30 \mathrm{~m}^{3} /$ water batch (producing 500-30,000 $\mathrm{m}^{3}$ /a of partially-desalinated water).

Acknowledgments: This study was funded by DCA Consultants Ltd. 
Conflicts of Interest: The author declares no conflict of interest.

\section{Appendix A: Tables of Data and Ion Analyses}

Table A1. CSD1 trial's basic data. ZVI $=26.66 \mathrm{~g} \cdot \mathrm{L}^{-1}$ [2]. Reactor capacity $=8.4 \mathrm{~L}$. Trials CSD1a-CSD1d were pressurized ( $<0.1 \mathrm{MPa}$ ) with air [2]. Trial CSD1d included pressurization by $20 \% \mathrm{CO}_{2}+80 \% \mathrm{~N}_{2}$ [2] . Batch operation, air flow $=1.3-3.8 \mathrm{~L} \cdot \mathrm{h}^{-1} \cdot \mathrm{CO}_{2}$ flow $=0.18 \mathrm{~L} \cdot \mathrm{h}^{-1}$. Pressure $=$ atmospheric $+0.01 \mathrm{MPa}$; Non-isothermal temperature $=10-50{ }^{\circ} \mathrm{C}$; reactor capacity $=8.4 \mathrm{~L}$; reactor: Figure 2; feed water constructed using NaCl; CSD ZVI cartridge [2]; cartridge diameter $=20 \mathrm{~mm}$; manifold diameter $=40 \mathrm{~mm}$; energy usage $\leqslant 0.18 \mathrm{~kW} \cdot \mathrm{m}^{-3}$ (during air flows); further details are provided in reference [2].

\begin{tabular}{ccc}
\hline Trial & Maximum Temperature $\left({ }^{\circ} \mathbf{C}\right)$ & Duration (h) \\
\hline CSD1a & 50 & 15 \\
CSD1b & 44 & 124 \\
CSD1c & 39 & 30 \\
CSD1d & 36 & 11 \\
\hline
\end{tabular}

Table A2. Ion measurements for the CSD1 trials. $\mathrm{NaCl}=\mathrm{Na}^{+}+\mathrm{Cl}^{-}$.

\begin{tabular}{ccccccc}
\hline \multirow{2}{*}{ Trial } & \multicolumn{2}{c}{ Feed Water $\left(\mathbf{g} \cdot \mathbf{L}^{-1}\right)$} & \multicolumn{3}{c}{ Product Water $\left(\mathbf{g} \cdot \mathbf{~ L}^{-1}\right)$} \\
\cline { 2 - 7 } & $\mathbf{N a}^{+}$ & $\mathbf{C l}$ & $\mathbf{N a C l}$ & $\mathbf{N a}^{+}$ & $\mathbf{C l}^{-}$ & $\mathbf{N a C l}$ \\
\hline CSD1a & 0.962 & 1.489 & 2.452 & 0.005 & 0.131 & 0.136 \\
CSD1b & 0.962 & 1.489 & 2.452 & 0.004 & 0.104 & 0.108 \\
CSD1c & 1.009 & 1.562 & 2.570 & 0.173 & 0.625 & 0.799 \\
CSD1d & 1.155 & 1.788 & 2.943 & 0.545 & 1.251 & 1.796 \\
\hline
\end{tabular}

Table A3. E143 series trials. Data source: [2]. Batch operation, air flow $=13.2 \mathrm{~L} \cdot \mathrm{h}-1 \cdot \mathrm{CO}_{2}$ flow $=3.3 \mathrm{~L} \cdot \mathrm{h}^{-1}$. Pressure $=$ atmospheric $+0.01 \mathrm{MPa}$; non-isothermal temperature $=5-12{ }^{\circ} \mathrm{C}$; reactor capacity $=5.8 \mathrm{~L}$; reactor: Figure 2; feed water constructed using $\mathrm{NaCl}$; E143 ZVI cartridge [2]; cartridge diameter $=20 \mathrm{~mm}$; manifold diameter $=40 \mathrm{~mm}$; energy usage $\leqslant 0.18 \mathrm{~kW} \cdot \mathrm{m}^{-3}$ (during air flows); further details are provided in reference [2].

\begin{tabular}{ccccc}
\hline Trial & $\begin{array}{c}\text { Feed Water } \\
\text { Volume (L) }\end{array}$ & $\begin{array}{c}\text { Product Water } \\
\text { Volume (L) }\end{array}$ & Duration (h) & $\begin{array}{c}\text { Air Flow Duration } \\
\text { (\%) }\end{array}$ \\
\hline E143a & 5.8 & 5.0 & 9.00 & $100.0 \%$ \\
E143b & 5.8 & 5.0 & 8.33 & $60.6 \%$ \\
E143c & 5.8 & 5.1 & 4.37 & $58.6 \%$ \\
E143d & 5.8 & 5.1 & 4.02 & $43.8 \%$ \\
E143e & 5.8 & 5.1 & 3.87 & $44.2 \%$ \\
E143f & 5.8 & 5.2 & 2.70 & $100.0 \%$ \\
E143g & 5.8 & 5.0 & 3.08 & $100.0 \%$ \\
E143h & 5.8 & 4.3 & 14.30 & $100.0 \%$ \\
E143i & 5.8 & 4.4 & 8.90 & $50.6 \%$ \\
E143j & 5.8 & 4.3 & 7.50 & $29.3 \%$ \\
E143k & 5.8 & 4.3 & 3.58 & $72.1 \%$ \\
\hline
\end{tabular}

Table A4. Ion measurements for the E143 trial series. $\mathrm{NaCl}=\mathrm{Na}^{+}+\mathrm{Cl}^{-}$.

\begin{tabular}{ccccccc}
\hline \multirow{2}{*}{ Trial } & \multicolumn{7}{c}{ Feed Water $\left(\mathbf{g} \cdot \mathbf{L}^{-1}\right)$} & \multicolumn{3}{c}{ Product Water $\left(\mathbf{g} \cdot \mathbf{L}^{-1}\right)$} \\
\cline { 2 - 7 } & $\mathbf{N a}^{+}$ & $\mathbf{C l}^{-}$ & $\mathbf{N a C l}$ & $\mathbf{N a}^{+}$ & $\mathbf{C l}^{-}$ & $\mathbf{N a C l}$ \\
\hline E143a & 2.363 & 3.658 & 6.021 & 0.024 & 0.255 & 0.279 \\
E143b & 1.829 & 2.831 & 4.660 & 0.497 & 1.201 & 1.698 \\
\hline
\end{tabular}


Table A4. Cont.

\begin{tabular}{ccccccc}
\hline \multirow{2}{*}{ Trial } & \multicolumn{3}{c}{ Feed Water $\left(\mathbf{g} \cdot \mathbf{~ L}^{-1}\right)$} & \multicolumn{3}{c}{ Product Water $\left(\mathbf{g} \cdot \mathbf{L}^{-1}\right)$} \\
\cline { 2 - 7 } & $\mathbf{N a}^{+}$ & $\mathbf{C l}$ & $\mathbf{N a C l}$ & $\mathbf{N a}^{+}$ & $\mathbf{C l}^{-}$ & $\mathbf{N a C l}$ \\
\hline E143c & 1.982 & 3.067 & 5.049 & 0.617 & 1.403 & 2.020 \\
E143d & 2.210 & 3.422 & 5.632 & 1.001 & 1.940 & 2.942 \\
E143e & 2.668 & 4.130 & 6.799 & 1.837 & 2.985 & 4.821 \\
E143f & 0.761 & 1.178 & 1.939 & 1.294 & 2.277 & 3.570 \\
E143g & 1.068 & 1.653 & 2.722 & 0.784 & 1.709 & 2.494 \\
E143h & 1.068 & 1.653 & 2.722 & 1.171 & 2.199 & 3.370 \\
E143i & 1.219 & 1.886 & 3.105 & 1.961 & 3.064 & 5.026 \\
E143j & 1.405 & 2.175 & 3.580 & 1.123 & 2.147 & 3.270 \\
E143k & 1.585 & 2.454 & 4.039 & 0.784 & 2.985 & 3.769 \\
\hline
\end{tabular}

Table A5. Product water ion measurements adjusted for water loss/consumption for the E143 trial series. $\mathrm{NaCl}=\mathrm{Na}^{+}+\mathrm{Cl}^{-}$.

\begin{tabular}{ccccccc}
\hline \multirow{2}{*}{ Trial } & \multicolumn{2}{c}{ Product Water (Adjusted for Water Loss) $\mathbf{( g \cdot \mathbf { L } ^ { - 1 } )}$} & \multicolumn{2}{c}{ Net Ion Removal $\mathbf{~ ( g \cdot \mathbf { ~ } ^ { - 1 } )}$} \\
\cline { 2 - 6 } & $\mathbf{N a}^{+}$ & $\mathbf{C l}$ & $\mathbf{N a C l}$ & $\mathbf{N a}^{+}$ & $\mathbf{C l}^{-}$ & $\mathbf{N a C l}$ \\
\hline E143a & 0.0207 & 0.2198 & 0.2405 & 2.342 & 3.438 & 5.780 \\
E143b & 0.4284 & 1.0353 & 1.4638 & 1.401 & 1.796 & 3.196 \\
E143c & 0.5425 & 1.2337 & 1.7762 & 1.439 & 1.833 & 3.273 \\
E143d & 0.8802 & 1.7059 & 2.5869 & 1.330 & 1.716 & 3.045 \\
E143e & 1.6153 & 2.6247 & 4.2392 & 1.053 & 1.505 & 2.560 \\
E143f & 1.1490 & 2.0218 & 3.1699 & -0.388 & -0.844 & -1.231 \\
E143g & 0.6759 & 1.4733 & 2.1500 & 0.392 & 0.180 & 0.572 \\
E143h & 0.8682 & 1.6303 & 2.4984 & 0.200 & 0.023 & 0.224 \\
E143i & 1.4877 & 2.3244 & 3.8128 & -0.269 & -0.438 & -0.708 \\
E143j & 0.8326 & 1.5917 & 2.4243 & 0.572 & 0.583 & 1.156 \\
E143k & 0.5812 & 2.2130 & 2.7943 & 1.004 & 0.241 & 1.245 \\
\hline
\end{tabular}

Table A6. Trial E143k: ion concentrations. The manifold water (0.3 L) and ZVM cartridge water (0.1 L) are described further in reference [2].

\begin{tabular}{ccccc}
\hline Item & $\mathbf{N a}\left(\mathbf{g} \cdot \mathbf{L}^{-1}\right)$ & $\mathbf{C l}\left(\mathbf{g} \cdot \mathbf{~ L}^{-1}\right)$ & $\mathbf{N a C l}\left(\mathbf{g} \cdot \mathbf{~ L}^{-1}\right)$ & Na:Cl Molar Ratio \\
\hline Feed Water & 1.585 & 2.454 & 4.039 & 1.000 \\
Product Water & 0.784 & 2.985 & 3.769 & 0.407 \\
Manifold Water & 13.653 & 14.966 & 28.620 & 0.912 \\
ZVI Cartridge & 446.678 & 144.185 & $590.862 *$ & 3.098 \\
$\quad$ Water & & & & \\
\hline
\end{tabular}

Note: * includes $\mathrm{NaOH}$ and related species.

Table A7. Trial E143 series: comparison of trial analyses made in 2014 (based on EC [2]) and 2015 (Tables A3-A6).

\begin{tabular}{|c|c|c|c|c|c|c|c|c|}
\hline \multirow[t]{2}{*}{ Trial } & \multicolumn{2}{|c|}{ Analyses Based on EC } & \multicolumn{2}{|c|}{ Direct Ion Analyses } & \multicolumn{2}{|c|}{$\mathrm{NaCl}$ Removed $\left(\mathrm{g} \cdot \mathrm{L}^{-1}\right)$} & \multicolumn{2}{|c|}{$\begin{array}{l}\mathrm{NaCl} \text { Removed * } \\
\left(\mathrm{g} \cdot \mathrm{L}^{-1}\right)\end{array}$} \\
\hline & $\begin{array}{c}\text { Feed } \\
\text { Water } \\
\left(\mathrm{g} \cdot \mathrm{L}^{-1}\right)\end{array}$ & $\begin{array}{l}\text { Product } \\
\text { Water } \\
\left(\mathrm{g} \cdot \mathbf{L}^{-1}\right)\end{array}$ & $\begin{array}{c}\text { Feed } \\
\text { Water } \\
\left(\mathrm{g} \cdot \mathrm{L}^{-1}\right)\end{array}$ & $\begin{array}{l}\text { Product } \\
\text { Water } \\
\left(\mathrm{g} \cdot \mathrm{L}^{-1}\right)\end{array}$ & $\begin{array}{c}\text { EC } \\
\text { Analyses }\end{array}$ & $\begin{array}{c}\text { Ion } \\
\text { Analyses }\end{array}$ & $\begin{array}{c}\text { EC } \\
\text { Analyses }\end{array}$ & $\begin{array}{c}\text { Ion } \\
\text { Analyses }\end{array}$ \\
\hline E143a & 5.74 & 0.06 & 6.02 & 0.28 & 5.68 & 5.74 & 5.688 & 5.780 \\
\hline E143b & 4.44 & 1.51 & 4.66 & 1.70 & 2.93 & 2.96 & 3.138 & 3.196 \\
\hline E143c & 4.81 & 1.93 & 5.05 & 2.02 & 2.88 & 3.03 & 3.113 & 3.273 \\
\hline E143d & 5.37 & 2.79 & 5.63 & 2.94 & 2.58 & 2.69 & 2.917 & 3.045 \\
\hline
\end{tabular}


Table A7. Cont.

\begin{tabular}{|c|c|c|c|c|c|c|c|c|}
\hline \multirow[t]{2}{*}{ Trial } & \multicolumn{2}{|c|}{ Analyses Based on EC } & \multicolumn{2}{|c|}{ Direct Ion Analyses } & \multicolumn{2}{|c|}{ NaCl Removed (g. $\left.\mathbf{L}^{-1}\right)$} & \multicolumn{2}{|c|}{$\begin{array}{l}\text { NaCl Removed * } \\
\left(\mathrm{g} \cdot \mathrm{L}^{-1}\right)\end{array}$} \\
\hline & $\begin{array}{c}\text { Feed } \\
\text { Water } \\
\left(\mathrm{g} \cdot \mathbf{L}^{-1}\right)\end{array}$ & $\begin{array}{l}\text { Product } \\
\text { Water } \\
\left(\mathrm{g} \cdot \mathrm{L}^{-1}\right)\end{array}$ & $\begin{array}{c}\text { Feed } \\
\text { Water } \\
\left(\mathrm{g} \cdot \mathbf{L}^{-1}\right)\end{array}$ & $\begin{array}{l}\text { Product } \\
\text { Water } \\
\left(\mathrm{g} \cdot \mathrm{L}^{-1}\right)\end{array}$ & $\begin{array}{c}\text { EC } \\
\text { Analyses }\end{array}$ & $\begin{array}{c}\text { Ion } \\
\text { Analyses }\end{array}$ & $\begin{array}{c}\text { EC } \\
\text { Analyses }\end{array}$ & $\begin{array}{c}\text { Ion } \\
\text { Analyses }\end{array}$ \\
\hline E143e & 6.48 & 4.69 & 6.8 & 4.82 & 1.79 & 1.98 & 2.356 & 2.560 \\
\hline E143h & 2.63 & 3.25 & 2.72 & 3.37 & -0.62 & -0.65 & 0.221 & 0.224 \\
\hline E143i & 2.96 & 4.95 & 3.11 & 5.03 & -1.99 & -1.92 & -0.795 & -0.708 \\
\hline E143j & 3.33 & 3.03 & 3.58 & 3.27 & 0.30 & 0.31 & 1.084 & 1.156 \\
\hline E143k & 3.35 & 3.27 & 4.04 & 3.77 & 0.08 & 0.27 & 0.926 & 1.245 \\
\hline
\end{tabular}

Table A8. E144 series trials. Details of each reactor and ZVI are provided in reference [2]. The difference in water volume between the feed water and product water volumes is primarily a result of the reaction of the $\mathrm{ZVI}$ with the water, but may include some water removed by the pressurizing gas (air, or $20 \% \mathrm{CO}_{2}+80 \% \mathrm{~N}_{2}$ ) [2]. Batch operation, air flow $=13.2 \mathrm{~L} \cdot \mathrm{h}^{-1} \cdot \mathrm{CO}_{2}$ flow $=3.3 \mathrm{~L} \cdot \mathrm{h}^{-1}$. Pressure $=$ atmospheric $+0.01 \mathrm{MPa}$; non-isothermal temperature $=5-19{ }^{\circ} \mathrm{C}$; reactor capacity $=5.8 \mathrm{~L}$; reactor: Figure 2; feed water constructed using Zechstein Halite; E144 ZVI cartridge [2]; cartridge diameter $=20 \mathrm{~mm}$; manifold diameter $=40 \mathrm{~mm}$; energy usage $\leqslant 0.18 \mathrm{~kW} \cdot \mathrm{m}^{-3}$ (during air flows); further details are provided in reference [2].

\begin{tabular}{ccccc}
\hline Trial & $\begin{array}{c}\text { Feed Water } \\
\text { Volume (L) }\end{array}$ & $\begin{array}{c}\text { Product Water } \\
\text { Volume (L) }\end{array}$ & Duration (h) & $\begin{array}{c}\text { Air Flow Duration } \\
\text { (\%) }\end{array}$ \\
\hline E144a & 5.8 & 4.4 & 6.48 & $58.64 \%$ \\
E144b & 5.8 & 4.4 & 104.30 & $67.59 \%$ \\
E144c & 5.8 & 4.9 & 690.00 & $0.00 \%$ \\
E144d & 5.8 & 4.6 & 291.00 & $0.00 \%$ \\
E144e & 5.8 & 4.4 & 537.00 & $0.00 \%$ \\
E144f & 5.8 & 3.9 & 1295.00 & $0.00 \%$ \\
\hline
\end{tabular}

Table A9. Ion measurements for the E144 trial series. $\mathrm{NaCl}=\mathrm{Na}^{+}+\mathrm{Cl}^{-}$.

\begin{tabular}{ccccccc}
\hline \multirow{2}{*}{ Trial } & \multicolumn{2}{c}{ Feed Water $\left(\mathbf{g} \cdot \mathbf{L}^{-1}\right)$} & \multicolumn{4}{c}{ Product Water $\mathbf{( g \cdot \mathbf { L } ^ { - 1 } )}$} \\
\cline { 2 - 7 } & $\mathbf{N a}^{+}$ & $\mathbf{C l}$ & $\mathbf{N a C l}$ & $\mathbf{N a}^{+}$ & $\mathbf{C l}^{-}$ & $\mathbf{N a C l}$ \\
\hline E144a & 1.134 & 2.770 & 3.904 & 1.074 & 2.381 & 3.455 \\
E144b & 1.312 & 2.925 & 4.237 & 1.123 & 2.537 & 3.660 \\
E144c & 0.636 & 1.826 & 2.462 & 0.593 & 1.684 & 2.276 \\
E144d & 0.522 & 1.480 & 2.002 & 0.593 & 1.582 & 2.174 \\
E144e & 0.512 & 1.707 & 2.219 & 0.497 & 1.378 & 1.875 \\
E144f & 4.161 & 6.519 & 10.680 & 1.196 & 2.251 & 3.446 \\
\hline
\end{tabular}

Table A10. Product water ion measurements adjusted for water loss/consumption for the E144 trial series.

\begin{tabular}{|c|c|c|c|c|c|c|}
\hline \multirow{2}{*}{ Trial } & \multicolumn{3}{|c|}{ Product Water (Adjusted for Water Loss) $\left(g \cdot \mathbf{L}^{-1}\right)$} & \multicolumn{2}{|c|}{ Net Ion Removal (g. $\mathrm{L}^{-1}$ ) } & \multirow[b]{2}{*}{$\mathrm{NaCl}$} \\
\hline & $\mathrm{Na}^{+}$ & $\mathrm{Cl}^{-}$ & $\mathrm{NaCl}$ & $\mathrm{Na}^{+}$ & $\mathrm{Cl}^{-}$ & \\
\hline E144a & 0.8148 & 1.8063 & 2.6210 & 0.319 & 0.964 & 1.283 \\
\hline E144b & 0.8519 & 1.9246 & 2.7766 & 0.460 & 1.000 & 1.460 \\
\hline $\mathrm{E} 144 \mathrm{c}$ & 0.5010 & 1.4227 & 1.9228 & 0.135 & 0.403 & 0.539 \\
\hline E144d & 0.4652 & 1.2411 & 1.7055 & 0.057 & 0.239 & 0.297 \\
\hline E144e & 0.3770 & 1.0454 & 1.4224 & 0.135 & 0.662 & 0.797 \\
\hline E144f & 0.8042 & 1.5136 & 2.3171 & 3.357 & 5.005 & 8.363 \\
\hline
\end{tabular}


Table A11. Trial E144 series: comparison of trial analyses. Data source for EC analyses: [2].

\begin{tabular}{|c|c|c|c|c|c|c|}
\hline \multirow{2}{*}{ Trial } & \multicolumn{2}{|c|}{ Trial Analyses Based on EC } & \multicolumn{2}{|c|}{ Direct Ion Analyses } & \multicolumn{2}{|c|}{$\mathrm{NaCl}$ Removed (g. $\mathrm{L}^{-1}$ ) } \\
\hline & $\begin{array}{l}\text { Feed Water } \\
\left(\mathrm{g} \cdot \mathrm{L}^{-1}\right)\end{array}$ & $\begin{array}{l}\text { Product Water } \\
\left(\mathrm{g} \cdot \mathrm{L}^{-1}\right)\end{array}$ & $\begin{array}{l}\text { Feed Water } \\
\left(\mathrm{g} \cdot \mathbf{L}^{-1}\right)\end{array}$ & $\begin{array}{l}\text { Product Water } \\
\quad\left(\mathrm{g} \cdot \mathbf{L}^{-1}\right)\end{array}$ & EC Analyses & Ion Analyses \\
\hline E144a & 4.07 & 3.55 & 3.904 & 3.455 & 0.52 & 0.449 \\
\hline E144b & 4.07 & 3.69 & 4.237 & 3.66 & 0.38 & 0.577 \\
\hline E144c & 1 & 1.9 & 2.462 & 2.276 & -0.9 & 0.186 \\
\hline E144d & 1.1 & 1.27 & 2.002 & 2.174 & -0.17 & -0.172 \\
\hline E144e & 2.05 & 2.03 & 2.219 & 1.875 & 0.02 & 0.344 \\
\hline E144f & 5.83 & 4.35 & 10.68 & 3.446 & 1.48 & 7.234 \\
\hline
\end{tabular}

\section{Appendix B: Reaction Route Group A}

ZVI redox remediation reactions, which result in the permanent removal of $\mathrm{Na}^{+}$and $\mathrm{Cl}^{-}$ions, fall into a number of distinct groups:

1. direct reaction with ZVI to produce a product;

2. catalysed reaction involving ZVI;

3. removal in hydration shells;

4. adsorption by ZVI.

\section{B.1. Direct Reaction with ZVI}

Examples of direct reaction with the ZVI to produce a precipitated product containing Fe and one or more of $\mathrm{Na}^{+}$and $\mathrm{Cl}^{-}$include:

1. $\beta-\mathrm{FeOOH}$ (akaganeite), e.g., [30-53], where the $\mathrm{Na}^{+}$and $\mathrm{Cl}^{-}$ions are concentrated in tunnels within the structure and in its hydrated ionic shell [30-53]. $\beta-\mathrm{FeOOH}$ is the dominant $\mathrm{FeOOH}$ corrosion species when the water contains significant concentrations $\mathrm{Of}^{-} \mathrm{Cl}^{-}$ions [30-53], i.e., $\log \left(\mathrm{Cl}^{-} / \mathrm{OH}^{-}\right)$is greater than 1.16 and preferably greater than eight $[2,30-53]$. The general ZVI corrosion route is [2,30-53]:

$$
\begin{gathered}
\mathrm{Fe}^{0} \rightarrow \mathrm{Fe}(\mathrm{OH})_{2} \rightarrow \mathrm{GR} 1\left(\mathrm{Cl}^{-}\right) \rightarrow \beta-\mathrm{FeOOH}(\text { akaganeite })-\text { medium Eh route [2] } \\
\mathrm{Fe}^{0} \rightarrow \mathrm{Fe}(\mathrm{OH})_{2} \rightarrow \mathrm{Fe}(\mathrm{OH})_{3} \rightarrow \beta-\mathrm{FeOOH}-\text { high Eh route [2] } \\
\mathrm{Fe}^{0} \rightarrow \mathrm{Fe}^{\mathrm{II}} \rightarrow \mathrm{Fe}^{\mathrm{II}}+\mathrm{Fe}^{\mathrm{III}} \rightarrow \mathrm{Fe}^{\mathrm{III}}[2]
\end{gathered}
$$

2. Green Rust 1 (chloride) $\left.\left(\left(\mathrm{Na}_{(a=1-c-b)}^{\mathrm{I}} \mathrm{Fe}^{\mathrm{II}}{ }_{(b=1-c-a)} \mathrm{Fe}^{\mathrm{III}}{ }_{c}(\mathrm{OH})_{\mathrm{g}}\right]^{x-} \cdot\left[(x / n) \mathrm{Cl}^{n-} \cdot m \mathrm{H}_{2} \mathrm{O}\right]^{x+}\right)\right)[2]$ $\left(\mathrm{GR} 1\left(\mathrm{Cl}^{-}\right)\right)$, ferrous hydroxychloride, e.g., [54-61]. The $\mathrm{Na}^{+}$and $\mathrm{Cl}^{-}$ions are concentrated within the layered molecular structure [54-61]. The general ZVI corrosion route is [2,54-61]:

$$
\begin{gathered}
\mathrm{Fe}^{0} \rightarrow \mathrm{Fe}(\mathrm{OH})_{2} \rightarrow \mathrm{GR} 1\left(\mathrm{Cl}^{-}\right)-\text {low Eh route [2] } \\
\mathrm{Fe}^{0} \rightarrow \mathrm{Fe}(\mathrm{OH})_{2} \rightarrow \mathrm{GR} 1\left(\mathrm{HCO}_{3}^{-}\right) \rightarrow \mathrm{GR} 1\left(\mathrm{Cl}^{-}\right)-\text {low Eh route coupled with decreasing pH [2] } \\
\mathrm{Fe}^{0} \rightarrow \mathrm{Fe}(\mathrm{OH})_{2} \rightarrow \mathrm{GR} 1\left(\mathrm{HCO}_{3}^{-}\right) \rightarrow \mathrm{GR}_{1}\left(\mathrm{Cl}^{-}\right) \rightarrow \mathrm{GR} 1\left(\mathrm{SO}_{3}^{-}\right) \rightarrow \mathrm{GR} 2\left(\mathrm{SO}_{4}^{-}\right)[2] \\
\mathrm{Fe}^{0} \rightarrow \mathrm{Fe}^{\mathrm{II}} \rightarrow \mathrm{Fe}^{\mathrm{II}}+\mathrm{Fe}^{\mathrm{III}}[2]
\end{gathered}
$$

GR1 and GR2 are different layered structural arrangements for ferrous hydroxyl species [54-61]. The structural arrangement of the layered double hydroxide (LDH) varies with the dominant anion species and the relative proportion of the different anion species (e.g., $\mathrm{OH}^{-}, \mathrm{HO}_{2}{ }^{-}, \mathrm{NO}_{3}{ }^{-}, \mathrm{HCO}_{3}{ }^{-}$, $\mathrm{CO}_{3}{ }^{2-}, \mathrm{Cl}^{-}, \mathrm{F}^{-}, \mathrm{SO}_{3}{ }^{-}, \mathrm{SO}_{4}{ }^{2-}$, etc.) contained within the structure [54-61]. 
3. Formation of sodium ferrates $\left(\mathrm{Fe}^{\mathrm{IV}}\right.$ species, $\left.\mathrm{Na}_{2} \mathrm{FeO}_{4}\right)$, e.g., [62,63]:

$$
\begin{gathered}
\mathrm{Fe}^{0} \rightarrow \mathrm{Fe}^{\mathrm{II}} \rightarrow \mathrm{Fe}^{\mathrm{II}}+\mathrm{Fe}^{\mathrm{III}} \rightarrow \mathrm{Fe}^{\mathrm{III}} \rightarrow \mathrm{Fe}^{\mathrm{IV}}[2] \\
2 \mathrm{Na}^{+}+\mathrm{FeO}_{4}^{2-}=\mathrm{Na}_{2} \mathrm{FeO}_{4} \text { (purple colour) } \\
\mathrm{HFeO}_{2}^{-}+2 \mathrm{H}_{2} \mathrm{O}=\mathrm{FeO}_{4}^{2-}+5 \mathrm{H}^{+}+4 \mathrm{e}^{-} \\
\mathrm{Fe}^{3+}+4 \mathrm{H}_{2} \mathrm{O}=\mathrm{FeO}_{4}^{2-}+8 \mathrm{H}^{+}+3 \mathrm{e}^{-} \\
\mathrm{FeOH}^{2+}+3 \mathrm{H}_{2} \mathrm{O}=\mathrm{FeO}_{4}^{2-}+7 \mathrm{H}^{+}+3 \mathrm{e}^{-}
\end{gathered}
$$

The Eh and $\mathrm{pH}$ of the product water associated with gas-pressured ZVI desalination $[1,2]$ are consistent with the removal of $\mathrm{NaCl}$ in association with $\beta-\mathrm{FeOOH}$ and ferrous hydroxychloride $[1,2]$.

\section{B.2. Direct Catalytic Reaction with ZVI}

$\mathrm{Cl}^{-}$ions act as a catalyst and phase distributor for iron corrosion (rust formation) [63-69]. The redox (Eh, $\mathrm{pH}$ ) relationships for $\mathrm{Cl}, \mathrm{Fe}$ and $\mathrm{Na}$ species (ions and precipitants) are provided in [63]. Two roles have been proposed for $\mathrm{Cl}^{-}$during iron corrosion, they are:

1. A role as a catalyser [65]:

$$
\begin{gathered}
\mathrm{Fe}^{0}+\mathrm{nCl}^{-}=\mathrm{Fe}^{\mathrm{n}+} \mathrm{nCl}^{-}+\mathrm{ne}^{-}(\text {production of intermediate }) \\
\mathrm{Fe}^{\mathrm{n}+} \mathrm{nCl}^{-}=\mathrm{Fe}^{\mathrm{n}+}+\mathrm{nCl}^{-}(\text {ionisation of } \mathrm{Fe}) \\
\mathrm{Fe}^{0} \rightarrow \mathrm{Fe}^{\mathrm{II}} \rightarrow \mathrm{Fe}^{\mathrm{II}}+\mathrm{Fe}^{\mathrm{III}} \rightarrow \mathrm{Fe}^{\mathrm{III}} \rightarrow \mathrm{Fe}^{\mathrm{IV}}
\end{gathered}
$$

The catalyser role releases electrons $\left(\mathrm{e}^{-}\right)$and $\mathrm{Fe}^{\mathrm{n}+}$ ions into the environment $[65,70]$. The released electrons catalyse a variety of remediation reactions within the water $[70,71]$.

2. A role as phase distributor [65]: The end corrosion product (rust) at the water ZVI interface is $\mathrm{FeOOH}$ (Equation (B1)). The formation of the surface rust $(\mathrm{FeOOH})$ species results in the initial corrosion $(-\mathrm{OH})$ terminal groups at the rust-water interface changing to $\left(-\mathrm{OH}_{2}\right)^{+}$groups [65]. This change both attracts $\mathrm{Cl}^{-}$ions and allows $\mathrm{Cl}^{-}$ions to migrate through the rust to the metal surface [65] (e.g., Appendix E).

\section{B.3. Removal in Hydration Shells}

The significance and structure of the hydration shells associated with the formation of Fe corrosion species is poorly understood. Two types of terminal surface occur [2,72-76]. They are:

1. Negatively-charged terminal surface: which can be defined as $\mathrm{FeOH}^{0.5-}$ and takes the general structure: $(\mathrm{OH})-(\mathrm{OH})-\mathrm{Fe}-\mathrm{O}-\mathrm{O}-\mathrm{Fe}-\mathrm{R}$ (where $\mathrm{R}=$ a repeat of the stoichiometric atomic layer sequence or tethering surface. $\mathrm{R}$ can include hydrated layers) [2]. A double hydrated terminal surface takes the form: $\left(\mathrm{H}_{2} \mathrm{O}\right)-\left(\mathrm{H}_{2} \mathrm{O}\right)-(\mathrm{OH})-(\mathrm{OH})-\mathrm{Fe}-\mathrm{O}-\mathrm{O}-\mathrm{Fe}-\mathrm{R}$ [2]. This surface type has a negative charge and can be expected to remove $\mathrm{Na}^{+}$ions from the water [2].

2. Positively-charged interface terminal surface: which can be defined as $\mathrm{FeOH}_{2}{ }^{0.5+}$ and takes the general structure: $\left(\mathrm{OH}_{2}\right)-(\mathrm{OH})-\mathrm{Fe}-\mathrm{O}-\mathrm{O}-\mathrm{Fe}-\mathrm{R}$ [2]. A double hydrated interface terminal surface takes the form: $\left(\mathrm{H}_{2} \mathrm{O}\right)-\left(\mathrm{H}_{2} \mathrm{O}\right)-\left(\mathrm{OH}_{2}\right)-(\mathrm{OH})-\mathrm{Fe}-\mathrm{O}-\mathrm{O}-\mathrm{Fe}-\mathrm{R}$ [2]. This surface type has a positive charge and can be expected to remove $\mathrm{Cl}^{-}$ions from the water [2]. 


\section{B.4. Adsorption}

The ZVI corrosion surface is covered with surface hydroxyl groups ( $\equiv \mathrm{Fe}-\mathrm{OH})$. These groups are ampholytes and are able to react to produce positively- and negatively-charged surfaces [77]:

$$
\begin{gathered}
\equiv \mathrm{Fe}-\mathrm{OH}+\mathrm{H}^{+}=\equiv \mathrm{Fe}-\mathrm{OH}_{2}^{+} \\
\equiv \mathrm{Fe}-\mathrm{OH}=\equiv \mathrm{Fe}-\mathrm{O}^{-}+\mathrm{H}^{+}
\end{gathered}
$$

Cation $\left(\mathrm{Me}^{+}\right)$and anion (ligand, L) adsorption is explained by Lewis base relationships [77]. Cation adsorption (e.g., $\mathrm{Na}^{+}$) is characterised by the release of hydrogen ions, while anion adsorption is characterised by the release of hydroxyl groups [77]:

$$
\begin{gathered}
\equiv \mathrm{Fe}-\mathrm{OH}+\mathrm{Me}^{\mathrm{n}+}\left(\text { e.g., } \mathrm{Na}^{+}\right)=\equiv \mathrm{Fe}-\mathrm{OMe}^{\mathrm{n}+}\left(\text { e.g., } \equiv \mathrm{Fe}-\mathrm{ONa}^{+}\right)+\mathrm{H}^{+} \\
\equiv \mathrm{Fe}-\mathrm{OH}+\mathrm{L}^{-}\left(\text {e.g., } \mathrm{Cl}^{-}\right)=\equiv \mathrm{Fe}-\mathrm{L}(\text { e.g., } \mathrm{Fe}-\mathrm{Cl})+\mathrm{OH}^{-}
\end{gathered}
$$

The initial theories for the mechanism of ZVI desalination are by: (i) ion exchange in double layered hydroxides [26]; and (ii) by direct adsorption onto corroding ZVI surfaces [1-5]. Both theories assume that the $\mathrm{Na}^{+}$and $\mathrm{Cl}^{-}$ions are permanently removed from the water and are retained with the ZVI bed and any Fe corrosion product precipitates, which are entrained in the product water.

\section{Appendix C: Reaction Route Group B}

Redox reactions include reactions where the dominant ion adduct, or ions, are controlled by the Eh and $\mathrm{pH}$ of the water $[63,70,71]$. Both reactants and products associated with this type of reaction are soluble in water $[63,70,71]$. This type of ion remediation is a characteristic of ZVI redox remediation for organo-halides, nitrates, oxides, hydroxides and sulphur species [26,63,70,71]. Typical ZVI nitrate removal reactions include $[63,71]$ :

$$
\begin{gathered}
\mathrm{NO}_{3}^{-}+\mathrm{H}_{3} \mathrm{O}^{+}\left[\mathrm{H}_{2} \mathrm{O}\right]_{2}=\mathrm{NH}_{4}^{+}+3 \mathrm{HO}_{2}^{-} \\
\mathrm{NO}_{3}^{-}+\mathrm{H}_{3} \mathrm{O}^{+}\left[\mathrm{H}_{2} \mathrm{O}_{2}=\mathrm{NH}_{4}^{+}+3 \mathrm{HO}^{-}+1.5 \mathrm{O}_{2}(\mathrm{~g}, \mathrm{aq})\right. \\
2 \mathrm{NO}_{3}^{-}+12 \mathrm{H}^{+}+10 \mathrm{e}^{-}=\mathrm{N}_{2}(\mathrm{~g}, \mathrm{aq})+6 \mathrm{H}_{2} \mathrm{O} \\
\mathrm{NO}_{3}^{-}+2 \mathrm{H}^{+}=\mathrm{NO}_{2}^{-}+\mathrm{H}_{2} \mathrm{O}
\end{gathered}
$$

ZVI-induced organo-chloride removal reactions fall into three free electron catalysed groups [71]. The appropriate reactions for organo-halides or organo-halides formed on catalytic sites within the ZVI include ZVI surface-based reactions [71].

\section{C.1. n-Fe Surface-Based Reaction or Aqueous ZVM Ion-Based Reaction [71]}

$$
\begin{aligned}
& \text { Initial ZVI nano - scale reaction }-\mathrm{xC}^{\mathrm{s}(+/-)}+\mathrm{zH}^{+}+\mathrm{yCl}^{-}=\mathrm{H}_{\mathrm{z}} \mathrm{C}_{\mathrm{x}} \mathrm{Cl}_{\mathrm{y}} \text { (corrosion product) } \\
& \mathrm{H}_{\mathrm{z}} \mathrm{C}_{\mathrm{x}} \mathrm{Cl}_{\mathrm{y}} \text { (corrosion product or pollutant) }+\mathrm{e}^{-}=\mathrm{H}_{\mathrm{z}} \mathrm{C}_{\mathrm{x}} \mathrm{Cl}_{\mathrm{y}}^{-} \\
& \mathrm{H}_{\mathrm{z}} \mathrm{C}_{\mathrm{x}} \mathrm{Cl}_{\mathrm{y}}^{-}+\mathrm{Fe}^{\mathrm{n}+}=\left[\mathrm{H}_{\mathrm{z}} \mathrm{C}_{\mathrm{x}} \mathrm{Cl}_{\mathrm{y}}-\mathrm{Fe}^{(\mathrm{n}-1)+}\right. \\
& {\left[\mathrm{H}_{\mathrm{z}} \mathrm{C}_{\mathrm{x}} \mathrm{Cl}_{\mathrm{y}}-\mathrm{Fe}\right]^{(\mathrm{n}-1)+}+\mathrm{H}_{2} \mathrm{O}=\left[\mathrm{H}_{\mathrm{z}+1} \mathrm{C}_{\mathrm{x}} \mathrm{Cl}_{\mathrm{y}-1}\right]+\mathrm{Fe}-\mathrm{Cl}^{(\mathrm{n}-1)+} \text { (ion adduct) } \mathrm{OH}+\mathrm{e}^{-}} \\
& \mathrm{x} \mathrm{C}^{\mathrm{s}(+/-)} \text { sites form in the corroding iron when the iron contains carbon }[2]
\end{aligned}
$$

C.2. n-Fe-Hydroxide/Peroxide Surface-Based Reaction or Aqueous Fe-Hydroxide/Peroxide Ion-Based Reaction [71]

$$
\begin{aligned}
& \text { Initial ZVI nano - scale reaction }-\mathrm{xC}^{\mathrm{s}(+/-)}+\mathrm{zH}^{+}+\mathrm{yCl}^{-}=\mathrm{H}_{\mathrm{z}} \mathrm{C}_{\mathrm{x}} \mathrm{Cl}_{\mathrm{y}} \text { (corrosion product) } \\
& \mathrm{Fe}_{\mathrm{j}} \mathrm{O}_{\mathrm{k}} \mathrm{H}_{\mathrm{d}}^{\mathrm{n}+}+\mathrm{H}_{\mathrm{z}} \mathrm{C}_{\mathrm{x}} \mathrm{Cl}_{\mathrm{y}} \text { (corrosion product or pollutant) }+\mathrm{e}^{-}=\left[\mathrm{H}_{\mathrm{z}} \mathrm{C}_{\mathrm{x}} \mathrm{Cl}_{\mathrm{y}}-\mathrm{Fe}_{\mathrm{j}} \mathrm{O}_{\mathrm{k}} \mathrm{H}_{\mathrm{d}}\right]^{(\mathrm{n}-1)+} \\
& {\left[\mathrm{H}_{\mathrm{z}} \mathrm{C}_{\mathrm{x}} \mathrm{Cl}_{\mathrm{y}}-\mathrm{Fe}_{\mathrm{j}} \mathrm{O}_{\mathrm{k}} \mathrm{H}_{\mathrm{d}}\right]^{(\mathrm{n}-1)+}+\mathrm{H}_{2} \mathrm{O}=\left[\mathrm{H}_{\mathrm{z}+1} \mathrm{C}_{\mathrm{x}} \mathrm{Cl}_{\mathrm{y}-1}\right]+\mathrm{Fe}_{\mathrm{j}} \mathrm{O}_{\mathrm{k}+1} \mathrm{H}_{\mathrm{d}+1}^{(\mathrm{n}-2)+}+\mathrm{Cl}+\mathrm{e}^{-}}
\end{aligned}
$$


C.3. n-Fe Surface-Based Reaction or Aqueous ZVM Ion-Based Reaction [71]

$$
\begin{gathered}
\mathrm{H}_{\mathrm{z}} \mathrm{C}_{\mathrm{x}} \mathrm{N}_{3} \mathrm{Cl}_{\mathrm{y}}+\mathrm{e}^{-}=\mathrm{H}_{\mathrm{z}} \mathrm{C}_{\mathrm{x}} \mathrm{N}_{3} \mathrm{Cl}_{\mathrm{y}}^{-} \\
\mathrm{H}_{\mathrm{z}} \mathrm{C}_{\mathrm{x}} \mathrm{N}_{3} \mathrm{Cl}_{\mathrm{y}}^{-}+\mathrm{Fe}^{\mathrm{n}+}=\left[\mathrm{H}_{\mathrm{z}} \mathrm{C}_{\mathrm{x}} \mathrm{N}_{3} \mathrm{Cl}_{\mathrm{y}}-\mathrm{Fe}\right]^{(\mathrm{n}-1)+} \\
{\left[\mathrm{H}_{\mathrm{z}} \mathrm{C}_{\mathrm{x}} \mathrm{N}_{3} \mathrm{Cl}_{\mathrm{y}}-\mathrm{Fe}\right]^{(\mathrm{n}-1)+}+\mathrm{H}_{2} \mathrm{O}=\left[\mathrm{H}_{\mathrm{z}+1} \mathrm{C}_{\mathrm{x}} \mathrm{N}_{3} \mathrm{Cl}_{\mathrm{y}-1}\right]+\mathrm{FeCl}^{(\mathrm{n}-1)+}+\mathrm{OH}+\mathrm{e}^{-}}
\end{gathered}
$$

\section{C.4. Implications of Surface-Based Reactions}

These reaction series (Equations (C2)-(C4)) demonstrate that $\mathrm{e}^{-}$may act as a catalyst $[70,71]$. They create the possibility that in a gas-pressured reactor, the initial stages in the removal of $\mathrm{NaCl}$ may involve radicals associated with the pressurizing gases, $\mathrm{O}_{2}$ and $\mathrm{CO}_{2}$. This would allow:

1. the $\mathrm{Na}^{+}$and $\mathrm{Cl}^{-}$ion concentrations measured in the product water within the reactor to decline as the concentration of radical products increased;

2. the desalination reactions to be reversed in the stored water, as the $\mathrm{pH}$ changes;

3. the relative molar proportion of $\mathrm{Na}: \mathrm{Cl}$ ions in the product water to be adjusted during reactor operation.

\section{C.5. Pressurization by $\mathrm{CO}_{2}$}

When the water is pressured by $\mathrm{CO}_{2}$, the generic $\mathrm{pH}$ sensitive reaction sequence is [63]:

$$
\mathrm{H}_{2} \mathrm{O}+\mathrm{CO}_{2}=\mathrm{H}_{2} \mathrm{CO}_{3}=\mathrm{HCO}_{3}^{-}+\mathrm{H}^{+}=\mathrm{CO}_{3}^{2-}+2 \mathrm{H}^{+}
$$

This reaction is characterized by an initial $\mathrm{pH}$ drop as $\mathrm{H}_{2} \mathrm{CO}_{3}$ is formed [63] (e.g., CSD, E143, E144 trial series). When $\mathrm{CO}_{2}$ gas charging ceases, the $\mathrm{pH}$ gradually rises as the proportion of, first, $\mathrm{HCO}_{3}{ }^{-}$ and, then, $\mathrm{CO}_{3}{ }^{2-}$ increases $[2,63]$.

\section{C.6. Pressurization by $\mathrm{O}_{2}$}

When the water is pressured by $\mathrm{O}_{2}$ (air), the generic $\mathrm{pH}$ sensitive reaction sequence is [63]:

$$
\mathrm{H}_{2} \mathrm{O}+0.5 \mathrm{O}_{2}+2 \mathrm{e}^{-}=2 \mathrm{OH}^{-}
$$

This reaction is characterized by an initial increase in $\mathrm{pH}$ to a stable level $[2,63]$ (e.g., E146 trial series). Cessation of $\mathrm{O}_{2}$ gas charging may partially reverse the reaction and may be associated with a $\mathrm{pH}$ reduction and/or Eh change [2,63,70].

C.7. Generic ZVI Reactions Associated with $\mathrm{CO}_{2}$ and $\mathrm{O}_{2}$ Gas Charging

During $\mathrm{CO}_{2}$ charging $[2,63,70,71]$ :

$$
\begin{gathered}
\mathrm{Fe}(\mathrm{s})+2 \mathrm{H}^{+}(\mathrm{aq})=\mathrm{Fe}^{2+}(\mathrm{aq})+\mathrm{H}_{2}(\mathrm{~g}, \mathrm{aq}) \\
\mathrm{H}_{2}(\mathrm{~g}, \mathrm{aq})=2 \mathrm{H}^{+}+2 \mathrm{e}^{-} \\
\mathrm{Fe}(\mathrm{s})+2 \mathrm{H}^{+}(\mathrm{aq})=\mathrm{Fe}^{2+}(\mathrm{aq})+\mathrm{aH}_{2}(\mathrm{~g}, \mathrm{aq})+\mathrm{b}\left(2 \mathrm{H}^{+}\right)+\mathrm{b}\left(2 \mathrm{e}^{-}\right)
\end{gathered}
$$

During $\mathrm{O}_{2}$ charging $[2,63,70,71]$ :

$$
\begin{gathered}
\mathrm{Fe}^{2+}(\mathrm{aq})+2 \mathrm{OH}^{-}(\mathrm{aq})=\mathrm{Fe}(\mathrm{OH})_{2}(\mathrm{~s}) \\
\mathrm{Fe}(\mathrm{OH})_{2}+0.5 \mathrm{O}_{2}+\mathrm{e}^{-}=\mathrm{FeOOH}+\mathrm{OH}^{-} \\
\mathrm{Fe}^{2+}(\mathrm{aq})+2 \mathrm{OH}^{-}(\mathrm{aq})+0.5 \mathrm{O}_{2}+\mathrm{e}^{-}=\mathrm{FeOOH}+\mathrm{OH}^{-}
\end{gathered}
$$




\section{C.8. Na Removal Associated with Fe Valency Changes}

If a generic anodic Fe oxyhydroxide ion site takes the form $\left[\left(\mathrm{Fe}_{2}(\mathrm{OH})_{6}\left(\mathrm{OH}_{2}\right)_{3}\right]^{2-}\right.$, then the corresponding generic cathodic site may take the form $\left[\mathrm{Fe}_{2} \mathrm{O}_{3}(\mathrm{OH})_{3}\left(\mathrm{OH}_{2}\right)_{3}\right]^{3-}[78-80]$. This allows the $\mathrm{Na}^{+}$removal (adsorption) reaction to occur when the Fe valency increases from 2 to 3:

$$
\left[\left(\mathrm{Fe}^{\mathrm{II}}\right)_{2}(\mathrm{OH})_{6}\left(\mathrm{OH}_{2}\right)_{3}\right]^{2-}+3 \mathrm{Na}^{+}+3 \mathrm{OH}^{-}=\left[\left(\mathrm{Fe}^{\mathrm{III}}\right)_{2} \mathrm{O}_{3}(\mathrm{OH})_{3}\left(\mathrm{OH}_{2}\right)_{3}\right]^{3-} \cdot 3 \mathrm{Na}^{+}+3 \mathrm{H}_{2} \mathrm{O}+2 \mathrm{e}^{-}
$$

In this example, the generic Fe oxyhydroxide ion pair takes the form $\left[\left(\mathrm{Fe}_{\mathrm{m}}(\mathrm{OH})_{\mathrm{x}}\left(\mathrm{OH}_{2}\right)_{\mathrm{y}}\right]^{n-}\right.$ and $\left[\mathrm{Fe}_{\mathrm{m}} \mathrm{O}_{\mathrm{p}}(\mathrm{OH})_{\mathrm{a}}\left(\mathrm{OH}_{2}\right)_{b}\right]^{k-}[78-80]$. The control on the amount of $\mathrm{Na}^{+}$that can be adsorbed is a function of the availability of $\mathrm{OH}^{-}$ions (i.e., an increase in $\mathrm{pH}$ ). An increase in $\mathrm{Na}^{+}$adsorption will result in an increase in the availability of $\mathrm{e}^{-}$. Equation (C9) implies that if: (i) the $\mathrm{pH}$ of water is raised by $\mathrm{O}_{2}$ charging (producing $\mathrm{OH}^{-}$ions); and (ii) the gas charging is then removed; then (iii) the $\mathrm{pH}$ (and $\mathrm{Na}^{+}$ ion concentration) will decline during the subsequent time period e.g., CSD1 and E143 trial series [2]. The generic reaction takes the simplified form [78-80]:

$$
\begin{gathered}
{\left[(\mathrm{OH})_{6}\left(\mathrm{OH}_{2}\right)_{3}\right]^{6-}+6 \mathrm{Na}^{+}=\left[(\mathrm{OH})_{6}\left(\mathrm{OH}_{2}\right)_{3}\right]^{6-} \cdot 6 \mathrm{Na}^{+}} \\
\left(\equiv\left[(\mathrm{OH})_{6}\left(\mathrm{OH}_{2}\right)_{3}\right]^{(6-\mathrm{n})-}\right)+(6-\mathrm{n}) \mathrm{Na}^{+}=\left(\equiv\left[(\mathrm{OH})_{6}\left(\mathrm{OH}_{2}\right)_{3}\right]^{(6-\mathrm{n})-} \cdot(6-\mathrm{n}) \mathrm{Na}^{+}\right) \\
(\equiv)=\text { site with a charge of } \mathrm{n}(+), \text { e.g., } \equiv\left(\mathrm{OH}_{2}\right)^{+} \\
\left(\equiv\left[(\mathrm{OH})_{6}\left(\mathrm{OH}_{2}\right)_{3}\right]^{(6-\mathrm{n})-}\right) \text { can be }\left(\equiv\left[(\mathrm{OH})_{\mathrm{m}}\left(\mathrm{OH}_{2}\right)_{\mathrm{y}}\right] \cdot \mathrm{z}\left(\mathrm{OH}_{2}\right)^{+}\right)(\mathrm{m}-\mathrm{n}-\mathrm{z})- \\
\text { In the presence of } \mathrm{CO}_{2} \text { the adsorption site may potentially take the form : } \\
\left(\equiv\left[(\mathrm{OH})_{\mathrm{m}}\left(\mathrm{CO}_{2}\right)_{\mathrm{d}}\left(\mathrm{HCO}_{3}\right)_{\mathrm{e}}\left(\mathrm{CO}_{3}\right)_{\mathrm{f}}\left(\mathrm{OH}_{2}\right)_{\mathrm{y}}\right] \mathrm{z}\left(\mathrm{OH}_{2}\right)^{+}\right)(\mathrm{m}+\mathrm{e}+2 \mathrm{f}-\mathrm{n}-\mathrm{z})-
\end{gathered}
$$

The hydrated hydroxide ion may be replaced or supplemented with an alternative hydrated anion (e.g., $\mathrm{HCO}_{3}{ }^{-}, \mathrm{CO}_{3}{ }^{2-}$, etc.). In these examples, the $\mathrm{Na}^{+}$ion concentration will show a decrease using an ion analyser, but the total amount of $\mathrm{Na}$ in the water will remain constant (unless the hydrated hydroxide ion adduct is attached to a precipitated particle, which can be removed by filtration prior to analysis). The reduction in $\mathrm{Na}^{+}$ion concentration will signify a decrease in salinity.

\section{C.9. Catalysed Cl Removal Associated with Fe}

The catalysed $\mathrm{Cl}^{-}$removal reaction may take the form $[71,81]$ :

$$
\begin{gathered}
0.5 \mathrm{Cl}_{2}+\mathrm{e}^{-}+\left[\mathrm{Fe}_{\mathrm{j}} \mathrm{O}_{\mathrm{k}}+{ }_{1} \mathrm{H}_{\mathrm{d}}+1\right]^{(\mathrm{n}-2)+}+\left[\mathrm{H}_{\mathrm{z}}+{ }_{1} \mathrm{C}_{\mathrm{x}} \mathrm{Cl}_{\mathrm{y}-1}\right]=\mathrm{H}_{2} \mathrm{O}+\left[\mathrm{H}_{\mathrm{z}} \mathrm{C}_{\mathrm{x}} \mathrm{Cl}_{\mathrm{y}}-\mathrm{Fe}_{\mathrm{j}} \mathrm{O}_{\mathrm{k}} \mathrm{H}_{\mathrm{d}}\right]^{(\mathrm{n}-1)+} \\
\left.H_{\mathrm{z}} \mathrm{C}_{\mathrm{x}} \mathrm{Cl} l_{\mathrm{y}}-\mathrm{Fe}_{\mathrm{j}} \mathrm{O}_{\mathrm{k}} H_{\mathrm{d}}\right]^{(n-1)+}=\mathrm{H}_{\mathrm{z}} \mathrm{C}_{\mathrm{x}} \mathrm{Cl}_{\mathrm{y}}+\left[\mathrm{Fe}_{\mathrm{j}} \mathrm{O}_{\mathrm{k}} H_{\mathrm{d}}\right]^{\mathrm{n}+}+e^{-}
\end{gathered}
$$

The catalysed reaction route is complicated further in the presence of bicarbonate species as $[65,70,71,81-83]$ :

$$
\begin{gathered}
0.5 \mathrm{Cl}_{2}+\mathrm{e}^{-}+\left[\mathrm{Fe}_{\mathrm{j}} \mathrm{O}_{\mathrm{k}}+{ }_{1} \mathrm{H}_{\mathrm{d}+1}\right]^{(\mathrm{n}-2)+}+\left[\mathrm{H}_{\mathrm{z}}+{ }_{1} \mathrm{C}_{\mathrm{x}} \mathrm{O}_{\mathrm{n}} \mathrm{Cl}_{\mathrm{y}-1}\right]=\mathrm{H}_{2} \mathrm{O}+\left[\mathrm{H}_{\mathrm{z}} \mathrm{C}_{\mathrm{x}} \mathrm{O}_{\mathrm{n}} \mathrm{Cl}_{\mathrm{y}}-\mathrm{Fe}_{\mathrm{j}} \mathrm{O}_{\mathrm{k}} \mathrm{H}_{\mathrm{d}}\right]^{(\mathrm{n}-1)+} \\
\left.\mathrm{H}_{\mathrm{z}} \mathrm{C}_{\mathrm{x}} \mathrm{O}_{\mathrm{n}} \mathrm{Cl}_{\mathrm{y}}-\mathrm{Fe}_{\mathrm{j}} \mathrm{O}_{\mathrm{k}} \mathrm{H}_{\mathrm{d}}\right]^{(\mathrm{n}-1)+}=\mathrm{H}_{\mathrm{z}} \mathrm{C}_{\mathrm{x}} \mathrm{O}_{\mathrm{n}} \mathrm{Cl}_{\mathrm{y}}+\left[\mathrm{Fe}_{\mathrm{j}} \mathrm{O}_{\mathrm{k}} \mathrm{H}_{\mathrm{d}}\right]^{\mathrm{n}+}+\mathrm{e}^{-}
\end{gathered}
$$

Bicarbonate/carbonate ions and chloride actively facilitate and encourage $\mathrm{Fe}^{0}$ to act as a catalyst in the aqueous environment in the presence of $\mathrm{CO}_{x}$ gas species $[81,82]$.

\section{C.10. UV Absorption Peaks which May Be Associated with Catalysed Cl Removal}

The generic reactions (Equations (C9)-(C12)) imply that UV-visible absorbance spectra of nano-particles forming within a gas charged reactor should show evidence of $\mathrm{H}_{\mathrm{z}} \mathrm{C}_{\mathrm{x}} \mathrm{O}_{\mathrm{n}} \mathrm{Cl}_{\mathrm{y}}$ species $(230-250 \mathrm{~nm})$ [83-85], $\mathrm{HCO}_{3}{ }^{-}$species $(275 \mathrm{~nm})[2]$ and $\left(\equiv\left[(\mathrm{OH})_{6}\left(\mathrm{OH}_{2}\right)_{3}\right]^{(6-n)-} \cdot \mathrm{a}(6-\right.$ n) $\left.\mathrm{Na}^{+}\right)^{(-(6-n)+a(6-n))}$ species $(262 / 8 \mathrm{~nm}, 275 / 6 \mathrm{~nm}, 301 \mathrm{~nm}, 324 / 8 \mathrm{~nm}, 337 \mathrm{~nm}, 351 \mathrm{~nm}, 365 \mathrm{~nm}$, $395 \mathrm{~nm})$ [2]. 


\section{C.10.1. UV-Visible Absorbance Peaks Associated with Cl Species}

The specific adsorption (peak) wavelengths of potential $\mathrm{Cl}^{-}$products include: $\mathrm{Cl}_{2}=250 \mathrm{~nm}$, $330 \mathrm{~nm}[83,84] ; \mathrm{ClO}=270 \mathrm{~nm}[83] ; \mathrm{ClO}^{-}=290 \mathrm{~nm}$ [2]; $\mathrm{Cl}_{2} \mathrm{O}=250-260 \mathrm{~nm}$ [83]; $\mathrm{ClO}_{2}=292 \mathrm{~nm}$ [2]; $\mathrm{ClClO}_{2}=230 \mathrm{~nm}$ [83]; $\mathrm{Cl}_{2} \mathrm{O}_{4}=230-235 \mathrm{~nm}$ [83]; $\mathrm{Cl}_{2} \mathrm{O}_{6}=215 \mathrm{~nm}$ [83]; OClO = 340-360 nm [83];

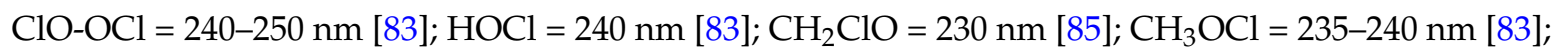
$\mathrm{COHCl}=245-260 \mathrm{~nm}$ [83]; $\mathrm{CH}_{2} \mathrm{ClCHO}=290-310 \mathrm{~nm}$ [83]; $\mathrm{CHCl}_{2} \mathrm{CHO}=295-300 \mathrm{~nm}$ [83]; $\mathrm{CCl}_{3} \mathrm{CHO}=290-295 \mathrm{~nm}$ [83]; $\mathrm{CH}_{3} \mathrm{C}(\mathrm{O}) \mathrm{Cl}=235-245 \mathrm{~nm}$ [83]; $\mathrm{CH}_{2} \mathrm{ClCOCl}=240-250 \mathrm{~nm}$ [83]; $\mathrm{CHCl}_{2} \mathrm{C}(\mathrm{O}) \mathrm{Cl}=250-260 \mathrm{~nm}$ [83]; $\mathrm{CCl}_{3} \mathrm{C}(\mathrm{O}) \mathrm{Cl}=245-265 \mathrm{~nm}$ [83]; $\mathrm{CH}_{3} \mathrm{C}(\mathrm{O}) \mathrm{CH}_{2} \mathrm{Cl}=220-235 \mathrm{~nm}$ [83]. This list is not definitive, and other $\mathrm{H}_{\mathrm{z}} \mathrm{C}_{\mathrm{x}} \mathrm{O}_{\mathrm{n}} \mathrm{Cl}_{\mathrm{y}}$ species exist.

C.10.2. UV-Visible Absorbance Peaks Associated with Nano-Particles Produced during Desalinations

The published UV-visible absorbance spectra for nano-particles produced by an active gas-charged ZVI desalination reactor have been interpreted [2] as being a result of the formation of Fe ion species, $\mathrm{O}_{\mathrm{x}} \mathrm{H}_{\mathrm{y}}$ radicals, $\mathrm{O}_{2}{ }^{-}, \mathrm{NaO}^{-}, \mathrm{ClO}-\mathrm{OCl}, \mathrm{ClO}_{2}$ and $\mathrm{ClO}^{-}$.

\section{Appendix D: Significance of Higher Residual Salinities in the Manifold and ZVI Cartridge}

Higher residual salinity levels (based on EC) have been recorded in the manifold $\left(50.17 \mathrm{mS} \cdot \mathrm{cm}^{-1}\right)$ and ZVI cartridge ( $\left.350.37 \mathrm{mS} \cdot \mathrm{cm}^{-1}\right)$ associated with the E143 trial series [2]. The ion analyses in Table A6 confirm these elevated salinities: (i) manifold (28.62 g. $\left.\mathrm{L}^{-1}\right)$; and (ii) ZVI cartridge (446.678 g $\mathrm{Na}^{+} \cdot \mathrm{L}^{-1}+144.185 \mathrm{~g} \mathrm{Cl}^{-} \cdot \mathrm{L}^{-1}$ ). Desorption of $\mathrm{NaCl}$ from the ZVI (within the reactor) may account for the occasional increases in product water salinity observed in the E143 series trials (Tables A3-7).

Analysis of the $\mathrm{Na}: \mathrm{Cl}$ molar ratio in the water associated with the E143k trial (Figure D1) establishes that the product water is depleted of $\mathrm{Na}^{+}$ions, while the relative concentration of $\mathrm{Na}^{+}$ions progressively increases through the manifold and into the attached ZVI cartridge.



Figure D1. Comparison of molar $\mathrm{Na}: \mathrm{Cl}$ ratios from the feed water, product water; manifold water and ZVI cartridge water associated with Trial E143k. Data Source: Table A6.

\section{D.1. Salinity Concentration Associated with ZVI Corrosion Products}

Sediment located $0.1-0.4 \mathrm{~m}$ below the seawater-seabed interface has been demonstrated to concentrate $\mathrm{Cl}^{-}$ions from $18.986 \mathrm{~g} \mathrm{Cl}^{-} \cdot \mathrm{L}^{-1}$ in the seawater to $20-24 \mathrm{~g} \mathrm{Cl}^{-} \cdot \mathrm{L}^{-1}$ when akaganeite has formed as a digenetic product [86]. The observations in Figure D1 are therefore consistent with observations made in the natural environment.

Akaganeite concentrates $\mathrm{Na}^{+}$and $\mathrm{Cl}^{-}$ions in its hydrated shell [49] and concentrates $\mathrm{Cl}^{-}$ions within molecular tunnels inside its crystallites [49]. The observations in Figure D1 are consistent with ZVI corrosion products preferentially attracting $\mathrm{Na}^{+}$and $\mathrm{Cl}^{-}$ions from the water and preferentially binding the $\mathrm{Cl}^{-}$ions into pores within the ZVI corrosion products. The high $\mathrm{Na}: \mathrm{Cl}$ ratio in the ZVI 
implies that a substantial part of the $\mathrm{Na}^{+}$ions is held as $\mathrm{NaOH}, \mathrm{NaO}^{-},\left(\equiv\left[(\mathrm{OH})_{6}\left(\mathrm{OH}_{2}\right)_{3}\right]^{(6-n)-} \cdot \mathrm{a}(6-\right.$ n) $\left.\mathrm{Na}^{+}\right)^{(-(6-n)+a(6-n))}$ species in the pore waters. The $\mathrm{Na}^{+}$ions may be bound to the ZVI through sites of the type: $\equiv \mathrm{Fe}-\mathrm{ONa}^{+} ; \mathrm{FeOH}^{0.5-},((\mathrm{OH})-(\mathrm{OH})-\mathrm{Fe}-\mathrm{O}-\mathrm{O}-\mathrm{Fe}-\mathrm{R})^{n-}$; or through tethered anodic groups (electrochemical redox switchable moieties), which are attached to the ZVI or ZVI corrosion products $[1,87-89]$.

\section{D.2. Recovery of $\mathrm{NaCl}$ Held in ZVI Corrosion Products}

Mineralogical studies [40,41] and museum conservation studies [30-36] have established that both $\mathrm{Na}^{+}$and $\mathrm{Cl}^{-}$ions can be removed from the ZVI corrosion products by washing. Displacement of $\mathrm{Na}^{+}$and $\mathrm{Cl}^{-}$ions concentrated in the ZVI may occur when a batch of product water is replaced by a new batch of feed water [28-34,38,39]. This can potentially result in concentrations of $\mathrm{Na}^{+}$ions and/or $\mathrm{Cl}^{-}$ions being higher in the resulting product water than in the feed water. Examples of this situation are provided by Trials E143f and E143i (Table A5).

This situation was observed in less than $10 \%$ of the trials considered in this study and does not occur if the ZVI cartridge is fully drained (and rinsed) at the conclusion of each trial.

\section{D.3. Significance of Water Volume Reduction}

Product water associated with conventional desalination plants (e.g., reverse osmosis, etc.) is typically within the range of $20 \%-50 \%$ of the feed water [18-23]. The residual enhanced salinity waste water (reject brine) is discharged into the environment [18-23]. The discharged waste water volume is in the order of $50 \%-80 \%$ of the feed water volume [18-23].

\section{D.3.1. Observed Water Volume Reduction}

Unlike conventional desalination processes, the gas-pressured static diffusion desalination process produces no waste water [1-5]. The product water volume can decline with increasing time in the reaction environment [2]. The water volume losses recorded in Tables A1-A11 are between $10 \%$ and $40 \%$. Water volume losses occur as a result of the following chemical processes:

1. Reactions between the ZVI and water (e.g., Appendix B and Appendix C $[63,70,71]$ );

2. Reactions between the ZVI and gas (e.g., Appendix $B$ and Appendix $C[63,70,71]$ );

3. Reactions between the $\mathrm{ZVI}, \mathrm{Na}^{+}$ions and $\mathrm{Cl}^{-}$ions (e.g., Appendix $\mathrm{B}$ and Appendix $\mathrm{C}[63,70,71]$ ).

The bulk of the water losses are associated with physical processes:

1. Water losses associated with evaporation at the gas: water contact;

2. Water losses associated with humidification as a dry gas is bubbled through the water.

The principal water loss in trials CSD1, E143 and E144 results from humidification. In these trials, the waste gas was vented into the atmosphere. In commercial unit humidification (and evaporation), losses are reduced by capturing and recycling the bulk of the discharging gas.

Water losses associated with humidification have been demonstrated to be negligible when the gas is humidified prior to use (e.g., E146 trial series [2]).

A suitably-designed commercial gas-pressured static diffusion desalination reactor can be expected to operate with water losses of less than $5 \%$. This compares to water losses of $50 \%-80 \%$, which are associated with conventional desalination plants [18-23].

\section{D.3.2. Impact of High Water Losses Due to Suboptimal Reactor Design on Desalination Assessment}

An earlier study established [1] that the humidified gas does not remove $\mathrm{Na}^{+}$ions and $\mathrm{Cl}^{-}$ ions from the water body. Water volume reductions associated with humidification will increase the product water salinity, due to the concentration of the residual $\mathrm{NaCl}$ [2]. 
An increase in $\mathrm{NaCl}$ concentration in the product water in these circumstances can mask a net removal of $\mathrm{NaCl}$ [2], i.e., with the placement of $1 \mathrm{~g} \mathrm{NaCl} / \mathrm{L}$ in the reactor, with a $50 \%$ reduction in product water volume, one would expect to recover water with a salinity of $2 \mathrm{~g} \mathrm{NaCl} / \mathrm{L}$ [2]. If the product water has a salinity of less than $2 \mathrm{~g} \mathrm{NaCl} / \mathrm{L}$, then part of the excess salinity will have been removed by the ZVI [2].

No attempt was made in the design and construction of the trial reactors used in the trials (Tables A1-A11) to minimize water losses due to humidification [2]. This was a deliberate design decision for the trials. The trial design was used to establish whether a gas process (recycle) loop (Figure 2) would be required in a commercial unit to minimize humidification losses.

Trial examples, E143f-E143i (Table A4), demonstrate increased raw product water salinities. Mass balance analyses, which adjust the salinities for water consumption (e.g., Table A5) are required to establish if the increased salinity results from:

1. no desalination occurring [2];

2. a real increase in salinity due to displacement of previously-removed $\mathrm{NaCl}$ from the $\mathrm{ZVI}$ into the product water;

3. desalination occurring at a slower rate than the rate of water removal [2].

The mass balance analysis (Table A5) establishes that (with the exception of Trials E143f and E143i) there has been a net removal of $\mathrm{Na}^{+}$ions and $\mathrm{Cl}^{-}$ions in these trials.

\section{D.4. Different $\mathrm{Na}^{+}$and $\mathrm{Cl}^{-}$Ion Concentrations in Different Parts of the Reactor}

The ion concentrations for Trial E143k (Figure D2, Table A6) demonstrate that the $\mathrm{Cl}^{-}$ion concentration in the raw product water is greater than the $\mathrm{Cl}^{-}$ion concentration in the feed water. The $\mathrm{Na}^{+}$ion concentration (and total salinity) is lower in the product water (Figure D2, Table A6). The mass balance analysis establishes (Table A5) that both $\mathrm{Na}^{+}$and $\mathrm{Cl}^{-}$ions have been removed from the product water. In this example (Trial E143k), the rate of $\mathrm{Cl}^{-}$removal is less than the rate of water removal, while the rate of $\mathrm{Na}^{+}$removal is greater than the rate of water removal.
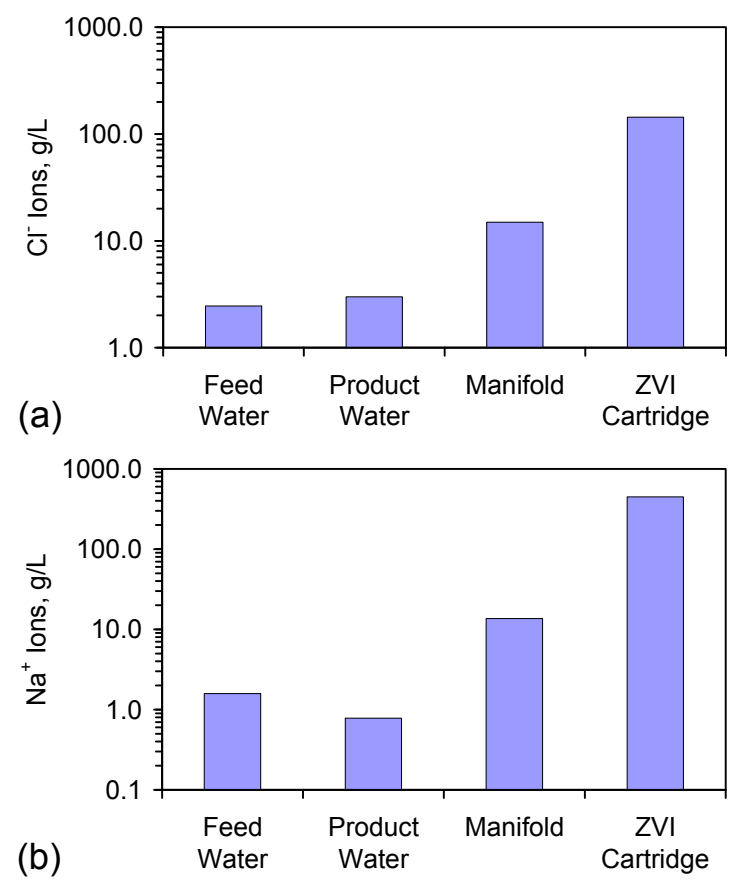

Figure D2. Comparison of ion concentrations from the feed water, product water; manifold water and ZVI cartridge water associated with Trial E143k. (a) $\mathrm{Cl}^{-}$ions; (b) $\mathrm{Na}^{+}$ions. Data source: Table A6. 
The concentration of $\mathrm{Na}^{+}$ions and $\mathrm{Cl}^{-}$ions increases into the manifold and ZVI cartridge (Figure D2, Table A6). This increase is accompanied by preferential $\mathrm{Na}^{+}$ion concentration into the manifold and ZVI cartridge (Figure D2). This example demonstrates that some of the $\mathrm{Na}^{+}$and $\mathrm{Cl}^{-}$ ions, which are removed from the product water (during the desalination process), prior to placement in storage, are retained in the reactor in both the manifold and ZVI cartridge.

\section{Appendix E: Location of the Desalination Sites}

The trial results (Figure 1, Appendix A) have established that ZVI desalination results in a permanent removal of $\mathrm{Na}^{+}$and $\mathrm{Cl}^{-}$ions. The ions are removed separately, resulting in a change in the molar $\mathrm{Na}: \mathrm{Cl}$ ratio in the product water when compared to the feed water (Figure $3 \mathrm{~d}$ ).

\section{E.1. Basic Desalination Model: Observations}

Placement of $\mathrm{NaCl}$ in water will result in the equilibrium reaction:

$$
\mathrm{NaCl}(\mathrm{aq})=\mathrm{Na}^{+}(\mathrm{aq})+\mathrm{Cl}^{-}(\mathrm{aq})
$$

The Gibbs free energy, enthalpy and entropy of each ion is provided in [90]. In a gas-pressured reactor, the following adsorption reactions may occur:

1. During periods of $\mathrm{CO}_{2}$ charging $[2,63]$ :

$$
\begin{gathered}
\mathrm{H}_{2} \mathrm{O}+\mathrm{CO}_{2}=\mathrm{H}_{2} \mathrm{CO}_{3}=\mathrm{HCO}_{3}^{-}+\mathrm{H}^{+} \\
\mathrm{Cl}^{-}+\mathrm{Fe}-\mathrm{O}-\mathrm{O}-(\mathrm{OH})-(\mathrm{OH})+\mathrm{H}^{+}=\mathrm{Fe}-\mathrm{O}-\mathrm{O}-(\mathrm{OH})-\left(\mathrm{OH}_{2}\right)^{+} \cdot \mathrm{Cl}^{-}
\end{gathered}
$$

2. During periods of $\mathrm{O}_{2}$ (air) charging $[2,63]$ :

$$
\begin{gathered}
2 \mathrm{H}_{2} \mathrm{O}+\mathrm{O}_{2}=\mathrm{H}_{2} \mathrm{O}_{2}=2 \mathrm{OH}+2 \mathrm{e}^{-}=2 \mathrm{OH}^{-} \\
\mathrm{OH}^{-}+\mathrm{H}_{2} \mathrm{O}=\mathrm{H}_{2} \mathrm{O}_{2}+\mathrm{H}^{+}+2 \mathrm{e}^{-} \\
\mathrm{Na}^{+}+\mathrm{Fe}-\mathrm{O}-\mathrm{O}-(\mathrm{OH})-(\mathrm{OH})+\mathrm{e}^{-}=\mathrm{Fe}-\mathrm{O}-\mathrm{O}-(\mathrm{OH})-(\mathrm{OH})^{-} \cdot \mathrm{Na}^{+}
\end{gathered}
$$

This model suggests that: (i) $\mathrm{Cl}^{-}$removal is a function of the proton $\left(\mathrm{H}^{+}\right)$availability and will be favoured by acidic conditions; (ii) $\mathrm{Na}^{+}$removal is a function of the electron ( $\mathrm{e}^{-}$) availability and will be favoured by alkaline conditions or conditions containing an excess of $\mathrm{e}^{-}$. The relationship between $\mathrm{pH}$, Eh and ion removal in Figure E1 indicates that $\mathrm{Na}^{+}$and $\mathrm{Cl}^{-}$removal occur in mildly acidic reaction conditions. Their removal increases as the $\mathrm{pH}$ increases between five and seven. This change is associated with a decrease in Eh (indicating electron removal) [63]. Increasing $\mathrm{pH}$ from $\mathrm{pH}$ 5 towards $\mathrm{pH} 7$ decreases the equilibrium $\mathrm{H}_{2} \mathrm{CO}_{3}: \mathrm{HCO}_{3}{ }^{-}$ratio and increases the availability of $\mathrm{H}^{+}$ ions [63]. A strategy that moves the water $\mathrm{pH}$ from a lower value to a higher value will increase the availability of $\mathrm{OH}^{-}$ions, $\mathrm{OH}$. radicals and electrons in the water. These observations are consistent with the desalination reaction involving both protons and electrons. 

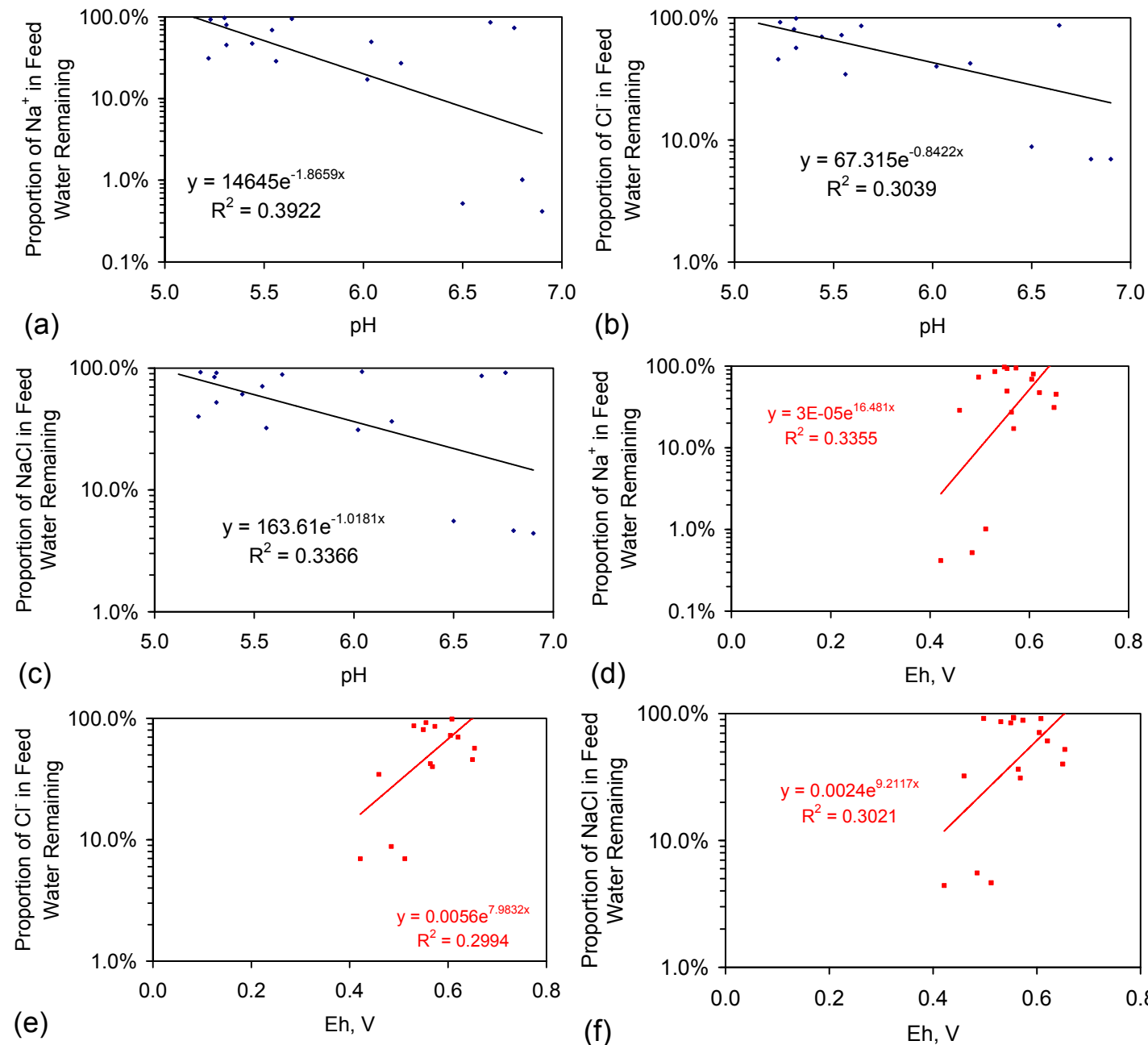

(d)

Eh, V

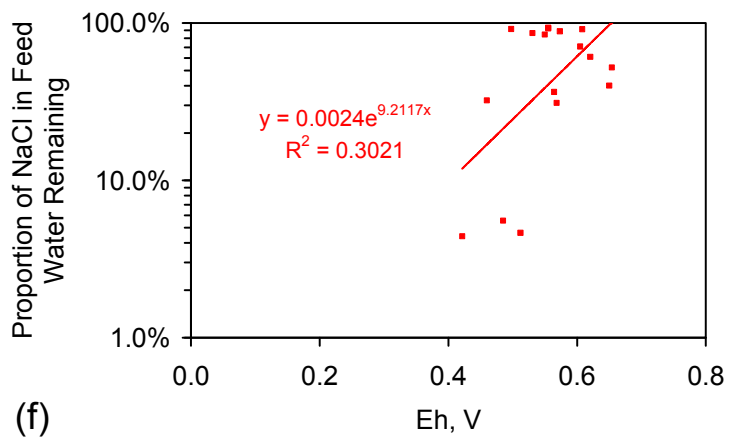

Figure E1. Trial groups: CSD, E143, E144. (a) Proportion of $\mathrm{Na}^{+}$in the feed water remaining in the product water vs. $\mathrm{pH}$ of the product water on removal from the reactor; (b) Proportion of $\mathrm{Cl}^{-}$in the feed water remaining in the product water $v s . \mathrm{pH}$ of the product water on removal from the reactor; (c) Proportion of $\mathrm{NaCl}$ in the feed water remaining in the product water vs. $\mathrm{pH}$ of the product water on removal from the reactor; (d) Proportion of $\mathrm{Na}^{+}$in the feed water remaining in the product water $v s$. Eh of the product water on removal from the reactor; (e) Proportion of $\mathrm{Cl}^{-}$in the feed water remaining in the product water $v$ s. Eh of the product water on removal from the reactor; (f) Proportion of $\mathrm{NaCl}$ in the feed water remaining in the product water $v s$. Eh of the product water on removal from the reactor. Source data in Tables A1-A11 are supplemented with redox data from [2]. Eh analyses are based on a quinhydrone Eh calibration at $\mathrm{pH}=4$ and $\mathrm{pH}=7$; $\mathrm{Eh}, \mathrm{mV}=(-65.667 \mathrm{pH}+744.67+\mathrm{ORP}(\mathrm{mV}))$ : $\mathrm{ORP}=$ oxidation reduction potential, measured with ORP and $\mathrm{pH}$ meters manufactured or branded by Hanna Instruments Ltd., Leighton Buzzard, England, UK, and HM Digital Inc., Culver City, CA, USA.

\section{E.2. Mass Balance Considerations}

The basic adsorption reaction equations (E2,E3) indicate that $2 \mathrm{M}$ of $\mathrm{Fe}^{\circ}$ are required to remove $1 \mathrm{M} \mathrm{NaCl}$. The ZVI cartridge was reused in each sequential trial within a trial group. The ZVI was constructed as follows [2]: CSD trials: $8.4 \mathrm{~L}$ water $+\mathrm{ZVI}\left(224 \mathrm{~g} \mathrm{Fe}^{0}+35 \mathrm{~g} \mathrm{Al}^{0}\right)$; maximum $\mathrm{NaCl}$ removal potential $=0.227 \mathrm{M} \mathrm{NaCl} \cdot \mathrm{L}^{-1}\left(13.31 \mathrm{~g} \mathrm{NaCl}^{-1} \mathrm{~L}^{-1}\right) ; \mathrm{E} 143$ trials: $5.8 \mathrm{~L}$ water $+\mathrm{ZVI}(135 \mathrm{~g}$ $\mathrm{Fe}^{0}+97 \mathrm{~g}$ K-feldspar); maximum $\mathrm{NaCl}$ removal potential $=0.208 \mathrm{M} \mathrm{NaCl} \cdot \mathrm{L}^{-1}\left(12.17 \mathrm{~g} \mathrm{NaCl} \cdot \mathrm{L}^{-1}\right)$; E144 trials: $5.8 \mathrm{~L}$ water $+\mathrm{ZVI}\left(51 \mathrm{~g} \mathrm{Fe}^{0}+90 \mathrm{~g}\right.$ K-feldspar); maximum $\mathrm{NaCl}$ removal potential $=0.0787 \mathrm{M}$ $\mathrm{NaCl} \cdot \mathrm{L}^{-1}\left(4.60 \mathrm{~g} \mathrm{NaCl} \cdot \mathrm{L}^{-1}\right)$. Particle size $=44,000-77,000 \mathrm{~nm} ; \mathrm{ZVI}=$ standard automotive metallic 
paint (and fiberglass) grade powdered (milled) carbon steel; ZVI surface area $=0.00289-0.01732 \mathrm{~m}^{2} \cdot \mathrm{g}^{-1}$. Suppliers: K-Feldspar $=$ Mistral Industrial Chemicals, Antrim, Northern Ireland; $\mathrm{Fe}^{0}=\mathrm{ABL}$ (Stevens) Resin \& Glass, Sandbach, Cheshire, England; $\mathrm{Al}^{0}=\mathrm{ABL}$ (Stevens) Resin \& Glass, Sandbach, Cheshire, England. This information was originally provided in reference [2] and has been reproduced above.

\section{E.2.1. Mass Balance Calculation}

The mass balance takes the form:

$$
\begin{aligned}
\mathrm{Na}^{+}(\text {feed water })\left(\mathrm{g} \cdot \mathrm{L}^{-1}\right) & \left.=\mathrm{Na}^{+}(\text {product water })+\mathrm{Na}^{+} \text {(adsorbed }\right)+\mathrm{Na}^{+}(\text {manifold }+ \text { cartridge }) \\
\mathrm{Cl}^{-}(\text {feed water }), \mathrm{g} \cdot \mathrm{L}^{-1} & \left.\left.=\mathrm{Cl}^{-} \text {(product water }\right)+\mathrm{Cl}^{-} \text {(adsorbed }\right)+\mathrm{Cl}^{-}(\text {manifold }+ \text { cartridge })
\end{aligned}
$$

At the end of each of the CSD and E144 groups of trials, the reactor was completely drained (Figure 2). In the E143 group of trials, some water was retained in the manifold and ZVI cartridge following removal of the product water at the end of each trial.

The observed mass balances were:

1. CSD trial group: total $(\mathrm{g})$ removed: $\mathrm{Na}^{+}=28.23 ; \mathrm{Cl}^{-}=35.42 ; \mathrm{NaCl}$ removed $=54.5 \%$ of $\mathrm{ZVI}$ adsorption potential.

2. E143 trial group: total $(\mathrm{g})$ removed: $\mathrm{Na}^{+}=2.52 ; \mathrm{Cl}^{-}=37.77 ; \mathrm{NaCl}$ removed $=57.3 \%$ of $\mathrm{ZVI}$ adsorption potential; total $(\mathrm{g})$ removed from the product water: $\mathrm{Na}^{+}=49.92 ; \mathrm{Cl}^{-}=55.18$;

3. E144 trial group: total (g) removed: $\mathrm{Na}^{+}=25.88 ; \mathrm{Cl}^{-}=47.98 ; \mathrm{NaCl}$ removed $=277 \%$ of $\mathrm{ZVI}$ adsorption potential.

The operating strategy of leaving residual water in the manifold and ZVI cartridge at the conclusion of each batch trial (E144 series) can result in enhanced concentrations of $\mathrm{Na}^{+}$and $\mathrm{Cl}^{-}$ions in the water within the manifold and ZVI cartridge (Table A6; Figures D1 and D2).

If the adsorption model in Equations (E2) and (E3) is correct, then the mass balance analysis for Trial Group E144 can be interpreted as indicating that the initial stage of the desalination process may be adsorption followed by desorption: i.e.,

$$
\begin{gathered}
\mathrm{Na}^{+}+\mathrm{S}_{1} \leftrightarrow \mathrm{NaS}_{1} \rightarrow \mathrm{B}(\mathrm{Na})+\mathrm{S}_{1} \\
\mathrm{Cl}^{-}+\mathrm{S}_{2} \leftrightarrow \mathrm{ClS}_{2} \rightarrow \mathrm{C}(\mathrm{Cl})+\mathrm{S}_{2} \\
\mathrm{NaO}^{-}+\mathrm{S}_{2} \leftrightarrow \mathrm{NaOS}_{2} \rightarrow \mathrm{C}(\mathrm{NaO})+\mathrm{S}_{2} \\
\mathrm{ClO}^{-}+\mathrm{S}_{2} \leftrightarrow \mathrm{ClOS}_{2} \rightarrow \mathrm{C}(\mathrm{ClO})+\mathrm{S}_{2} \\
\mathrm{H}_{\mathrm{z}} \mathrm{C}_{\mathrm{x}} \mathrm{O}_{\mathrm{n}} \mathrm{Cl}_{\mathrm{y}}^{-}+\mathrm{S}_{2} \leftrightarrow \mathrm{H}_{\mathrm{z}} \mathrm{C}_{\mathrm{x}} \mathrm{O}_{\mathrm{n}} \mathrm{Cl}_{\mathrm{y}} \mathrm{S}_{2} \rightarrow \mathrm{C}\left(\mathrm{H}_{\mathrm{z}} \mathrm{C}_{\mathrm{x}} \mathrm{O}_{\mathrm{n}} \mathrm{Cl}_{\mathrm{y}}\right)+\mathrm{S}_{2} \\
\text { Initial State } \leftrightarrow \text { Adsorbed State (via Step } 1) \rightarrow \text { Product (via Step 2) }
\end{gathered}
$$

$\mathrm{S}_{1}=$ site (Equation (E3)); $\mathrm{S}_{2}=$ site (Equation (E2)); B and C are desorbed products, which permanently remove the ions. The overall adsorption-desorption reaction is complex, and as demonstrated by Equation (E5), specific sites may adsorb, or desorb, both $\mathrm{Na}^{+}$and $\mathrm{Cl}^{-}$ions.

All of the ZVI batches, which have demonstrated partial desalination of water, have either been coated with carbon [5], or incorporate one or more carbon species [1-4], or are derived from carbon steel [2], or have been pre-treated with a carbon species (e.g., $\mathrm{CH}_{4}, \mathrm{CO}, \mathrm{CO}_{2}$ [2]). Fe is known to form catalytic (adsorption-desorption) sites (in the presence of carbon) of the form $\mathrm{Fe}-\mathrm{CCl}_{\mathrm{y}}\left(\mathrm{CH}_{\mathrm{n}}\right)_{\mathrm{x}}$, $\mathrm{Fe}-\left(\mathrm{CH}_{n}\right)_{x}, \mathrm{Fe}-\mathrm{C}\left(\mathrm{CH}_{n}\right)_{x}, \mathrm{Fe}-\mathrm{O}-\left(\mathrm{CH}_{n}\right)_{x}, \mathrm{Fe}-\mathrm{O}-\mathrm{C}\left(\mathrm{CH}_{n}\right)_{x}, \mathrm{Fe}-\mathrm{O}-\mathrm{O}-\mathrm{C}\left(\mathrm{CH}_{n}\right)_{x}$, where $\left(\mathrm{CH}_{n}\right)_{x}$, is an adsorbed group, prior to desorption [81]. The reaction environment in the three groups of trials may have created catalytic sites of the form Fe-CCly, $\mathrm{Fe}-\mathrm{C}, \mathrm{Fe}-\mathrm{O}, \mathrm{Fe}-\mathrm{O}-\mathrm{O}-\mathrm{C}$.

\section{E.3. $p H$ Considerations}

Placement of ZVI in water will result in an initial gradual increase in the $\mathrm{pH}$ of the water with time to a maximum level (e.g., 30-300 days [1,2,26,70,91,92]). The maximum $\mathrm{pH}$ level increases as 
the ZVI:water ratio in the reactor increases [1,2,26,70,91,92]. In an open (e.g., Figure 1) or semi-closed (e.g., Figure 2) diffusion reaction environment, the $\mathrm{pH}$ will subsequently decline to a lower level and approach the initial feed water $\mathrm{pH}[1,2,26,70,91,92]$. The rapidity and magnitude of the $\mathrm{pH}$ rise is a function of ZVI composition [91] and increases as the ZVI concentration (g. $\mathrm{L}^{-1}$ ) increases (e.g., [2]). Comparison of $\mathrm{pH}$ changes with time associated with ZVI trials for a $50 \mathrm{~nm}$ particle size [1] and a $44,000-77,000 \mathrm{~nm}$ particle size $[1,91]$ indicates that the actual ZVI surface area, which is in contact with the water, is not a primary driver of $\mathrm{pH}$ increase. In the CSD, E143 and E144 group trials, the ZVI-water contact surface area was maintained at $0.000314 \mathrm{~m}^{2}\left(\mathrm{CSD}\right.$ group trials $=3.74 \times 10^{-5} \mathrm{~m}^{2} \cdot \mathrm{L}^{-1} ; \mathrm{E} 143$, E144 group trials $=5.42 \times 10^{-5} \mathrm{~m}^{2} \cdot \mathrm{L}^{-1}$ ).

In the CSD, E143 and E144 group trials, carbon dioxide was used to reduce the $\mathrm{pH}$, and air was used to increase the $\mathrm{pH}$ [2]. Figure E1 demonstrates that manipulation of Eh and $\mathrm{pH}$ within the reactor (Figure 2) can optimize $\mathrm{Na}^{+}$and $\mathrm{Cl}^{-}$ion removal.

\section{E.4. Loss of Reactivity with Time}

Zero valent iron $\left(\mathrm{Fe}^{0}, \mathrm{ZVI}\right)$ has been placed in permeable reactive barriers (PRB's) and injected into aquifers in order to effect aquifer remediation since the 1970s (e.g., [6-10,70,71,93-98]). The principle historical remediation focus has been on the removal of organo-chlorides, organo-nitrates, phosphates, nitrates, arsenic and heavy metals (e.g., [26,70,71,93,94,99-102]). An extensive list of the chemicals and microbiota that can be removed by ZVI is documented elsewhere (e.g., [70,71,94-96]).

ZVI corrodes when it is placed in water to produce ferrous (and ferric) oxyhydroxides and ions (e.g., $[1,2,63,64,70,71,93-96,103])$. The corrosion of $\mathrm{Fe}^{0}$ (with time) is catalysed (and accelerated) by the presence of $\mathrm{Cl}^{-}$ions in the water [65,104]. Plugging of porosity (and an associated loss of permeability (e.g., [26])) can result from the ZVI-catalysed (or induced [63]) precipitation of minerals (hydroxides and carbonates) in the ZVI porosity and the development of a hydrogen film on the $\mathrm{Fe}^{0}$ grain surfaces [105].

The precipitated diagenetic products $\left(\mathrm{Fe}(\mathrm{OH})_{x}, \mathrm{FeOOH}\right)$ are hydrated and are more voluminous than the $\mathrm{Fe}^{0}[106,107]$. This volume increase results in a continuous destruction of porosity, deterioration of permeability $\left(k_{p}\right)$ and clogging of $\mathrm{Fe}^{0}$ (PRB's) $[93,99,100]$ and may be accompanied by a loss of reactivity [93].

\section{E.4.1. Porosity Reduction}

Some PRB designers have attempted to overcome the adverse effect of permeability destruction by creating a PRB with a higher initial permeability than the surrounding aquifer [108]. Porosity, $\phi$, reduction in a ZVI PRB can be modelled by assuming a pseudo-first order corrosion reaction and by using hydraulic conductivity $\left(K_{c}\right)$ to represent permeability $\left(k_{p}\right)$ where [109]:

$$
K_{c(t=\mathrm{n})}=K_{c(t=0)}\left(\phi_{(t=0)}-\phi_{(t=\mathrm{n})}\right)^{3} /\left(\left(1-\left(\phi_{(t=0)}+\phi_{(t=\mathrm{n})}\right) /\left(1-\left(\phi_{(t=0)}\right)\right)^{2}\right.\right.
$$

Analysis of ZVI PRBs after one year of operation has established that the bulk of the permeability loss is associated with the upstream entrance face of the PRB, and the reduction in permeability decreases towards the downstream exit face [109]. This progressive reduction in permeability/porosity through the ZVI bed with time has been used to model reactivity, where it is assumed that this change is associated with a loss of reactivity (e.g., [110]).

\section{E.4.2. Impact of ZVI Ageing on Reactivity}

Laboratory experiments have demonstrated [102] that a seven-year-old ZVI PRB, while containing corrosion precipitates, was as effective at remediation as fresh ZVI. The observed reduction in ZVI reactivity with time, associated with PRBs, has been attributed to clogging of the pore space by 
precipitates, or gas discharge from the ZVI, or blocking of the reactive iron surface by precipitates, (e.g., $[111,112])$. Passivation of the Fe surface by Fe ${ }^{\mathrm{III}}$ (oxy)hydroxide coatings has been interpreted as the cause of a loss of reactivity (e.g., [113]). Others have demonstrated that the presence of these coatings is an essential component of ZVI operation (e.g., [1,2,70,71,114-117]). Numerous strategies have been trialed that are designed to mitigate the adverse impact of the progressive destruction of PRB permeability with time (e.g., $[96,118])$.

\section{E.4.3. Impact of ZVI Particle Aggregation on Permeability}

$\mathrm{n}-\mathrm{Fe}^{0}$ studies have demonstrated [119] that the corroding $\mathrm{Fe}^{0}$ particles both aggregate and grow in size (with accreting hydrated (oxy)hydroxides) with time to a stable or equilibrium size. Any increase in particle diameter, $d$, must reduce $\phi$, increase pore tortuosity, $\tau$, and increase the complexity of the pore shape, $\sigma$ [70]. The Hagen-Poiseuille model (e.g., [120-123]) defines the relationship between intrinsic permeability, $k$, and porosity, $\phi$, as:

$$
k=\phi r^{2} / \eta \tau \sigma
$$

where $r$ = pore throat radii, $\eta=$ viscosity of water. The flow between two pores is controlled by the size of the smaller pore [124-126].

\section{E.4.4. Interpretation of the Relationship between Permeability Decline and Reactivity}

Declines in permeability will reduce the amount of water that can flow through the ZVI (in the inter-particle porosity by viscous flow) and must, therefore, reduce the amount of water that can be treated per unit time $[120,126]$. The initial ZVI corrosion products are dominantly-hydrated layered double hydroxides (LDH) (Appendix B). These products contain a high intra-particle porosity (between the LDH cationic layers (Appendix B)), which allows movement of fluids through the particles by Fickian diffusion. Fickian (and non-Fickian) molecular diffusion through the intra-particle porosity of the ZVI corrosion products may account for why some researchers have indicated that the presence of the corrosion coatings is an essential component of ZVI operation (e.g., $[1,2,70,71,114-117])$. The implication is that some ZVI remediation processes are instigated in the inter-particle porosity, while others are instigated in the intra-particle porosity.

This hypothesis indicates that remediation processes, which are dependent on ZVI-water contacts in the inter-particle porosity, are associated with viscous water flow. These processes must show a decline in reactivity, which is related to a decrease in porosity. This is associated with decreases in pore throat radii, increases in pore tortuosity and decreases in permeability (Equation (E7)).

Conversely, remediation processes, which are dependent on intra-particle porosity, will be characterized by Fickian (and non-Fickian) molecular diffusion through the intra-particle porosity. These processes will be largely unaffected by changes in the inter-particle porosity (and viscous flow permeability) of the ZVI.

\section{E.4.5. The Rate Constant, $k$}

A simple test of whether ZVI desalination occurs in the inter-particle porosity or intra-particle porosity is to define the reactivity of the ZVI using the rate constant [27]. The rate constant, $k$, is defined as [27]:

$$
\begin{aligned}
k_{\mathrm{NaCl}} & =\ln \left(\mathrm{NaCl}_{t=0} / \mathrm{NaCl}_{t=\mathrm{n}}\right) / t \\
k_{\mathrm{Cl}} & =\ln \left(\mathrm{Cl}^{-} t=0 / \mathrm{Cl}^{-} t=\mathrm{n}\right) / t \\
k_{\mathrm{Na}} & =\ln \left(\mathrm{Na}^{-}{ }_{t=0} / \mathrm{Na}^{-} t=\mathrm{n}\right) / t
\end{aligned}
$$


$t=$ time, seconds, where $t=0$ is the onset of the trial and $t=\mathrm{n}$ is the conclusion of the trial; $\mathrm{NaCl}=$ concentration of $\mathrm{NaCl}\left(\mathrm{M} \cdot \mathrm{L}^{-1}, \mathrm{M} \cdot \mathrm{L}^{-1}\right) ; \mathrm{Cl}^{-}=$concentration of $\mathrm{Cl}^{-}\left(\mathrm{M} \cdot \mathrm{L}^{-1}, \mathrm{M} \cdot \mathrm{L}^{-1}\right)$; $\mathrm{Na}^{+}=$concentration of $\mathrm{Na}^{+}\left(\mathrm{M} \cdot \mathrm{L}^{-1}, \mathrm{M} \cdot \mathrm{L}^{-1}\right)$.

Increases in $k$ indicate an increase in reactivity, while decreases in $k$ indicate a decrease in reactivity [27].

If the ZVI desalination reaction is confined to the inter-particle porosity, then $k$ will reduce with successive batches of water. If, however, the ZVI desalination reaction is confined to the intra-particle porosity, then $k$ will remain constant (or fluctuate) with successive batches of water.

The rate constant was calculated for each trial grouping (Figure E2). Trial Groups CSD and E144 demonstrated an initial drop in reactivity, which was followed by stabilization and a rise in reactivity with increasing batch number (Figure E2). Trial Group E143 demonstrated a minor decrease in reactivity with increasing batch number (Figure E2b). Trial Groups E143 and E144 also demonstrate that increasing the amount of ZVI in the ZVI cartridge (Figure 2) may increase reactivity (Figure E2).

Reducing the water pressure from $0.01 \mathrm{MPa}$, above atmospheric pressure (CSD, E143, E144) to atmospheric pressure and replacing the gas with air $(120 \mathrm{~L} / \mathrm{h})$, while increasing the reactor size to $240 \mathrm{~L}\left(\mathrm{ZVI}=124 \mathrm{~g} \mathrm{Fe}^{0}+276 \mathrm{~g}\right.$ K-Feldspar) (E146 Trial Group [2]), shows no effective reduction in reactivity with increasing batch number (Figure E2d).
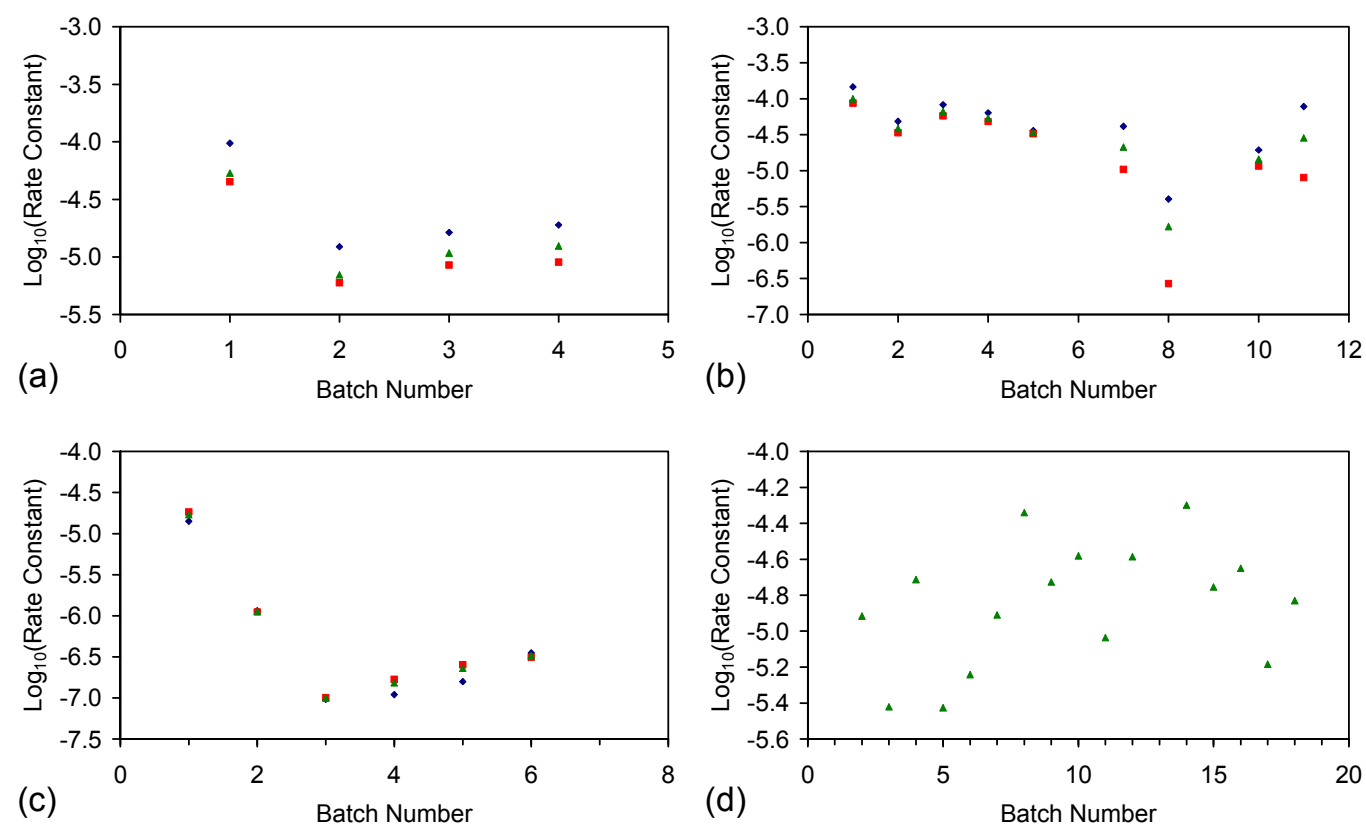

Figure E2. Rate constants. (a) Trial group: CSD; (b) trial group: E143; (c) trial group: E144; (d) trial group: E146 (data source: reference [2]). $\downarrow=\mathrm{Na}^{-} ; \mathbf{\square}=\mathrm{Cl}^{-} ; \boldsymbol{\Lambda}=\mathrm{NaCl}$. E146 Trial Group [2]: batch operation, air flow $=120 \mathrm{~L} \cdot \mathrm{h}^{-1}$. Pressure $=$ atmospheric; non-isothermal temperature $\leqslant 25^{\circ} \mathrm{C}$; reactor capacity $=240$ L; reactor: Figure 2; feed water constructed using halite; E146 ZVI cartridge [2]; cartridge diameter $=20 \mathrm{~mm}$; manifold diameter $=110 \mathrm{~mm}$; energy usage $\leqslant 0.18 \mathrm{~kW} \cdot \mathrm{m}^{-3}$ (during air flows). Further details (including feed salinities, product water salinities, Eh, $\mathrm{pH}, \mathrm{EC}$, air flow rates, duration, temperature, product and feed water UV-visible absorbance profiles ) are provided in reference [2]. 
E.4.6. Control Analysis of the Rate of ZVI Permeability Decline with Time

The viscous flow, inter-particle permeability, $k_{p}$, of the ZVI $\left(44,000-77,000-\mathrm{nm}\right.$ particle size $\left.\left(a_{s i}\right)\right)$ has been measured as a function of time [26] using a vertical ( $\mathrm{z}$ direction) fixed bed reactor and a constant head (or potential, $\Phi$ ) using the basic flux (Darcy) Equation [120]:

$$
\begin{gathered}
Q_{\text {flow }} \text { rate }=\delta / \delta \mathrm{z}\left(k_{\mathrm{p}}(\delta \Phi / \delta \mathrm{z})\right) \\
k_{\mathrm{p}}=Q_{\text {flow rate }} / \Phi
\end{gathered}
$$

$Q_{\text {flowrate }}=$ measured flow rate, $\mathrm{m}^{3} \cdot \mathrm{m}^{-2} \cdot \mathrm{s}^{-1} ; \Phi=$ measured potential, $\mathrm{Pa} ; k_{\mathrm{p}}=$ permeability, $\mathrm{m}^{3} \cdot \mathrm{m}^{-2} \cdot \mathrm{s}^{-1} \cdot \mathrm{Pa}^{-1}$.

Figure E3 provides the change in ZVI permeability with time as a function of time. Following an initial short period of instability, the permeability adopts an exponential decline with time (Figure E3). If the dominant interaction between the ZVI and the water is via the inter-particle porosity, then the reactivity would be expected to reduce sharply after the ZVI had been saturated for about $100 \mathrm{~h}$ (Figure E3). The CSD and E144 trials (Figure E2) show an initial reduction in reactivity, which could be attributed to the initial instability in ZVI permeability (Figure E3).

A characteristic of inter-particle flow of water through ZVI is a major increase in $\mathrm{pH}$ and decrease in Eh in the product water (Figure E3a). These major redox changes were not observed in the CSD, E143 or E144 trials.
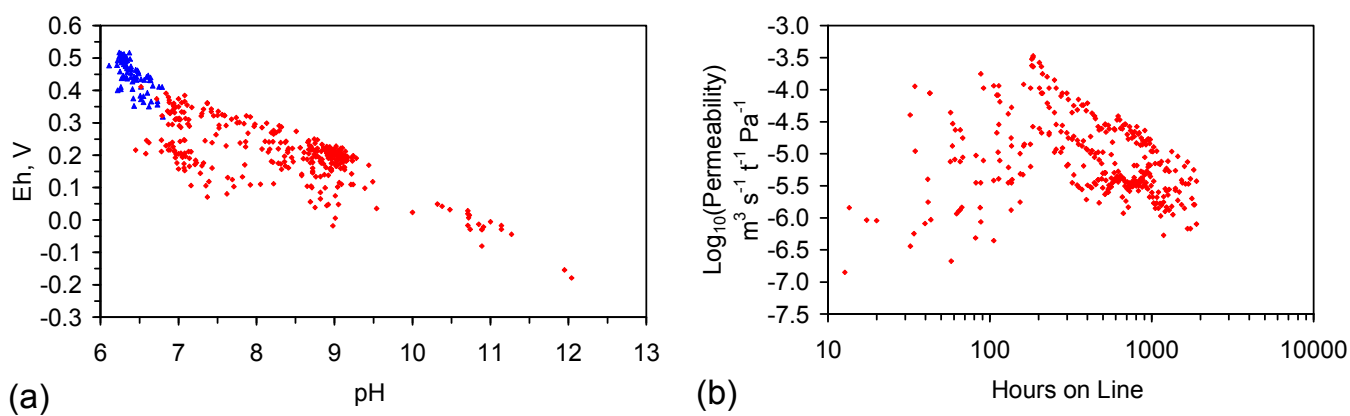

Figure E3. (a) Eh vs. pH ( $\boldsymbol{\Delta}$ = feed water; $\$$ =product water); (b) Permeability vs. hours on line. Reactor type: packed bed: number of columns: three (arranged in parallel): column length: $0.5 \mathrm{~m}$; column diameter: $40 \mathrm{~mm}$; material: medium density polyethylene (MDPE); entrance conduit: $15 \mathrm{~mm}$ OD (outer diameter); exit conduit: $15 \mathrm{~mm}$ OD; flow measurement point: at the exit conduit for each column; continuous flow duration: 79 days; water used: fresh water (Section 2.3): $\mathrm{EC}=0.3 \mathrm{mS} \cdot \mathrm{cm}^{-1}$; typical feed water cation and anion analysis: Section 2.3; reactor: orientation = vertical; flow direction: from base to top; constant potential $(\Phi)$ : $7500 \mathrm{~Pa} ; \mathrm{ZVI}=0.5 \mathrm{~kg} /$ column; $\left[a_{s i}\right]=44,000-77,000 \mathrm{~nm}$ particle size; ZVI retention material: filter wool; redox properties measured: $\mathrm{Eh}, \mathrm{pH}$; $\mathrm{pH}$ calibration: $\mathrm{pH}=4,7,10$; Eh calibration: quinhydrone calibration at $\mathrm{pH}=4$ and $\mathrm{pH}=7$. Further details about the methodology and apparatus used for ZVI flow testing are provided in reference [26].

\section{E.4.7. Intra-Particle or Inter-Particle Location of the ZVI Desalination Sites}

If $k$ is controlled by the inter-particle mass transport of the ions to the ZVI-water interface, then the proportion of available adsorption sites will decrease with time. The reactivity will decline, as the fraction of available sites, $\omega$, decreases, as [127]:

$$
k t=\mathrm{b}\left(1-(1-\omega)^{\mathrm{a}}\right)
$$

where $\mathrm{a}$ and $\mathrm{b}$ are constants. The rate constant data in Figure E2 are not consistent with a hypothesis that the reactivity declines with time (i.e., $\mathrm{a}=1 ; \mathrm{b}=k t ; \omega=0$ ). Figure E3 demonstrates that if the 
desalination reaction is dominated by inter-particle sites (and if Equations (E6), (E7) and (E10) apply), then the reactivity will decline rapidly with successive batches.

\section{E.4.8. Intra-Particle Location of the ZVI Desalination Sites}

If the hypothesis that the ZVI desalination sites are located in the intra-particle porosity of LDH structures is correct, then this hypothesis can be tested by sustained reuse of a ZVI cartridge. Two ZVI cartridges were selected to test this hypothesis: (i) the E143 ZVI cartridge [2]; and (ii) the E146 ZVI cartridge [2].

\section{E143 ZVI Cartridge Reuse}

Following the conclusion of Trial E143k, the reactor was drained and the ZVI cartridge rinsed. The cartridge was returned to the reactor (Figure 2), and the trials were repeated using a higher salinity feed water, in order to accelerate any decline in the availability of sites. The trial results (Figure E4) show an initial increase in reactivity with batch number, which is followed by a steep decline in reactivity with batch number. Given the large time interval between placement of the ZVI in an aqueous environment and the start of the reactivity decline ( $>60$ days), it is unlikely that a ZVI permeability decline (Figure $3 \mathrm{~b}$ ) is responsible for the observed decline in reactivity (Figure E4a). The sharp decline could be modelled using Equation (E10) and is interpreted as indicating that the desalination sites (Equation (E5)) have been progressively deactivated.

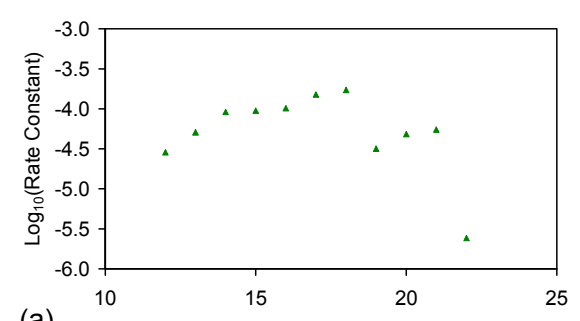

(a)
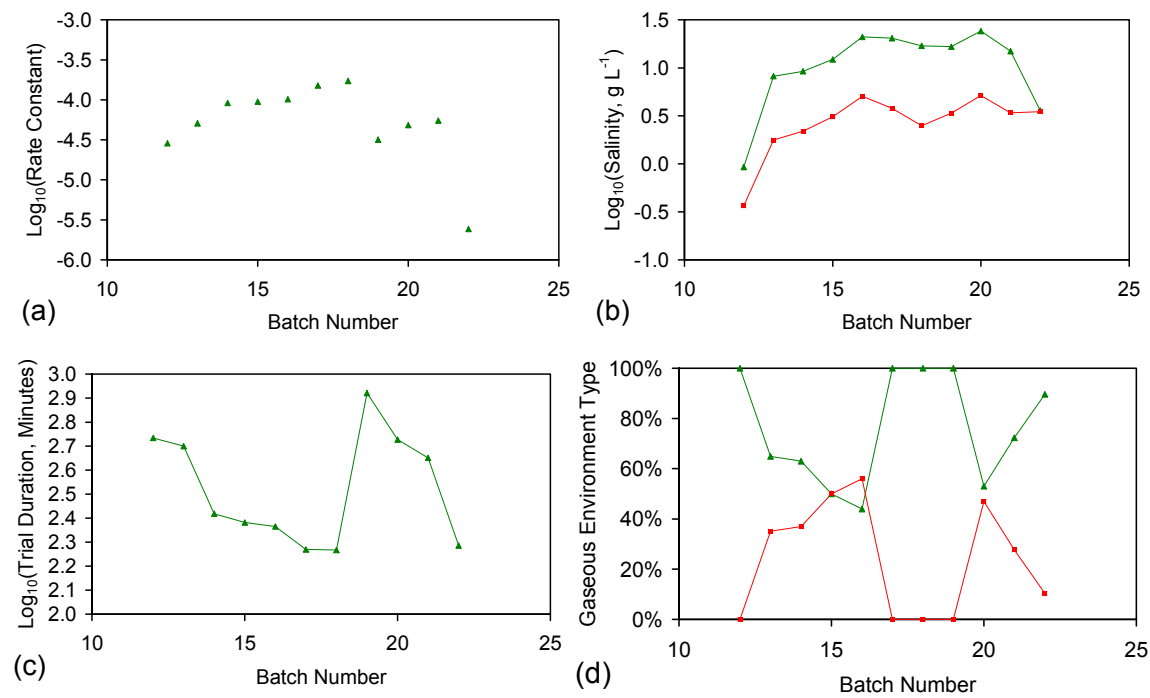

Figure E4. E143 trial group (Trials E1431-E143v). (a) Rate constant vs. batch number; (b) salinity vs. batch number, $\mathbf{\square}$ = product water; $\mathbf{\Lambda}=$ feed water; (c) trial duration $v$ s. batch number; (d) ((charging gas type $\times$ duration)/total duration) vs. batch number. $\mathbf{\square}=\mathrm{CO}_{2} ; \boldsymbol{\Delta}=$ air. Batch operation, air flow $=13.2 \mathrm{~L} \cdot \mathrm{h}^{-1} . \mathrm{CO}_{2}$ flow $=3.3 \mathrm{~L} \cdot \mathrm{h}^{-1}$. Pressure $=$ atmospheric $+0.01 \mathrm{MPa}$; non-isothermal temperature $=4.3-11.1^{\circ} \mathrm{C}$; reactor capacity $=5.8 \mathrm{~L}$; reactor: Figure 2; feed water constructed using $\mathrm{NaCl}$; E143 ZVI cartridge [2]; cartridge diameter $=20 \mathrm{~mm}$; manifold diameter $=40 \mathrm{~mm}$; energy usage $\leqslant 0.18 \mathrm{~kW} \cdot \mathrm{m}^{-3}$ (during air flows); salinity measurement: ion selective electrodes. Further details about the apparatus and methodology are provided in reference [2].

\section{E146 ZVI Cartridge Reuse}

The E146 trial group ZVM cartridge [2] (Figure E2d) was reused to process $20 \times 240$ L batches of water and $12 \times 140 \mathrm{~L}$ batches of water (Figure E5). The rate constant maintained a constant value between batches (Figure E5). The abrupt decrease in the rate constant for $\mathrm{Cl}^{-}$removal after the cartridge was switched to a smaller reactor unit is interpreted as indicating that: (i) the higher air:water 
ratio increased the availability of $\mathrm{NaO}^{-}$; and (ii) $\mathrm{NaO}^{-}$was able to preferentially compete with $\mathrm{Cl}^{-}$ for the available sites. The constant value of $k$ with successive batches is interpreted as indicating that the ZVI desalination sites are located in the intra-particle porosity.
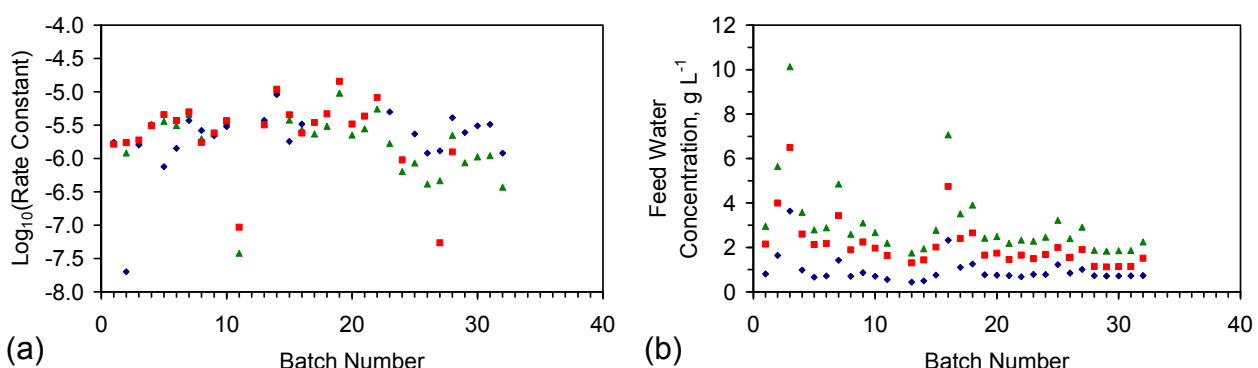

Figure E5. E146 cartridge (E147 trial series). (a) Rate constant $v$ s. batch number; (b) feed water concentrations $v s$. batch number. Batch operation, air flow $=140 \mathrm{~L} \cdot \mathrm{h}^{-1}$. Pressure $=$ atmospheric; non-isothermal temperature $=5-25{ }^{\circ} \mathrm{C}$; Reactor A capacity $=240 \mathrm{~L}$ (Batches 1-20); Reactor B capacity $=140$ L (Batches 21-32); reactor: Figure 2; feed water constructed using Zechstein halite; E146 ZVI cartridge [2] reused following nine months storage; cartridge diameter $=40 \mathrm{~mm}$; manifold diameter $=110 \mathrm{~mm}$. The manifold and cartridge were drained at the end of each trial; energy usage $\leqslant 0.18 \mathrm{~kW} \cdot \mathrm{m}^{-3}$; salinity measurement: ion selective electrodes. $\boldsymbol{\nabla} \mathrm{Na}^{-} ; \mathbf{\square}=\mathrm{Cl}^{-} ; \boldsymbol{\Delta}=\mathrm{NaCl}$. Further details about the apparatus and methodology are provided in reference [2].

The constant values of $k$ (Figures E2, E4 and E5) as a function of batch number are consistent with the hypothesis that: (i) the ZVI catalyses the desalination reaction; (ii) the desorbed desalination products are retained in the reactor or ZVI.

\section{Appendix F: Nature of the Reacted (Catalytic) ZVI Material}

A commercial-grade ZVI catalyst for desalination will be expected to process many $\mathrm{m}^{3}$ of water for each tonne of ZVI [128]. The E143 trials demonstrated (Figures E2b and E4) that $1 \mathrm{t} \mathrm{Fe}{ }^{0}$ could be expected to process more than $945 \mathrm{~m}^{3}$ of water [2]. The E146 trials demonstrated (Figures E2d and E5) that $1 \mathrm{t} \mathrm{Fe}^{0}$ could be expected to process more than $52,000 \mathrm{~m}^{3}$ of water [2]. Catalysts are assessed [128] in terms of their: (i) activity (ability to convert a feedstock (saline water) to a product (partially-desalinated water) in a timely manner (e.g., Equation (E2) (Figures E2, E4 and E5))); (ii) selectivity (ability to give the desired product (i.e., partially-desalinated water)); (iii) life expectancy (time period (or number of batches) over which the catalyst maintains a satisfactory level of activity).

\section{F.1. Catalyst}

The function of a catalyst is to take a reaction that has a high energy barrier and to create an alternative reaction route to produce the required product (Figure F1a) [27,128].

The desalination reaction is considered to be a multi-stage reaction (e.g., Equation (E5)) where $\mathrm{Na}^{+}$ and $\mathrm{Cl}^{-}$ions follow separate removal routes. The schematic energy profile for a multi-stage reaction of this type is summarized in Figure F1b. Each step in the multi-stage reaction is associated with an energy barrier that has to be overcome (Figure F1b).

Step 2 (Equation (E5)) is rate determining, such that $k_{\text {Step } 1} \gg k_{\text {Step } 2}$. Therefore, the intermediate adsorbed ions (Step 1) are more likely to disassociate as $\mathrm{Cl}^{-}$ions or $\mathrm{Na}^{+}$ions than to form products, i.e., [129]:

$$
\begin{gathered}
\text { Forward Step } 1=\mathrm{Cl}^{-}+\mathrm{S}_{1} \rightarrow \mathrm{ClS}_{1} \text { Rate, } v_{1 f}=k_{1 f}\left[\mathrm{Cl}^{-}\right]\left[\mathrm{S}_{1}\right] k_{1 f}=A_{1 f} \exp \left(-E_{1 f} / R T\right) \\
\text { Reverse Step } 1=\mathrm{ClS}_{1} \rightarrow \mathrm{Cl}^{-}+\mathrm{S}_{1} \text { Rate, } v_{1 r}=k_{1 r}\left[\mathrm{ClS}_{1}\right] k_{1 r}=A_{1 r} \exp \left(-E_{1 r} / R T\right) \\
\text { Forward Step } 2=\mathrm{NaS}_{1} \rightarrow \mathrm{C}(\mathrm{Cl})+\mathrm{S}_{1} \text { Rate, } v_{2}=k_{2}\left[\mathrm{ClS}_{1}\right] k_{2}=A_{2} \exp \left(-E_{2} / R T\right)
\end{gathered}
$$


where subscripts 1,2 refer to specific steps; subscript $f$ refers to adsorption; and $r$ refers to desorption to the initial reactant state (i.e., $\mathrm{Cl}^{-}$); $E=$ activation energy; $A=$ frequency (or pre-exponential) factor.

Prior to Step 1, the system has an initial energy level (e.g., zero; Figure F1b) and requires an energy of $E_{1 f}$ in order to produce the adsorbed species $\mathrm{ClS}_{1}$ (Figure F1b). The enthalpy $\left(\Delta H_{1}\right)$ represents the net change in energy associated with the formation of the adsorbed species $\left(\mathrm{ClS}_{1}\right)$. The formation of the permanently-removed product $(\mathrm{C}(\mathrm{Cl}))$ requires an energy $E_{2}$ (Figure F1b). The apparent activation energy, $E_{a}, E_{b}$ (Figure F1b) for the removal of $\mathrm{Cl}^{-}$is:

$$
E_{a}, E_{b}=E_{2}+\Delta H_{1}
$$

If $E_{2}+\Delta H_{1}<0$, then $E_{a}$ will be negative, and the rate of desalination will increase with decreasing temperature. If $E_{2}+\Delta H_{1}>0$, then $E_{b}$ will be positive, and the rate of desalination will increase with increasing temperature.

In a multi-step reaction, the measurable activation energy from a plot of $\log (k) v s .1 / T$ [27] is either $E_{a}$ or $E_{b}$ (Figure F1b).

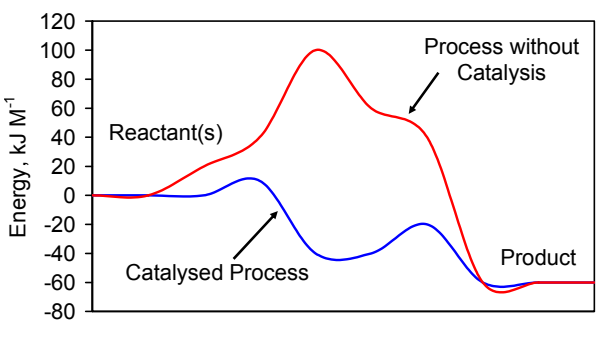

(a)

Reaction Co-ordinate

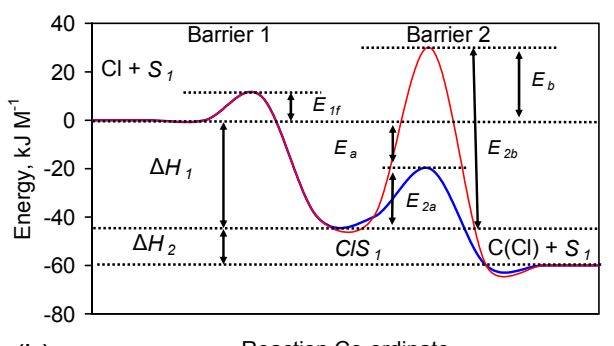

(b)

Reaction Co-ordinate

Figure F1. Schematic energy profile for desalination. (a) Catalyst concept; (b) multi-stage adsorption-desorption profile. $E_{a}=$ measurable apparent activation energy if $k$ increases with reducing temperature. $E_{b}=$ measurable apparent activation energy if $k$ increases with increasing temperature.

\section{F.2. Fe Catalyst}

$\mathrm{Fe}^{0}$ and its related $\mathrm{Fe}^{2+}$ and $\mathrm{Fe}^{3+}$ species are long-established catalysts in both an aqueous and a gaseous environment for a number of reactions (e.g., [130-133]). Historically, the key component in a $\mathrm{Fe}^{0}$ catalyst is carbon. This is held as one or more of $\mathrm{C}^{0}, \mathrm{Fe}_{\mathrm{x}} \mathrm{C}_{\mathrm{y}}, \mathrm{Fe}_{\mathrm{x}} \mathrm{C}_{\mathrm{y}} \mathrm{O}_{\mathrm{z}}, \mathrm{Fe}_{\mathrm{x}} \mathrm{C}_{\mathrm{y}} \mathrm{H}_{\mathrm{z}}, \mathrm{Fe}_{\mathrm{x}} \mathrm{C}_{\mathrm{y}} \mathrm{H}_{\mathrm{z}} \mathrm{O}_{\mathrm{y}}$, $\mathrm{Fe}_{\mathrm{x}} \mathrm{C}_{\mathrm{y}} \mathrm{H}_{\mathrm{z}} \mathrm{Cl}_{\mathrm{y}}$, e.g., [81]. More recently, it has been discovered that layered double hydroxides (LDH) are effective catalysts [133]. The LDH generic grouping includes green rusts, $\mathrm{FeOOH}$ species and their amorphous iron hydroxide precursors (Appendix B). LDH have the general structure $[70,71,133]$ :

$$
\left[\mathrm{M}_{1-\mathrm{x}}^{\mathrm{II}} \mathrm{M}_{\mathrm{x}}^{\mathrm{III}}(\mathrm{OH})_{\mathrm{n}}\right]^{\mathrm{x}+} \mathrm{A}^{\mathrm{x}-} \mathrm{mH}_{2} \mathrm{O}
$$

where $\mathrm{M}=$ a cation (they can include $\mathrm{M}^{\mathrm{I}}$ and $\mathrm{M}^{\mathrm{IV}}$ species [70,71]); and $\mathrm{A}=$ an anion. They form positively-charged brucite-like layers, which are separated by negatively-charged anion-rich inter-layers [133]. The LDH are an intermediate diagenetic product, where the final equilibrium crystallized product may be $\mathrm{Fe}_{\mathrm{x}} \mathrm{O}_{\mathrm{y}}$, or $\mathrm{FeOOH}$, or $\mathrm{FeCO}_{3}[63,64]$. Their activity is a function of the electrochemical current density and their capacitance, e.g., [133]:

$$
\text { Activity (turnover frequency, } \mathrm{s}^{-1} \text { ) }=i N_{A} / 4 F N_{\text {atoms }}=\mathrm{J} / 4 \mathrm{C}
$$

$i=$ current; $N_{\text {atoms }}=$ number of active sites; $F=$ Faraday constant; $N_{A}=$ Avogadro constant; $J=$ current density (energy densities of $100 \mathrm{~W} \mathrm{~kg} \cdot \mathrm{h}^{-1}$ have been recorded [2] in the fresh ZVI catalyst prior to use. This reduces [2] during desalination to $0.0006-16.7 \mathrm{~W} \mathrm{~kg} \cdot \mathrm{h}^{-1}$ ); $C=$ capacitance (capacitance of $300 \mathrm{~F} \cdot \mathrm{g}^{-1}$ has been recorded [2] in the ZVI catalyst prior to use; this reduces [2] during desalination 
to $10-20,000 \times 10^{-6} \mathrm{~F} \cdot \mathrm{g}^{-1}$ ). Activity levels (ST trial series [2]) can reduce during desalination by a factor of $10^{-5}$ [2]. The effective cessation of catalytic activity is associated with a decrease in $J$ and $C$ [2]. reference [2] placed the desalination trials into a number of groups which reflected the composition of the ZVI, delivery of the ZVI into the reaction environment and operating conditions. In this study the trial notation system and definitions used in reference [2] has been retained for the ST trial series, CSD Trial Series, E143 Trial Series, E144 Trial Series and E146 Trial Series.

The most common form of $\mathrm{LDH}$ occurs as $\mathrm{M}_{1-x} \mathrm{Fe}_{\mathrm{x}}(\mathrm{OOH})$ oxyhydroxide films or coatings on ZVI particles and surfaces within a reaction environment [2]. This structuring allows the ZVI to actively remove divalent and trivalent cations from the water [2] and convert them into effective catalysts [133]. Both oxygen evolution $[26,70,134]$ and hydrogen evolution $[1,70,71,105,108,109,134-138]$ have been associated with the placement of ZVI in water.

\section{F.3. Krasilshchikov Pathway}

Trial E143k established (Table A6, Appendix D) that the water immediately above the ZVI was depleted in anions $\left(\mathrm{Cl}^{-}\right)$and enriched in $\mathrm{Na}^{+}$. The high $\mathrm{Na}^{+}$concentration associated with acidic conditions [2] is indicative of the presence of $\mathrm{NaO}^{-}$. This may form in accordance with the Krasilshchikov pathway [133,138]:

$$
\begin{gathered}
\mathrm{Na}^{+}+\mathrm{OH}^{-}=\mathrm{NaOH} \\
\mathrm{NaOH}+\mathrm{OH}^{-}=\mathrm{NaO}^{-}+\mathrm{H}_{2} \mathrm{O} \\
\mathrm{NaO}^{-}=\mathrm{NaO}+\mathrm{e}^{-}
\end{gathered}
$$

The presence of $\mathrm{NaO}^{-}$has been specifically identified in product water extracted from a reactor (E146 trial series [2]). The high concentrations of $\mathrm{Na}^{+}$in water drained from the ZVI cartridge (Table A6), implies that the ZVI is operating an auto-reductive process of the form [133]:

$$
\begin{gathered}
\mathrm{Me}+\mathrm{OH}^{-}=\mathrm{Me}-\mathrm{OH}+\mathrm{e}^{-} \\
\mathrm{Me}-\mathrm{OH}+\mathrm{OH}^{-}=\mathrm{Me}-\mathrm{O}^{-}+\mathrm{H}_{2} \mathrm{O} \\
\mathrm{Me}-\mathrm{O}^{-}=\mathrm{Me}-\mathrm{O}+\mathrm{e}^{-} \\
2 \mathrm{Me}-\mathrm{O}=2 \mathrm{Me}+\mathrm{O}_{2}
\end{gathered}
$$

where Me is the active site of the $\mathrm{LDH}$. The net effect of the Krasilshchikov pathway is to increase the $\mathrm{H}^{+}: \mathrm{OH}^{-}$molar ratio associated with the ZVI (i.e., decrease its $\mathrm{pH}$ ). This can result in lower $\mathrm{pH}$ values being associated with the ZVI cartridge (e.g., E143k $=5.15$ on extraction [2]; 6.48 after four weeks of storage in contact with air [2]) than in the associated product water (e.g., E143k $=6.04$ on extraction [2]; 6.34 after four weeks of storage in contact with air [2]).

The $\mathrm{LDH}$ is a very effective $\mathrm{O}_{2}$-producing catalyst, which shows excellent long-term stability with no appreciable degradation after $7000 \mathrm{~h}$ of operation (at a current density of $10 \mathrm{MA} \cdot \mathrm{cm}^{-2}$ ) [139]. The $\mathrm{LDH}$ catalyst is insensitive to the relative ratio of $\mathrm{M}^{\mathrm{II}}: \mathrm{M}^{\mathrm{III}}$ in the LDH [139]. The Me-O adopts a "rock salt" structure, which allows substitutional incorporation of Fe ${ }^{\mathrm{III}}$ [140].

\section{F.4. ZVI Desalination Catalyst}

The initial batch trials of fresh ZVI (44,000-77,000-nm particle size) established that no effective desalination occurred when ZVI was placed in saline water [1,91]. Impregnation of the ZVI using the "incipient wetness technique and impregnation by soaking technique" with $\mathrm{CH}_{4}, \mathrm{CO}$ and $\mathrm{CO}_{2}$ [2] resulted in the formation of $\mathrm{Fe}_{\mathrm{x}} \mathrm{C}_{\mathrm{y}}, \mathrm{Fe}_{\mathrm{x}} \mathrm{C}_{\mathrm{y}} \mathrm{O}_{\mathrm{z}}, \mathrm{Fe}_{\mathrm{x}} \mathrm{C}_{\mathrm{y}} \mathrm{H}_{\mathrm{z}}, \mathrm{Fe}_{\mathrm{x}} \mathrm{C}_{\mathrm{y}} \mathrm{H}_{\mathrm{z}} \mathrm{O}_{\mathrm{y}}$ catalytic sites within the ZVI. The ZVI was then sheathed and pelleted [2]. The IUPAC (International Union of Pure and Applied Chemistry) general procedure for catalyst formulation [141] was used [2]. 
The pre-use (and operational) characteristics of the ST group series [2] ZVI desalination catalyst are its energy density (e.g., $<100 \mathrm{~W} \mathrm{~kg} \cdot \mathrm{h}^{-1}$ [2]), capacitance (e.g., $<300 \mathrm{~F} \cdot \mathrm{g}^{-1}$ [2]), surface charge (e.g., $-0.02-0.18 \mathrm{C} \cdot \mathrm{m}^{-2}$ [2]) and observed operational surface area (e.g., $20-120 \mathrm{~m}^{2} \cdot \mathrm{g}^{-1}$ [2]) determined as a function of proton uptake and $\mathrm{pH}$ [2].

\section{F.4.1. Initial ZVI Desalination Catalyst Operation}

Placement of the ZVI catalyst, constructed using 44000-77,000 nm particle-sized $\mathrm{Fe}^{0}$ (termed ZVM TP [2]) into a static body of saline water (Figure 1) at ambient temperatures (non-isothermal temperature range $=-10-25^{\circ} \mathrm{C}$ ) resulted in desalination occurring with a consistent rate constant (Figure F2a). Examples of the catalyst pellets are provided in Figure F3. ZVP TP is the generic term used in reference [2] to describe ZVI which has been processed by the "incipient wetness technique and impregnation by soaking technique" [141] to form a water treatment and desalination catalyst.

PVP (polyvinylpyrrolidone)-impregnated n-Fe $\left(50 \mathrm{~nm}, 20 \mathrm{~m}^{2} \cdot \mathrm{g}^{-1}\right.$ surface area), which was coated with tetraethyl orthosilicate, was trialed [1] before and after impregnation using the "incipient wetness technique and impregnation by soaking technique" [141]. The trial established that following impregnation, the amount of $n-\mathrm{Fe}^{0}$ required to achieve a specific rate constant (Figure F2b) in a static body of water (Figure 1) could be reduced from $25 \mathrm{~g} \cdot \mathrm{L}^{-1}$ (Reactors 9, 10, 11 [1]) to $0.1-0.2 \mathrm{~g} \cdot \mathrm{L}^{-1}$ (Reactors 13, 14 [1]).


Figure F2. Initial ZVI catalyst formulation trials. (a) ST1a to ST5j ( $)+$ ST6 (ם) trials vs. feed water salinity. ST6 reused pellets. Data: [2]. (b) reactors 9, 10,11 ( $)+$ reactors 13, $14(\boldsymbol{\square})$. Data: [1]. Further information about the trials, reactors, trial duration, feed water and product water parameters $(\mathrm{Eh}, \mathrm{pH}$, EC, salinity) temperature, ZVI concentration and desalination as a function of time are provided in references $[1,2]$.
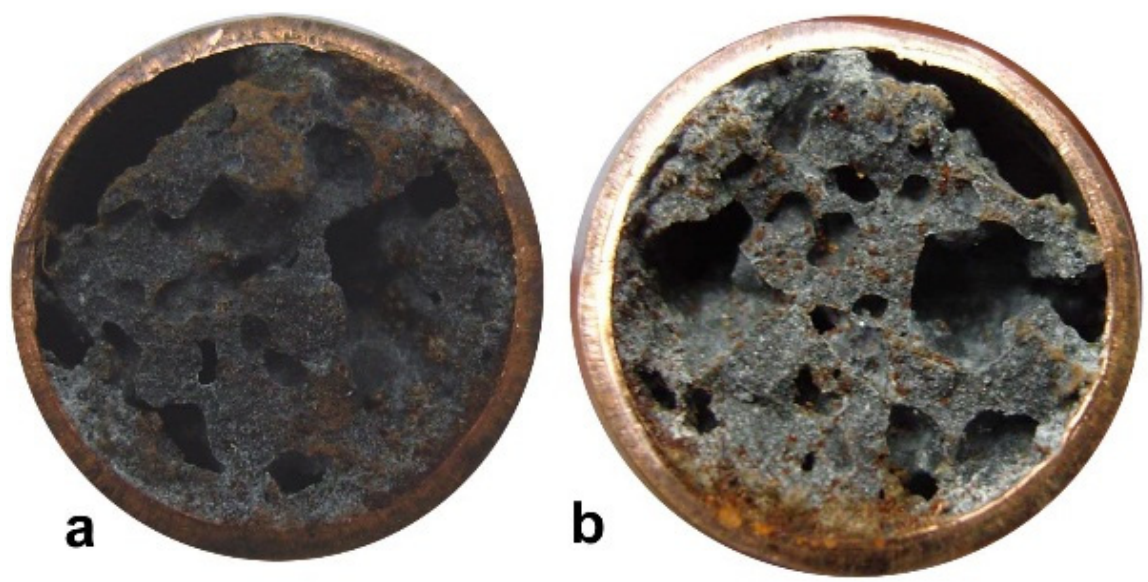

Figure F3. Examples of ZVM TP catalytic desalination pellets (ST trial group series [2]). (a) Example A; (b) Example B. Both pellets have a 15-mm outer diameter. 


\section{F.4.2. Gas-Pressured ZVI Desalination Catalyst Operation}

The initial trials used a simple reactor (Figure 1) and demonstrated that the partial desalination of water could be catalysed by a Fe ${ }^{\circ}$-derived catalyst (Figures F2 and F3). Desalination ceased when the residual energy density, capacitance and surface charge dropped below critical limits [2]. If the desalination process is catalytic and is driven by the availability of protons and electrons (i.e., energy density, capacitance and surface charge), then it is reasonable to expect that provision of a source of protons and electrons to the water will result in either recharge of the catalyst or a reduction in the rate of deterioration of the catalyst.

This hypothesis was tested in the Trial Series CSD, E143, E144 and E146 [2]. These trials used a gas source to create a fresh source of protons and electrons in the water (Equations (E2) and (E3)).

The ST trials [2] and the n-Fe ${ }^{0}$ [1] trials (Figure F2) established that there was a high probability that the desalination reaction is a catalysed reaction as opposed to a conventional adsorption reaction [3-5]. This interpretation is supported by the trial data in Figures E2, E4 and E5. Specific points are:

1. The raw ZVI (44,000-77,000 nm particle size) shows no desalination properties if it is placed in saline water and is left for a period of 30-300 days, e.g., [1,91];

2. Processed ZVI constructed [2] using the "incipient wetness technique and impregnation by soaking technique" [141] provides (Figure F2a) a single-use application for the desalination of water tanks (Figure 1). Reuse of the ZVM TP without recharge (ST6 trials (Figure F2a) [2]) results in a lower rate constant.

3. ZVI constructed with ion exchange material $[2,26]$ coupled with an "impregnation by soaking technique" [2,141] and proton and electron recharge (Trials CSD, E143, E144, E146) demonstrated multiple use for desalination without a major loss of activity (Figures E2, E4 and E5).

These observations are interpreted as indicating that:

1. The desalination process is catalytic;

2. The desalination catalytic sites are located in the intra-layer porosity of LDH and related species;

3. The desalination process involves electrons (e.g., CSD, E143, E146 trial series (Figures E2, E4 and E5);

4. The desalination process can involve both electrons and protons (e.g., CSD, E143, E144, E146 trial series (Figures E2, E4 and E5);

5. The catalyst can be recharged during the desalination process by providing an appropriate gas charge at an appropriate pressure.

\section{Appendix G: Composition Characteristics of Suitable Saline Water}

Water can be characterized [142] in terms of: (1) the master variables: (i) $\mathrm{pH}$ $\left(\mathrm{pH}=-\log _{10}\left[\mathrm{H}^{+}\right]\right)[27]$; and (ii) pe (pe $\left.=-\log _{10}\left[\mathrm{e}^{-}\right]=\mathrm{Eh} /(2.3 R T / F)\right)[27,142]$ (e.g., Figures E1 and E3a). $F=$ Faraday constant; (2) the main physiochemical parameters.

The main physiochemical characteristics are:

(i) Total dissolved solids (TDS). This is normally measured using EC (electrical conductivity) where TDS $=f$ EC where $f$ and EC vary with temperature [142]. A value for $f$ of 0.55 is commonly used to determine the TDS of water containing $\mathrm{NaCl}$ and 0.75 for water dominated by calcium carbonate [142]. The EC of water produced during ZVI desalination can be higher than the EC of the feed water $[2,3]$. 
(ii) The major ions. The major ions fall into two groups (anions and cations). Common practice is to determine the cation and anion concentrations and an ionic balance error [142], e.g.:

$$
\begin{gathered}
\mathrm{PC}=\text { Principal Cations }\left(\text { meq } \cdot \mathrm{L}^{-1}\right)=\mathrm{Na}^{+} / 22.99+2 \mathrm{Ca}^{2+} / 40.08+2 \mathrm{Mg}^{2+} / 24.31+\mathrm{K}^{+} / 39 \\
\mathrm{PA}=\text { Principal Anions }\left(\text { meq. } \mathrm{L}^{-1}\right)=\mathrm{Cl}^{-} / 35.45+2\left(\mathrm{SO}_{4}^{2-}\right) / 96.06+\mathrm{NO}_{3}^{-} / 62+\text { Alkalinity } \\
\text { Ion Balance Error }(\mathrm{IBE})=(\mathrm{PC}-\mathrm{PA}) /(\mathrm{PC}+\mathrm{PA}) \times 100 \%
\end{gathered}
$$

The concentration of trace components, such as Se or As, can be significant when assessing the suitability of water for irrigation [142]. Alkalinity is commonly expressed as meq. $\mathrm{L}^{-1} \mathrm{CaCO}_{3}$ or $\mathrm{HCO}_{3}{ }^{-}$.

All of the feed water samples used natural spring water (Section 2.3 and Figure E3a) as a base. Trial Groups CSD and E143 added chemically-pure $\mathrm{NaCl}$ to this spring water [2]. This saline water is characterized by a major UV-visible absorbance peak at $225 \mathrm{~nm}$ and may have minor absorbance peaks at 215 and $285 \mathrm{~nm}$. Trial Groups E144 and E146 added natural Zechstein halite to this spring water [2]. The associated UV-visible absorbance peaks are documented in reference [2].

The analyses in Figures 1d and E5a and Appendix A demonstrate removal of both $\mathrm{Na}^{+}$and $\mathrm{Cl}^{-}$ ions, with preferential removal of $\mathrm{Na}^{+}$ions. The net effect is a reduction in PC, PA and IBE. The Trial Groups CSD, E143 and E144 all had $\mathrm{CO}_{2}\left(\mathrm{HCO}_{3}{ }^{-}\right)$added to the water (Appendix A).

\section{G.1. Synthetic Water Constructed from Halite}

Naturally-saline water can contain high concentrations of bicarbonate/carbonate (e.g., sea water) and can contain high concentrations of $\mathrm{Ca}^{2+}$ or $\mathrm{Mg}^{2+}$ ions. Zechstein halite was selected as a suitable halite for the trials, because its molar $\mathrm{Na}: \mathrm{Cl}$ ratio can be correlated to $\mathrm{K}^{+}, \mathrm{Mg}^{2+}$ and $\mathrm{SO}_{4}{ }^{2-}$ concentrations (Figure G1). The halite is not homogenous. Therefore, different saline water batches can be expected to contain different molar ratios for Na:Cl:Mg:K: $\mathrm{SO}_{4}{ }^{2-}$. The feed water $\mathrm{Na}$ and $\mathrm{Cl}$ compositions are provided for Trial Groups E144 (Table 1) and E146 (Figure E5).
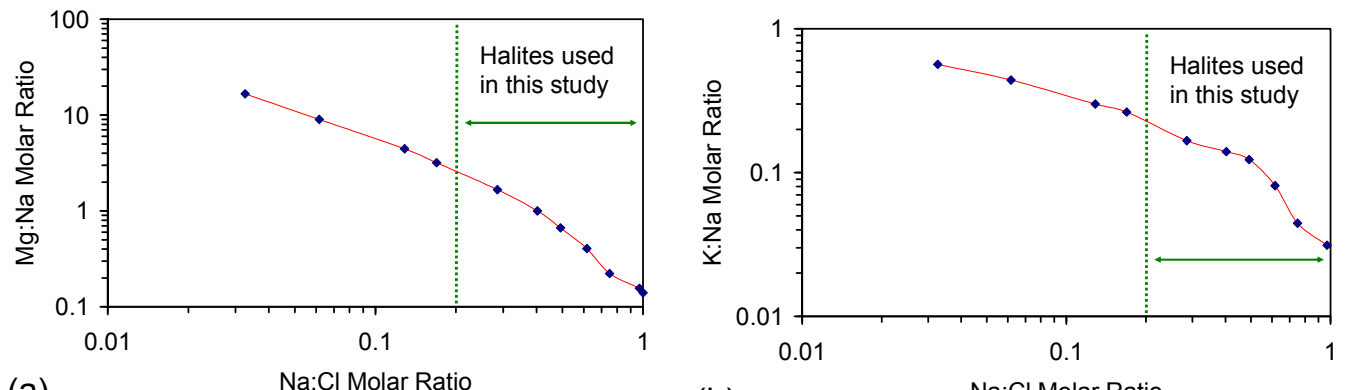

(a)

(b)

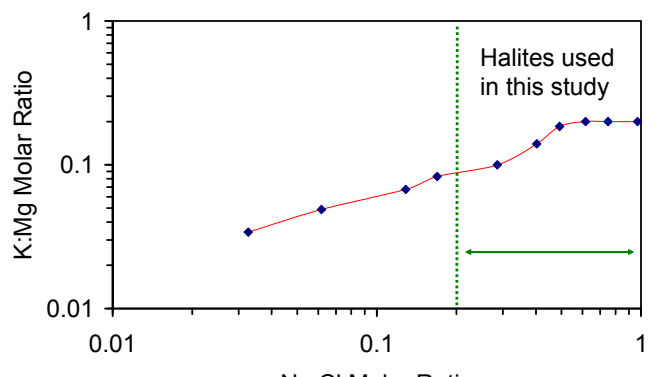

(c)

$\mathrm{Na}: \mathrm{Cl}$ Molar Ratio

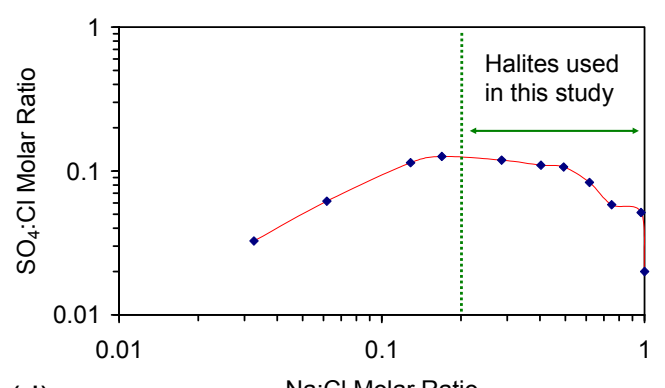

(d)

Figure G1. Relationship between $\mathrm{Na}: \mathrm{Cl}$ molar ratios and $\mathrm{Mg}: \mathrm{Na}$ molar ratios in Zechstein halite. Raw data source: [29]. (a) Na:Cl molar ratio vs. Mg:Na Molar Ratio; (b) Na:Cl molar ratio vs. K:Na Molar

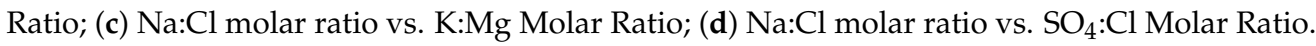




\section{G.2. Interaction of Other Cations and Anions with ZVI}

Detailed ion analyses [1,2] have established that the ZVI will remove (during the desalination process) one or more of: nitrate, chloride, fluoride, sulphate, phosphate, As, B, Ba, Ca, Cd, Co, Cu, Fe, $\mathrm{Mg}, \mathrm{Mn}, \mathrm{Na}, \mathrm{Ni}, \mathrm{P}, \mathrm{S}, \mathrm{Si}, \mathrm{Sr}, \mathrm{Zn}$; while the water is in the reaction environment. The removed anions will either be transformed from one form to another (e.g., nitrate $[26,70,71]$ ), or will be adsorbed in LDH products, or will be precipitated as a (oxy)hydroxide, oxide or carbonate species [63,64].

The most widely-used ratio indicator for irrigation water quality is the sodium adsorption ratio (SAR) [142]. It is calculated as [143]:

$$
\begin{gathered}
\mathrm{SAR}=\mathrm{Na}^{+} /\left(\left(0.5\left(\mathrm{Ca}^{2+}+\mathrm{Mg}^{2+}\right)\right)^{0.5}\right) \text { when cation concentrations are in meq } \cdot \mathrm{L}^{-1} \\
\mathrm{SAR}=\mathrm{Na}^{+} /\left(\left(\mathrm{Ca}^{2+}+\mathrm{Mg}^{2+}\right)^{0.5}\right) \text { when cation concentrations are in mmol } \cdot \mathrm{L}^{-1} \\
\mathrm{SAR}_{\mathrm{adj}}=\mathrm{Na}^{+} /\left(0.5\left(\mathrm{Ca}_{\mathrm{eq}}^{2+}+\mathrm{Mg}^{2+}\right)^{0.5}\right) \text { when units are meq. } \mathrm{L}^{-1} \\
\mathrm{SAR}_{\mathrm{adj}}=\mathrm{Na}^{+} /\left(\left(\mathrm{Ca}_{\mathrm{eq}}^{2+}+\mathrm{Mg}^{2+}\right)^{0.5}\right) \text { when units are mmol } \mathrm{L}^{-1} \\
\mathrm{Ca}_{\mathrm{eq}}^{2+}=X\left(P_{\mathrm{CO} 2}\right)^{1 / 3}=2 \times 10^{\mathrm{Log}(X)} \times\left(P_{\mathrm{CO} 2}\right)^{1 / 3} \\
I_{\mathrm{S}}=(1.3477 \mathrm{C} C+0.5355) / 1000 \\
\log (\mathrm{X})=(1 / 3)\left[4.6629+0.6103 \log (\mathrm{Is})+0.844[\log (\mathrm{Is})] 2+2 \log \left(\mathrm{Ca}^{2+} / 2 \mathrm{HCO}_{3}^{-}\right)\right]
\end{gathered}
$$

$I_{S}=$ ionic strength; $S C=\mathrm{Na}+\mathrm{Ca}+\mathrm{Mg}\left(\mathrm{meq} \cdot \mathrm{L}^{-1}\right) ;\left(P_{\mathrm{CO} 2}\right)=$ partial pressure of $\mathrm{CO}_{2} ;\left(P_{\mathrm{CO} 2}\right)=$ partial pressure of $\mathrm{CO}_{2}=$ pressure times concentration of $\mathrm{CO}_{2} ;\left(P_{\mathrm{CO} 2}\right)_{\text {atmosphere }}=$ varies with time and location but approximates to 0.0004 atmospheres, i.e., $\left(\left(P_{\mathrm{CO} 2}\right)^{1 / 3}\right)=0.0737 . \mathrm{CO}_{2}$ in the atmosphere is in equilibrium with the concentration of dissolved $\mathrm{CO}_{2}$ in the water where $\mathrm{CO}_{2}(\mathrm{aq})=\mathrm{CO}_{2}(\mathrm{~g})+\mathrm{H}_{2} \mathrm{O}$ (l), and the equilibrium constant, $K_{H}=\left(P_{\mathrm{CO} 2}\right) /\left[\mathrm{CO}_{2}(\mathrm{aq})\right]$. The $\left(\mathrm{Ca}^{2+} / 2 \mathrm{HCO}_{3}{ }^{-}\right)$ratio is expressed in $\mathrm{mmol} \cdot \mathrm{L}^{-1} ;\left(P_{\mathrm{CO} 2}\right)^{1 / 3}$ approximates to 0.17758 for soil when $\left(P_{\mathrm{CO} 2}\right)=0.0007$ atmospheres. In all cases, a reduction of $\mathrm{Na}^{+}$results in a reduction in SAR. Decreases in the ratio $\left(\mathrm{Ca}^{2+} / 2 \mathrm{HCO}_{3}{ }^{-}\right)$resulting from increased bicarbonate concentration result in a decrease in $\mathrm{Ca}_{\mathrm{eq}}{ }^{2+}$ and may result in an increase in SAR $_{\text {adj }}$.

One of the side effects of ZVI desalination is that the differential removal of $\mathrm{aNa}+\mathrm{bCa}+\mathrm{cMg}$ can result in a reduction of $\mathrm{Na}^{+}$and an increase in SAR [2].

\section{G.3. Desalination of More Complex Water}

Trials CSD and E143 (Appendix A) considered desalination of water dominated by $\left(\mathrm{Na}^{+}, \mathrm{Cl}^{-}\right)$and $\left(\mathrm{Na}^{+}, \mathrm{Cl}^{-}, \mathrm{HCO}_{3}^{-}\right)$. Trials E143, E146 considered the desalination of water dominated by $\left(\mathrm{Na}^{+}, \mathrm{K}^{+}\right.$, $\left.\mathrm{Mg}^{2+}, \mathrm{SO}_{4}{ }^{2-}, \mathrm{Cl}^{-}\right)$and $\left(\mathrm{Na}^{+}, \mathrm{K}^{+}, \mathrm{Mg}^{2+}, \mathrm{SO}_{4}{ }^{2-}, \mathrm{Cl}^{-}, \mathrm{HCO}_{3}{ }^{-}\right)$. Desalination associated with $\mathrm{Ca}-\mathrm{rich}$ water has been documented in reference [2].

Desalination of complex water containing hydrogen sulphide will result in the formation of iron sulphides in the ZVI cartridge (Figure 2). This will require periodic regeneration of the ZVI within the ZVI cartridge by air (e.g., Figure G2) [2].

Ultra-hypersaline and hypersaline (50-300 g. $\left.\mathrm{L}^{-1}\right)$ flowback water associated with shale gas and shale oil and saline mine water can potentially be treated using this approach [1]. The interaction of sulphates and other cations and anions with Fe in saline acid mine water with a high TDS has not been assessed at this time. 


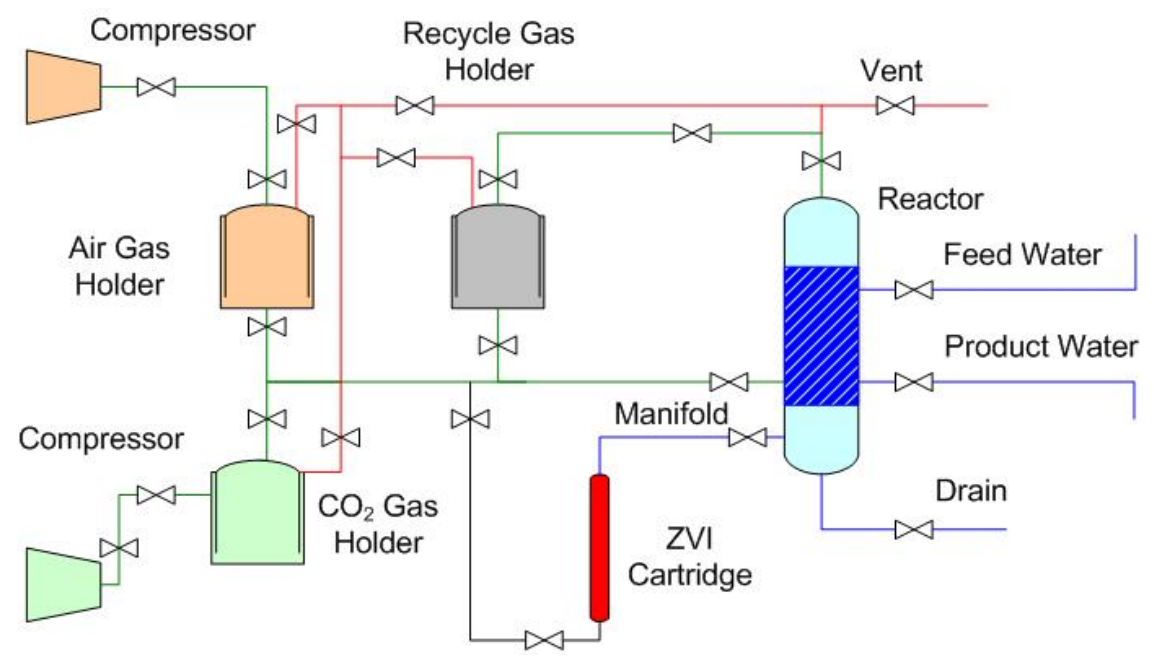

Figure G2. Schematic process flow diagram for a gas pressured desalination unit, including a ZVI sulphide regeneration flow line.

\section{Appendix H: Desalination Pathway}

The exact desalination products manufactured by the desalination process (or processes) and the associated reaction routes have not been conclusively elucidated at this time.

Two possibilities have been considered in this study: (i) the $\mathrm{NaCl}$ is transformed from one form to another and is retained in the water following desalination (e.g., Appendix C); (ii) the $\mathrm{NaCl}$ is retained in the ZVI or is retained in entrained ZVI associated precipitates in the water (e.g., Appendix B).

Two other possibilities have been investigated:

1. The $\mathrm{NaCl}$ is removed with the gas when it is bubbled through the water. This has been investigated by passing the product gas through a series of downstream traps. No increases in salinity have been observed in the downstream traps (e.g., [1]).

2. The $\mathrm{NaCl}$ is removed as gaseous components. The product gas composition has been monitored (SRI 8610C thermal conductivity detector (manufactured by SRI Instruments, Torrance, CA, USA)), and only $\mathrm{H}_{2}$ [1], $\mathrm{N}_{2}, \mathrm{CO}_{2}, \mathrm{O}_{2}$ and $\mathrm{H}_{2} \mathrm{O}$ have been identified. Mass balance analyses of the feed gases and product gases have indicated that no additional species are present in the product gas. Consequently, flue gas analyses for chlorinated gaseous products using ECD (electron capture detectors) or DELCD (dry electrolytic conductivity detectors) have not been undertaken.

The first stage in the removal of $\mathrm{Na}^{+}$and $\mathrm{Cl}^{-}$ions may be physisorption (Step 1, Equation (E5)) in the hydration shells of LDH and associated species, e.g., FeOOH [49].

Physisorption implies that Step 1 is reversible and that no special bonding occurs between the ZVI and $\mathrm{NaCl}$ (e.g., the $\mathrm{Na}^{+}$and $\mathrm{Cl}^{-}$ions are trapped within the inter-particle and intra-particle porosity of the ZVI). The second permanent removal Step 2 may include entrapment in the inter-particle and intra-particle porosity, but probably includes one or more of associative adsorption, dissociative adsorption and reaction coupled with adsorption.

\section{H.1. Nature of the Desalination Pathway}

The time incremental desalination rate constants, $k$, were calculated for Trials E1431 to E143v. A plot of $\log (k)$ vs. $1 / T$ (Figure H1) established that the data points for each trial could be fitted with a straight line (i.e., the desalination reaction can be described as a pseudo-first order reaction). The slope of this line is $-E_{a} /(2.303 R)$ [27]. The regression slope has different magnitudes and different directions with different trials. This dataset is consistent with $E_{2}$ oscillating between $E_{2}+\Delta H_{1}<0$ and $E_{2}+\Delta H_{1}$ 
$>0$ (Figure F1b) in different water batches. These observations are consistent with the desalination reaction involving multiple steps (Equation (E5) and Figure F1b).
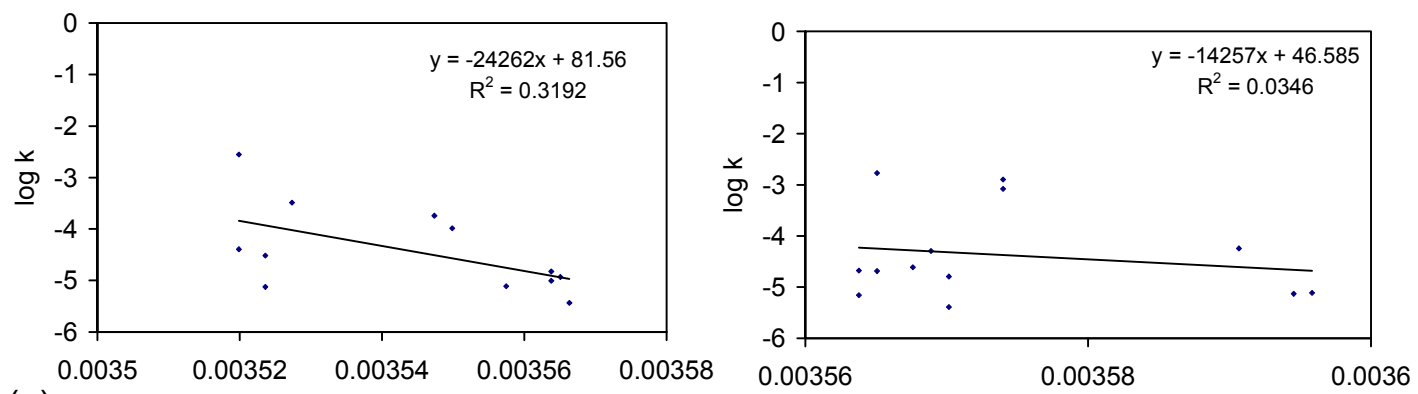

(a)

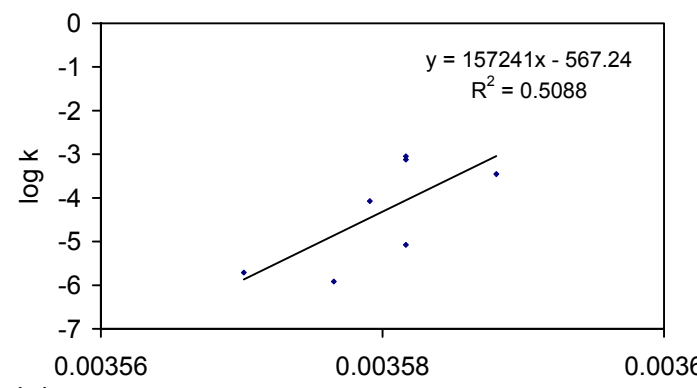

(c)

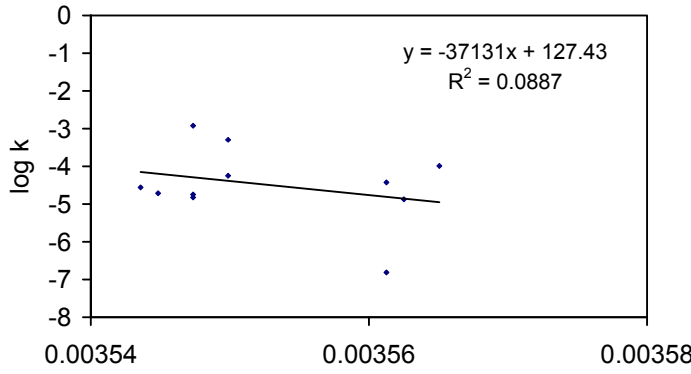

(e)

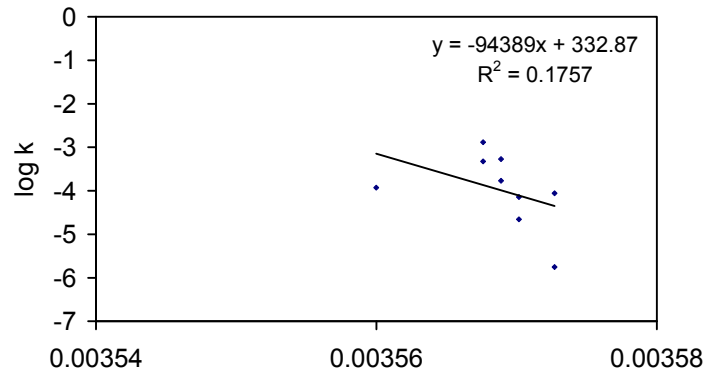

(g)

$1 / T$ (b)

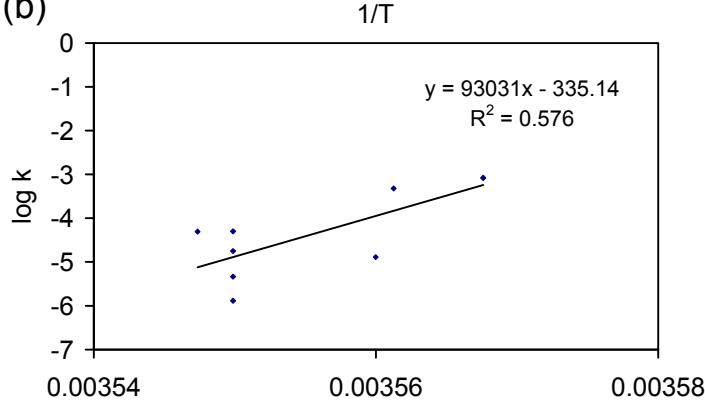

(d)

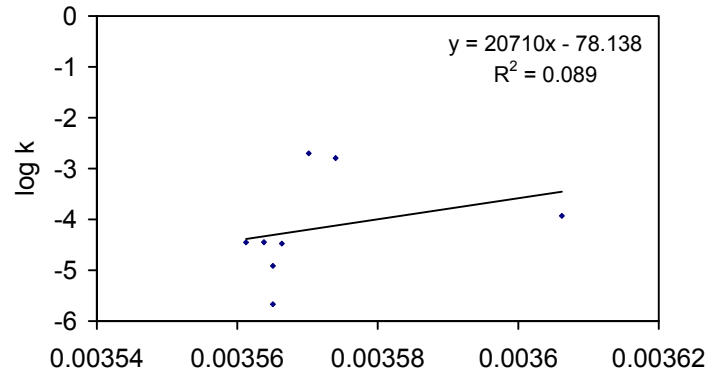

(f)

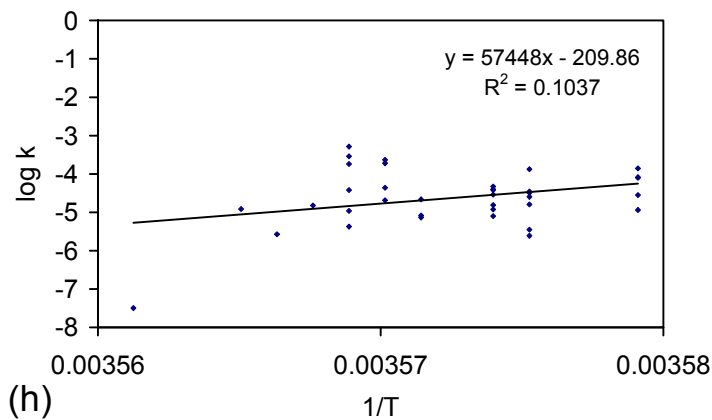

Figure H1. Cont. 

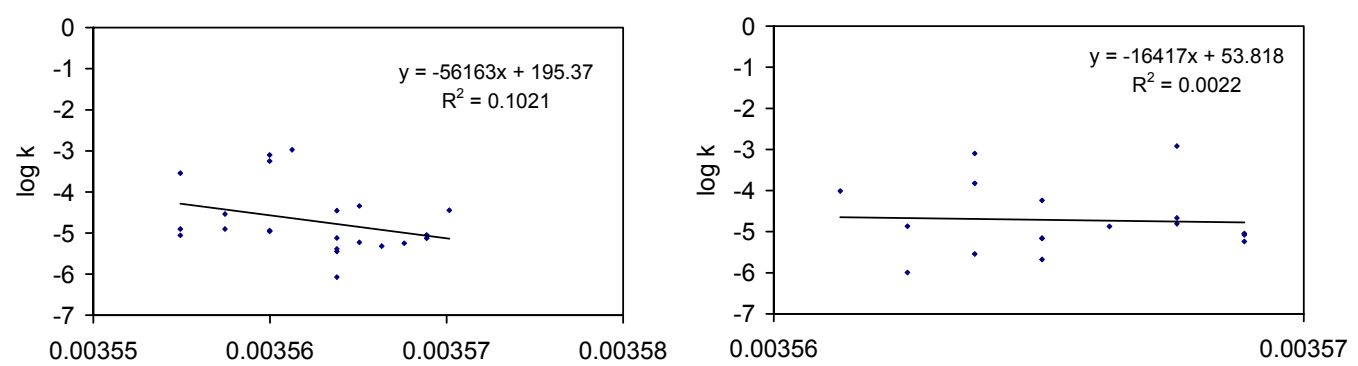

(i)



Figure H1. E143 group trials: (a) E1431; (b) E143m; (c) E143n; (d) E143o; (e) E143p; (f) E143q; (g) E143r; (h) E143s; (i) E143t; (j) E143u; (k) E143v. Further information about these trials is provided in Figure E4.

\section{H.2. Gas Saturation and Gas Pressure Implications}

Equations (E2) and (E3) indicate that the first stage in the desalination process is the manufacture of electrons and protons. Equations (F5) and (F6) establish that this is a complex reaction where the first stage is a reversible redox reaction (Equation (E3)) and the second permanent stage is catalysed by an LDH (Equations (F5) and (F6)) or similar species. The relative permeability of the ZVI to a gas can be approximated as [144]:

$$
\begin{gathered}
C_{V}=d^{2} / 32 \tau \text { Inter }- \text { particle } \\
C_{K}=d / 3 \tau \text { Inter }- \text { particle } \\
C_{F}=\phi / \tau \text { Intra }- \text { Particle }
\end{gathered}
$$

where the appropriate gas permeability constants $\left(k_{p}\right)$ within the ZVI are: Fickian diffusion $\left(C_{F}\right)>$ Knudsen Diffusion $\left(C_{K}\right)>$ viscous flow $\left(C_{V}\right)$.

$\Phi$ (Equation (E9)) is controlled by the pressure wave created by the flowing gas and the pressure within the reactor, which is maintained by the gas (Figure 2). If the rate constant can be represented as:

$$
\left.\operatorname{Ln}\left(\mathrm{NaCl}_{t=0} / \mathrm{NaCl}_{t=\mathrm{n}}\right)=k t=\left(\begin{array}{llll}
\eta k_{n} & a_{s} & P_{w}\left(C_{A Z V I}\right)^{x 1} & d_{\mathrm{ZW}} / n_{t}
\end{array}\right)\right)(t / a)
$$

then $k$ will increase as $\Phi$ increases; where the ZVI column in the ZVI cartridge (with a total thickness of $n_{t}$ ) can be subdivided into $j$ segments, each with a thickness, $d_{Z W}$; the summation is for Segments $1-j ; k_{n}=$ normalized rate constant; $a=$ a pressure related constant, e.g., pressure/atmospheric pressure; $a_{s}=$ ZVI surface area, $\mathrm{m}^{2} / \mathrm{g} ; P_{w}=$ ZVI weight, $\mathrm{g} \cdot \mathrm{L}^{-1} ; \eta=\mathrm{ZVI}$ efficiency factor, where $0 \leqslant \eta \leqslant 1=$ (overall reaction rate)/(reaction rate if the entire surface area is available for reaction); $\left(C_{A Z V I}\right)^{x 1}=$ gas component (e.g., $\mathrm{O}_{2}, \mathrm{~N}_{2}, \mathrm{CO}_{2}$ or related ion species (e.g., $\mathrm{O}_{\mathrm{n}}{ }^{x-}, \mathrm{O}_{\mathrm{x}} \mathrm{H}^{-}, \mathrm{H}_{\mathrm{x}} \mathrm{CO}_{3}^{-}$, etc.)) concentration on the ZVI surface within the thickness increment; $\left(C_{A Z V I}\right)^{x 1}$ decreases with increasing distance from the ZVI-water contact; $x 1$ = reaction order.

\section{Appendix I: Mineralogical Issues}

The discussion and analyses in Appendix E have demonstrated that the key controls on desalination are the formulation of the ZVI and the operation of the reaction environment. The 
discussion in Appendix $\mathrm{B}$ and Appendix $\mathrm{C}$ has assumed that the removal of the $\mathrm{Na}^{+}$and $\mathrm{Cl}^{-}$ions is entirely abiotic. While this is a possible outcome, saline environments are host to a variety of iron-reducing archaea and bacteria. The interaction of biotic and abiotic processes during desalination has not been assessed.

The chemistry of $\mathrm{Fe}_{\mathrm{x}} \mathrm{O}_{\mathrm{y}} \mathrm{H}_{\mathrm{z}}$ species is complex and is incompletely understood (e.g., Appendix B). The Eh and pH regime of the CSD, E143, E144 and E146 trials (Figures E2, E4 and E5) indicates [63] that the entrained equilibrium precipitant (within the water body) will be dominated by $\mathrm{Fe}^{\mathrm{III}}$, but both $\mathrm{Fe}^{\mathrm{II}}$ and $\mathrm{Fe}^{\mathrm{III}}$ species are likely to be present (Figure I1a).

Product water analyses may overestimate the $\mathrm{pH}$ in the ZVI cartridge (as demonstrated by E143k [2]) and will overestimate the Eh of the pore water within the ZVI [71].

If it is assumed (from the preceding discussion) that the desalination reaction occurs in the ZVI, then either continuous monitoring of the Eh in the ZVI bed is required or a suitable Eh correction should be applied to the product water Eh values in order to establish the probable Eh regime within the ZVI cartridge.

A measured regression relationship between Eh in the product water and Eh in the ZVI (in a static diffusion environment (Figure 1)) has been established [71]. This regression relationship [71] is applied here (Figure I1b) in order to establish the probable nature of the active ZVI desalination sites.

Figure I1b indicates that the active surface contains $\mathrm{Fe}^{\mathrm{n}+}$ species. Exposure of this active surface to air results in rapid oxidation and the visible formation of orange-brown $\mathrm{Fe}^{3+}$ oxyhydroxide precipitants on the drying surface.
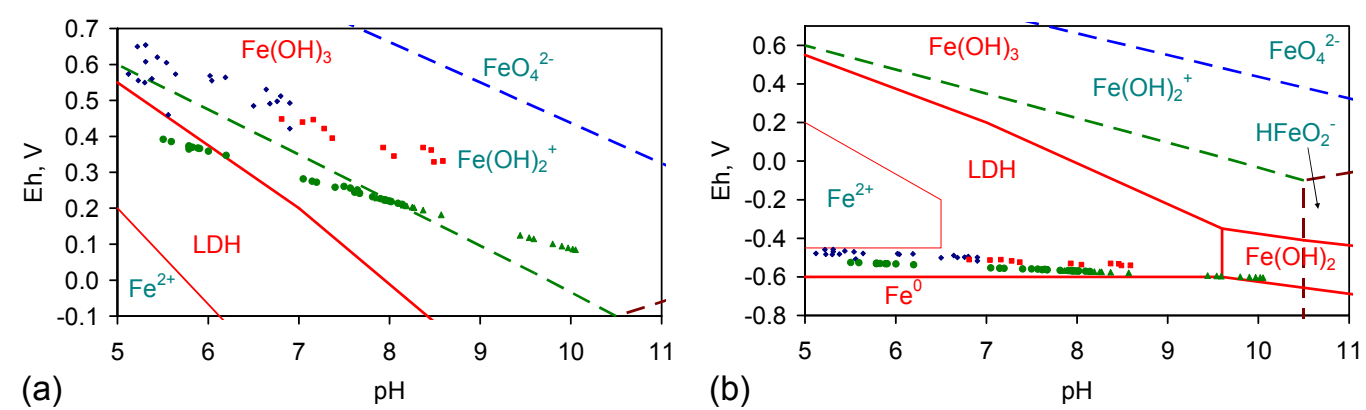

Figure I1. Eh vs. $\mathrm{pH}(\mathbf{a})$ product water; (b) expected Eh vs. $\mathrm{pH}$ inside the ZVI cartridge (Eh in ZVI bed $=0.257 \mathrm{x}-0.6258, \mathrm{x}=$ Eh of product water. Equation source: [71]). $\downarrow=$ Trial Groups CSD, E143, E144 (Appendix A, Figure E2a-c); $\mathbf{~ = ~ T r i a l ~ G r o u p ~ E 1 4 3 ~ ( F i g u r e ~ E 4 ) ; ~} \boldsymbol{\Delta}$ = Trial Group E146 (Figure E2d); $\bullet=$ Trial Group E147 (Figure E5). Red solid lines separate equilibrium Fe species precipitation phases [63]. Dashed lines separate Fe ion species equilibrium stability fields [63]. The layered double hydroxide (LDH) field is defined by the envelope encompassed by: (i) Eh $=0.728-$ $0.1773 \mathrm{pH}-0.0591 \log \left(\mathrm{Fe}^{2+}\right)$ [63]; (ii) $\mathrm{Eh}=-0.44+0.0295 \log \left(\mathrm{Fe}^{2+}\right)$ [63]; (iii) $13.29=2 \mathrm{pH}+\mathrm{Log}$ $\left(\mathrm{Fe}^{2+}\right)$ [63]. Illustrated limits are for $\log \left(\mathrm{Fe}^{2+}\right)=0$ to $\log \left(\mathrm{Fe}^{2+}\right)=-6$ at $25^{\circ} \mathrm{C}$. $\mathrm{Fe}^{2+}$ includes $\mathrm{Fe}(\mathrm{OH})^{+}$ and associated species. Further information about these redox boundaries and how they change with temperature, pressure and ion concentration is provided in [63].

\section{I.1. Desalination Mechanism: Step 1}

The analysis in Figure I1b is consistent with the ZVI reaction surface containing a mixture of $\mathrm{Fe}^{0}$, $\mathrm{Fe}^{\mathrm{I}}, \mathrm{Fe}^{\mathrm{II}}$ and $\mathrm{Fe}^{\mathrm{III}}$ species. If the cross-coupling reaction model is applied to the ZVI surface (e.g., [71]), then it is apparent (Figure I2) that the ZVI reaction surface will take $\mathrm{H}-\mathrm{Cl}$ and $\mathrm{Na}-\mathrm{OH}$ ion adducts within the water and convert them to $\mathrm{NaCl}(\mathrm{aq})$ (see Equation (E1)).

This reaction sequence will allow adsorption and desorption of $\mathrm{Na}^{+}$and $\mathrm{Cl}^{-}$ions from the $\mathrm{ZVI}$ surface. The potential simultaneous operating oscillating cycles are between $\mathrm{Fe}^{\mathrm{I}}$ and $\mathrm{Fe}^{\mathrm{III}}, \mathrm{Fe}^{\mathrm{I}}$ and $\mathrm{Fe}^{\mathrm{II}}$, and $\mathrm{Fe}^{\mathrm{II}}$ and $\mathrm{Fe}^{\mathrm{III}}$ [71]. Each cycle will operate at a different speed and interact with each adjacent 
cycle [71]. The interaction of Step 2 (Equation (E5)) with this cycle controls the rate of desalination and the final equilibrium salinity of the product water. Permanent $\mathrm{Na}^{+}$and $\mathrm{Cl}^{-}$ion removal occurs when this cycle is disrupted.

In chloride rich solutions containing free protons, the $\mathrm{Fe}^{\mathrm{III}}$ sites (Figure I2) will restructure to form complexation sites, which are ideally defined by eight surrounding hydroxyl groups (e.g., $\left.\equiv(\mathrm{OH})_{8}\right)$ [145]. Neighbouring sites are bound by oxo groups (e.g., $\left.\equiv \mathrm{O}\right)$ [145]. The protons migrate towards the oxo groups to create a complex of the form $\equiv(\mathrm{OH})_{8}-\mathrm{Cl}-\mathrm{HO} \equiv[145]$. The generic equation for this type of $\mathrm{Fe}^{\mathrm{III}}$ structure is $\beta-\mathrm{FeOOH} \cdot(\mathrm{HCl})_{\mathrm{n}}[145] \cdot n=0.192$ corresponds to $70 \%$ occupancy in the tunnels within the mineral complex [145]. This process may provide a mechanism (Step 2), which disrupts the general cycle in Figure I2.

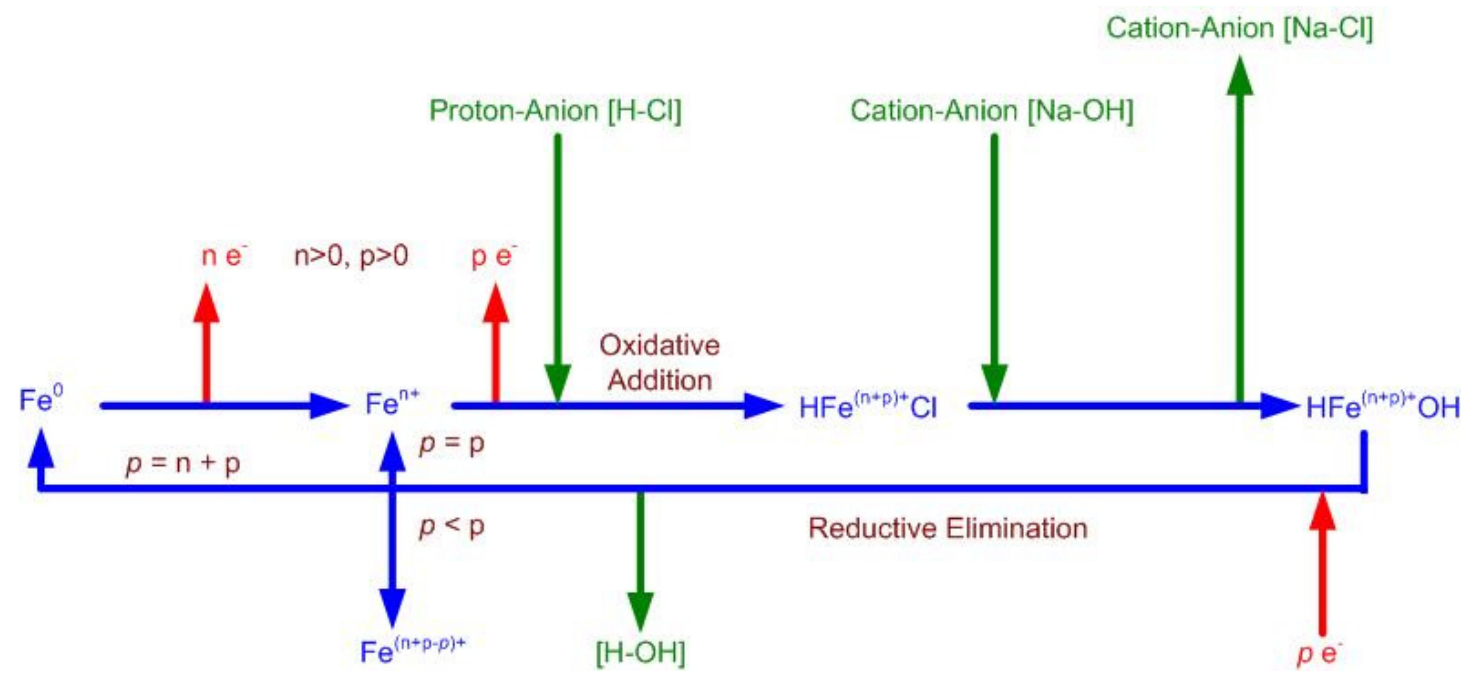

Figure I2. Proposed dominant adsorption-desorption cross-coupling reaction sequence for $\mathrm{Cl}^{-}$ions in the ZVI (Step 1, Equation (E5)). ( $n+p)$ control the Fe valency. Reversal of the proton-anion and cation-anion couplings results in $\mathrm{Na}^{+}$adsorption. When $\mathrm{pe}^{-}>\mathrm{pe}^{-}$, the valency of $\mathrm{Fe}^{\mathrm{n}+}$ will increase on the next cycle (and vice versa). A similar cycle may operate for the removal of $\mathrm{Na}^{+}$ions. This cross-coupling model is consistent with the galvanic model of ZVI remediation, which is described further in $[70,71]$.

\section{I.2. Desalination Mechanism: Amorphous Iron Hydroxides}

Analyses of iron permeable reactive barriers (1-2.5 years following installation) have established that in chloride-rich waters, the iron corrodes to first produce an amorphous (hydrated) iron hydroxide deposit, which gradually transforms (crystallizes) to form crystalline $\beta-\mathrm{FeOOH}$ [146]. The crystalline $\beta$-FeOOH can be expected to have a surface area of $140-330 \mathrm{~m}^{2} \cdot \mathrm{g}^{-1}$ [147]. Absorbance using $\beta-\mathrm{FeOOH}$ follows a pseudo-second order kinetic model, where the selectivity order is $\mathrm{Cl}^{-}>\mathrm{CO}_{3}{ }^{2-}>\mathrm{NO}_{3}{ }^{-}>$ $\mathrm{SO}_{4}{ }^{2-}>\mathrm{H}_{2} \mathrm{PO}_{4}{ }^{2-}$ [147]. Absorbed ion concentrations can exceed $0.45 \mathrm{~g} \cdot \mathrm{g}^{-1}$ [147].

Chlorides have been demonstrated to be preferentially bound to the freshly-formed amorphous (hydrated) iron hydroxide precursors (e.g., Figure I2) during the initial hydrolysis of $\mathrm{Fe}^{3+}$ [148]. This amorphous material can eventually crystallize as akaganeite $[146,148]$, but may (during forced hydrolysis) crystallize as hematite $\left(\alpha-\mathrm{Fe}_{2} \mathrm{O}_{3}\right)$ [149].

\section{I.3. Humic Acids and Microbiota}

Humic acids, when present, will react with both the iron and iron hydroxides [150-156]. No ZVI desalination trials have been undertaken to date on saline water containing high concentrations of humic or carboxylic acids. 
A further complication is the presence of iron reducing bacteria, sulphate reducing and other anoxic bacteria and archaea [157-161]. No ZVI desalination trials have been undertaken to date on saline water containing high concentrations of iron reducing bacteria and other microbiota.

The mineralogy of the ZVI bed during desalination, the relationship between various operational strategies and ZVI mineralogy and the interaction of the ZVI bed with high concentrations of dissolved organic substances and microbiota during desalination are all areas for potential future investigation.

\section{References}

1. Antia, D.D.J. Desalination of groundwater and impoundments using nano-zero valent iron, $\mathrm{Fe}^{0}$. Meteor. Hydrol. Water Manag. 2015, 3, 21-38.

2. Antia, D.D.J. Desalination of water using ZVI, $\mathrm{Fe}^{0}$. Water 2015, 7, 3671-3831. [CrossRef]

3. Fronczyk, J.; Pawluk, K.; Michniak, M. Application of permeable reactive barriers near roads for chloride ions removal. Ann. Warsaw Univ. Life Sci. SGGW Land Reclaim. 2010, 42, 249-259. [CrossRef]

4. Fronczyk, J.; Pawluk, K.; Garbulewski, K. Multilayer PRBs-Effective technology for protection of the groundwater environment in traffic infrastructures. Chem. Eng. Trans. 2012, 28, 67-72.

5. Hwang, Y.; Kim, D.; Shin, H.-S. Inhibition of nitrate reduction by $\mathrm{NaCl}$ adsorption on a nano-zero valent iron surface during concentrate treatment for water reuse. Environ. Technol. 2015, 36, 1178-1187. [CrossRef] [PubMed]

6. Wilkin, R.T.; Puls, R.W.; Sewell, G.W. Long-term performance of permeable reactive barriers using zero valent iron: Geochemical and microbiological effects. Ground Water 2003, 41, 493-503. [CrossRef] [PubMed]

7. Puls, R.W.; Blowes, D.W.; Gilham, R.W. Long-term performance monitoring for a permeable reactive barrier at the US Coast guard support center, Elizabeth City, North Carolina. J. Hazard. Mater. 1999, 68, 109-124. [CrossRef]

8. Wilkin, R.T.; Acree, S.D.; Ross, R.R.; Puls, R.W.; Lee, T.R.; Woods, L.L. Fifteen-year assessment of a permeable reactive barrier for treatment of chromate and trichloroethylene in groundwater. Sci. Total Environ. 2014, 468-469, 186-194. [CrossRef] [PubMed]

9. Liang, L.; Moline, G.R.; Kamolpornwijit, W.; West, O.R. Influence of hydrochemical processes on zero valent iron reactive barrier performance: A field investigation. J. Contam. Hydrol. 2005, 78, 291-312. [CrossRef] [PubMed]

10. Savoie, J.G.; Kent, D.B.; Smith, R.L.; le Blanc, D.R.; Hubble, D.W. Changes in Ground-Water Quality Near Two Granular Iron Permeable Reactive Barriers in a Sand and Gravel Aquifer, Cape Cod, Massachusetts, 1997-2000; Water Resources Investigation Report 03-4309; US Geological Survey: Reston, VA, USA, 2004; p. 77.

11. Wada, Y.; Bierkens, M.F.P. Sustainability of global water use: Past reconstruction and future projections. Environ. Res. Lett. 2014, 9. [CrossRef]

12. Amarasinghe, U.A.; Smakhtin, V. Global Water Demand Projections: Past, Present and Future; Report 156; International Water Management Institute (IWMI): Columbo, Sri Lanka, 2014.

13. Knapp, K.C.; Baerenklau, K.A. Ground water quantity and quality management: Agricultural production and aquifer salinization over long time scales. J. Agric. Resour. Econ. 2006, 31, 616-641.

14. Panta, S.; Flowers, T.; Lane, P.; Doyle, R.; Haros, G.; Shaala, S. Halophyte agriculture: Success stories. Environ. Exp. Bot. 2014, 107, 71-83. [CrossRef]

15. Food and Agricultural Organization (FAO). The State of the World's Land and Water Resources for Food and Agriculture (SOLAW)—Managing Systems at Risk; Food and Agricultural Organization of the United Nations and Earth Scan: Abingdon, UK, 2011.

16. Payen, S.; Basset-Mens, C.; Follain, S.; Grunberger, O.; Marlet, S.; Nunez, M.; Perret, S. Pass the salt please! From a review to a theoretical framework for integrating salinization impacts in food LCA. In Proceedings of the 9th International Conference on Life Cycle Assessment in the Agri-Foods Sector, San Francisco, CA, USA, 8-10 October 2014.

17. Schyns, J.F.; Hamaideh, A.; Hoekstra, A.Y.; Mekonnen, M.M.; Schyns, M. Mitigating the risk of extreme water scarcity and dependency: The case of Jordan. Water 2015, 7, 5705-5730. [CrossRef]

18. Warsinger, D.M.; Mistry, K.H.; Nayar, K.G.; Chung, H.W.; Lienhard, V.J.H. Entropy generation of desalination powered by varied temperature waste heat. Entropy 2015, 17, 7530-7566. [CrossRef] 
19. Eshoul, N.M.; Agnew, B.; Al-Weshahi, M.A.; Atab, M.S. Energy analysis of a two pass reverse osmosis (RO) desalination unit with and without an energy recovery turbine (ERT) and pressure exchanger (PX). Energies 2015, 8, 6910-6925. [CrossRef]

20. Al Hashemi, R.; Zarreen, S.; Al Raisi, A.; Al Marzooqi, F.A.; Hasan, S.W. A review of desalination trends in Gulf Cooperation council countries. Int. Interdiscip. J. Sci. Res. 2014, 1, 72-96.

21. Sorour, M.; Hani, H.A.; Shaalan, H.F.; Al-Bazedi, G.A. Preliminary techno-economics assessment of developed desalination/salt recovery facility based on membrane and thermal techniques. Desalin. Water Treat. 2014. [CrossRef]

22. Venkatesan, R. Comparison between LTTD and RO process of sea-water desalination: An integrated economic, environmental and ecological framework. Curr. Sci. 2014, 106, 378-386.

23. Hofges, A.; Hansen, K.; McLeod, D. The economics of bulk water transport in Southern California. Resources 2014, 3, 703-720.

24. Kjellsson, J.B.; Webber, M.E. The energy-water nexus: Spatially resolved analysis of the potential for desalinating brackish groundwater by use of solar energy. Resources 2015, 4, 476-489. [CrossRef]

25. Chang, H.; Chang, C.-L.; Hung, C.-Y.; Chen, T.-W.; Ho, C.-D. Optimization study of small scale solar membrane distillation desalination systems (s-SMDDS). Int. J. Environ. Res. Public Health 2014, 11, 12064-12087. [CrossRef] [PubMed]

26. Antia, D.D.J. Sustainable zero-valent metal (ZVM) water treatment associated with diffusion, infiltration, abstraction and recirculation. Sustainability 2010, 2, 2988-3073. [CrossRef]

27. Ebbing, D.D.; Gammon, S.D. General Chemistry, 6th ed.; Houghton Mifflin Co.: Boston, MA, USA, 1999.

28. British Standards Institution. Specification for Salt for Spreading on Highways for Winter Maintenance; BS 3247:2011; British Standards Institution: London, UK, 2013.

29. Garcia-Veigas, J.; Cendon, D.I.; Pueyo, J.J.; Peryt, T.D. Zechstein saline brines in Poland, evidence of overturned anoxic ocean during the Late Permian mass extinction event. Chem. Geol. 2011, 290, 189-201. [CrossRef]

30. Dalard, F.; Gourbeyre, Y.; Degrigny, C. Chloride removal from archeological cast iron by pulsating current. Stud. Conserv. 2002, 47, 117-121. [CrossRef]

31. Radkova, L.; Fojtkova, P.; Kozakova, Z.; Krcma, F.; Sazavska, V.; Kujawa, A. Sample temperature during corrosion removal by low pressure low temperature hydrogen RF plasma. Romanian Rep. Phys. 2015, 67, 586-599.

32. Reguer, S.; Dillmann, P.; Mirambet, F. Buried iron archeological artefacts: Corrosion mechanisms related to the presence of $\mathrm{Cl}^{-}$containing phases. Corros. Sci. 2007, 49, 2726-2744. [CrossRef]

33. Reguer, S.; Neff, D.; Remazeilles, C.; Guilminot, E.; Nicot, F.; Pele, C.; Meguelati, M.; Mirambet, F.; Dillmann, P.; Refait, P.; et al. Desalinisation of iron archaeological artifacts: Understanding of chlorine removal mechanisms of the corrosion layers supported by characterization techniques. Innov. Investig. Metal Artifacts 2007, 2, 60-68.

34. Rimmer, M.; Wang, Q. Assessing the effects of alkaline desalination treatments for archaeological iron using scanning electron microscopy. Br. Mus. Tech. Res. Bull. 2010, 4, 79-86.

35. Rimmer, M.; Watkinson, D.; Wang, Q. The efficiency of chloride extraction from archaeological objects using deoxygenated alkaline solutions. Stud. Conserv. 2012, 57, 29-41. [CrossRef]

36. Bayle, M.; de Vivies, P.; Memet, J-B.; Foy, E.; Dillmann, P.; Neff, D. Corrosion product transformations in alkaline baths under pressure and high temperature: The sub-critical stabilization of marine iron artifacts stored under atmospheric conditions. Mater. Corros. 2015.

37. Asenath-Smith, E.; Estroff, L.A. Role of akaganeite $(\beta-\mathrm{FeOOH})$ in the growth of hematite $\left(\alpha-\mathrm{Fe}_{2} \mathrm{O}_{3}\right)$ in an inorganic silica hydrogel. Cryst. Growth Des. 2015, 15, 3388-3398. [CrossRef]

38. Tadic, M.; Milosevic, I.; Kraji, S.; Saboungi, M-L.; Motte, L. Ferromagnetic behaviour and exchange bias effect in akaganeite nanorods. Appl. Phys. Lett. 2015, 116. [CrossRef]

39. Remazeilles, C.; Refait, P.H. On the formation of $\beta-\mathrm{FeOOH}$ (akaganeite) in chloride containing environments. Corros. Sci. 2007, 49, 844-857. [CrossRef]

40. Mackay, A.L. Beta-ferric oxyhydroxide. Mineral. Mag. 1960, 32, 545-557. [CrossRef]

41. Mackay, A.L. Beta-ferric oxyhydroxide-Akaganeite. Mineral. Mag. 1962, 33, 270-280. [CrossRef]

42. Bottero, J.-Y.; Manceau, A.; Villieras, F.; Tchoubar, D. Structure and mechanisms of formation of $\mathrm{FeOOH}(\mathrm{Cl})$ polymer. Langmuir 1994, 10, 316-319. [CrossRef] 
43. Dante, S.; Hou, Z.; Risbud, S.; Stroeve, P. Nucleation of iron oxy-hydroxide nanoparticles by layer-by-layer polyionic assemblies. Langmuir 1999, 15, 2176-2182. [CrossRef]

44. Hu, Y.; Chen, K. Crystal splitting in the growth of $\beta-\mathrm{FeO}(\mathrm{OH})$. J. Cryst. Growth 2007, 308, 185-188. [CrossRef]

45. Song, H.-J.; Liu, L.; Jia, X.-H. Synthesis of multiwalled carbon nanotubes / $\beta$-FeOOH nanocomposites with high adsorption capacity. J. Nanopart. Res. 2012, 14. [CrossRef]

46. Parameshwari, R.; Priyadarshini, P.; Chandrasekaran, G. Optimization, structural, spectroscopic and magnetic studies on stable akaganeite nanoparticles via co-precipitation method. Am. J. Mater. Sci. 2011, 1, 18-25.

47. Konishi, H.; Yamashita, M.; Uchida, H.; Mizuki, J. Characterization of rust layer formed on Fe, Fe-Ni and $\mathrm{Fe}-\mathrm{Cr}$ alloys exposed to $\mathrm{Cl}^{-}$rich environment by $\mathrm{Cl}$ and $\mathrm{Fe} \mathrm{K}-$ edge XANES Measurements. Mater. Trans. 2005, 46, 329-336. [CrossRef]

48. Post, J.E.; Heany, P.J.; von Dreele, R.B.; Hanson, J.C. Neutron and temperature resolved synchrotron X-ray powder diffraction study of akaganeite. Am. Mineral. 2003, 88, 782-788. [CrossRef]

49. Yue, J.; Jiang, X.; Yu, A. Experimental and theoretical study on the $\beta-F e O O H$ nanorods: Growth and conversion. J. Nanopart. Res. 2011, 13, 3961-3974. [CrossRef]

50. Xu, Z.; Liang, J.; Zhou, L. Template-Free hydrothermal synthesis of $\beta$-FeOOH nanorods and their catalytic activity in the degradation of methyl orange by a photo-Fenton-like process. Open J. Inorg. Non Met. Mater. 2013, 3, 58-65. [CrossRef]

51. Garcia, K.E.; Barrero, C.A.; Morales, A.L.; Greneche, J.M. Characterization of akaganeite synthesed in the presence of $\mathrm{Al}^{3+}, \mathrm{Cr}^{3+}$ and $\mathrm{Cu}^{2+}$ ions and urea. Mater. Chem. Phys. 2008, 112, 120-126. [CrossRef]

52. Ishikawa, T.; Katoh, R.; Yasukawa, A.; Kandori, K.; Nakayama, T.; Yuse, F. Influence of metals on the formation of $\beta$-FeOOH particles. Corros. Sci. 2001, 43, 1727-1738. [CrossRef]

53. Kyzas, G.; Peleka, E.N.; Deliyanni, E.A. Nanocrystalline akaganeite as adsorbent for surfactant removal from aqueous solutions. Materials 2013, 6, 184-197. [CrossRef]

54. Remazeilles, C.; Refait, P. Formation, fast oxidation and thermodynamic data of Fe(II) hydroxychlorides. Corros. Sci. 2008, 50, 856-864. [CrossRef]

55. Refait, P.; Genin, J.M.R. The mechanism of oxidation of ferrous hydroxychloride beta- $\mathrm{Fe}_{2}(\mathrm{OH})_{3} \mathrm{Cl}$ in chloride containing aqueous solution: The formation of beta-FeOOH akaganeite, an X-ray diffraction, Mossbauer spectroscopy and electrochemical study. Corros. Sci. 1997, 39, 539-553. [CrossRef]

56. Refait, P.; Drissi, S.H.; Pytkiewicz, J.; Genin, J.M.R. The anodic species competition in iron aqueous corrosion: Role of various green rust compounds. Corros. Sci. 1997, 39, 1699-1710. [CrossRef]

57. Refait, P.; Abdelmoula, M.; Genin, J.M.R. Mechanisms of formation and structure of green rust one in aqueous corrosion of iron in the presence of chloride ions. Corros. Sci. 1998, 40, 1547-1560. [CrossRef]

58. Al-Moubaraki, A.H.; Al-Judaibi, A.; Asiri, M. Corrosion of C-steel in the Red Sea: Effect of immersion time and inhibitor concentration. Int. J. Electrochem. Sci. 2015, 10, 4252-4278.

59. Ruby, C.; Aissa, R.; Gehin, A.; Cortot, J.; Adelmoula, M.; Genin, J.M.R. Green rusts synthesis by coprecipitation of $\mathrm{Fe}^{\mathrm{II}}-\mathrm{Fe}^{\mathrm{III}}$ ions and mass balance diagram. C. R. Geosci. 2006, 338, 420-432. [CrossRef]

60. Taylor, R.M. 1984 Influence of chloride on the formation of iron oxides from Fe(II) chloride. I. Effect of $[\mathrm{Cl}] /[\mathrm{Fe}]$ on the formation of magnetite. Clays Clay Miner. 1984, 32, 167-174. [CrossRef]

61. Refait, P.; Genin, J.M.R. The transformation of chloride containing green rust one into sulphated green rust two by oxidation in mixed $\mathrm{Cl}^{-}$and $\mathrm{SO}_{4}{ }^{2-}$ aqueous media. Corros. Sci. 1994, 36, 55-65. [CrossRef]

62. Ockermann, L.T.; Schreyer, J.M. Preparation of sodium ferrate. J. Am. Chem. Soc. 1951, 73, 5478. [CrossRef]

63. Pourbaix, M. Atlas of Electrochemical Equilibria in Aqueous Solutions, 1st ed.; NACE International: Cebelcor, Houston, TX, USA, 1974.

64. Nesic, S. Key issues related to the internal corrosion of oil and gas pipelines-A review. Corros. Sci. 2007, 49, 4308-4338. [CrossRef]

65. Perez, F.R.; Barrero, C.A.; Walker, A.R.H.; Garcia, K.E.; Nomura, K. Effects of chloride concentration, immersion time and steel composition on the spinel phase formation. Mater. Chem. Phys. 2009, 117, 214-223. [CrossRef]

66. Ning, J.; Zheng, Y.; Young, D.; Brown, B.; Nesic, S. A Thermodynamic study of hydrogen sulphide corrosion of mild steel. In Proceedings of the NACE Corrosion 2013 Conference, Orlando, FL, USA, 17-21 March 2013; p. 2462. 
67. Rahmanto, W.H.; Gumawan, R.N. Corrosion rate of copper and iron in seawater based on resistance measurement. J. Coast. Dev. 2002, 5, 67-74.

68. Sherif, E.-S.S.; Abdo, H.S.; Almajid, A.A. Corrosion behavior of cast iron in freely aerated stagnant Arabian Gulf seawater. Materials 2015, 8, 2127-2138. [CrossRef]

69. Zakowski, K.; Narozony, M.; Szocinski, M.; Darowicki, K. Influence of water salinity on corrosion risk-the case of the southern Baltic Sea coast. Environ. Monit. Assess. 2014, 186, 4871-4879. [CrossRef] [PubMed]

70. Antia, D.D.J. Groundwater water remediation by static diffusion using nano-zero valent metals $[\mathrm{ZVM}]\left(\mathrm{Fe}^{0}\right.$, $\left.\mathrm{Cu}^{0}, \mathrm{Al}^{0}\right), n-\mathrm{FeH}^{n+}, n-\mathrm{Fe}(\mathrm{OH})_{x}, n-\mathrm{FeOOH}, n-\mathrm{Fe}-\left[\mathrm{O}_{x} \mathrm{H}_{y}\right]^{(n+/-)}$. In Nanomaterials for Environmental Protection, 1st ed.; Kharisov, B.I., Kharissova, O.V., Dias, H.V.R., Eds.; Wiley Inc.: Hoboken, NJ, USA, 2014; Chapter 1; pp. 3-25.

71. Antia, D.D.J. Water remediation-Water remediation using nano-zero-valent metals (n-ZVM). In CRC Concise Encyclopedia of Nanotechnology, 1st ed.; Kharisov, B.I., Kharissova, O.V., Ortiz-Mendez, U., Eds.; CRC Press, Taylor \& Francis Group: Boca Raton, FL, USA, 2016; Chapter 84; pp. 1103-1120.

72. Rustad, J.R.; Felmy, A.R.; Hay, B.P. Molecular statics calculations for iron oxide and oxyhydroxide minerals: Towards a flexible model of the reactive mineral-water interface. Geochim. Cosmochim. Acta 1996, 60, 1553-1562. [CrossRef]

73. Hiemstra, T.; van Riemsdijk, W.H. Adsorption and surface oxidation of Fe(II) on metal (hydr)oxides. Geochim. Cosmochim. Acta 2007, 71, 5913-5933. [CrossRef]

74. Ghose, S.K.; Waychunas, G.A.; Trainor, T.P.; Eng, P.J. Hydrated goethite $(\alpha-\mathrm{FeOOH})(100)$ interface structure: Ordered water and surface functional groups. Geochim. Cosmochim. Acta 2010, 74, 1943-1953. [CrossRef]

75. Majzian, J.; Mazeina, L.; Navrotsky, A. Enthalpy of water adsorption and surface enthalpy of lepidocrocite ( $\gamma$-FeOOH). Geochim. Cosmochim. Acta 2007, 71, 615-623. [CrossRef]

76. Kozin, P.A.; Boily, J.-F. Mineral surface charge development in mixed electrolyte solutions. J. Colloid Interface Sci. 2014, 418, 256-253. [CrossRef] [PubMed]

77. Sten, P.; Olin, M.; Lehikoinen, J. Surface Complexation on Iron Oxides with Reference to the Oxide Films Formed on Material Surfaces in Nuclear Power Plants; VTT Tiedotteita-Meddelanden-Research Notes 2055; VTT Technical Research Centre of Finland: Espoo, Finland, 2000.

78. Rives, V. Layered Double Hydroxides: Present and Future; Nova Science Publication: New York, NY, USA, 2001.

79. Waseda, Y.; Suzuki, S. Characterization of Corrosion Products on Steel Surfaces; Springer: Berlin, Germany, 2006.

80. Krivovichev, S.V. Structural Crystallography of Inorganic Oxysalts; IUCr Monographs on Crystallography; Oxford University Press: Oxford, UK, 2009.

81. Antia, D.D.J. 2008 Oil polymerisation and fluid expulsion from low temperature, low maturity, over pressured sediments. J. Petrol. Geol. 2008, 31, 263-282. [CrossRef]

82. Wang, C.; Zhao, H.; Wang, H.; Liu, L.; Xiao, C.; Ma, D. The effects of ionic additives on the aqueous phase Fischer-Tropsch synthesis with ruthenium nanoparticle catalyst. Catal. Today 2012, 183, 143-153. [CrossRef]

83. Sander, S.P.; Friedl, R.R.; Abbatt, J.P.D.; Barker, J.R.; Burkholder, J.B.; Golden, D.M.; Kolb, C.E.; Kurylo, M.J.; Mortgat, G.K.; Wine, P.H.; et al. Chemical Kinetics and Photochemical Data for Use in Atmospheric Studies; Evaluation Number 17, JPL (Jet Propulsion Laboratory) Publication 10-6; National Aeronautic and Space Administration (NASA): Pasadena, CA, USA, 2011.

84. Maric, D.; Burrows, J.P.; Meller, R.; Moortgat, G.K. A study of the UV-visible absorption spectrum of molecular chlorine. J. Photochem. Photobiol. A Chem. 1993, 70, 205-214. [CrossRef]

85. Catoire, V.; Lesclaux, R.; Lightfoot, P.D.; Rayez, M.T. Kinetic study of the reactions of $\mathrm{CH}_{2} \mathrm{ClO}_{2}$ with itself and with $\mathrm{HO}_{2}$, and theoretical study of the reactions of $\mathrm{CH}_{2} \mathrm{ClO}$, between 251 and $600 \mathrm{~K}$. J. Hys. Chem. 1994, 98, 2889-2898. [CrossRef]

86. Pye, K. An occurrence of akaganeite $(\beta-\mathrm{FeOOH} \cdot \mathrm{Cl})$ in Recent oxidized carbonate concretions, Norfolk, England. Min. Mag. 1988, 52, 125-126. [CrossRef]

87. Varnado, C.D.; Rosen, E.L.; Collins, M.S.; Lynch, V.M.; Bielawski, C.W. Synthesis and study of olephin metathesis catalysts supported by redox switchable diaminocarbene[3]ferocenophanes. Dalton Trans. 2013, 42, 13251-13264. [CrossRef] [PubMed]

88. Muraoka, M.; Gillett, S.L.; Bell, T.W. Redox-Switchable Materials. US Patent application US2005/0227071 A1, 28 December 2001.

89. Arumugam, K.; Varnado, C.D.; Sproules, S.; Lynch, V.M.; Bielawski, C.W. Redox-switchable ring closing metathesis: Catalyst design, synthesis and study. Chemistry 2013, 19, 10866-10875. [CrossRef] [PubMed] 
90. Lide, D.R. CRC Handbook of Chemistry and Physics, 89th ed.; CRC Press, Taylor and Francis Group: Boca Raton, FL, USA, 2008.

91. Antia, D.D.J. Modification of aquifer pore water by static diffusion using nano-zero-valent metals. Water 2011, 3, 79-112. [CrossRef]

92. Gavaskar, A.; Tatar, L.; Condit, W. Cost and Performance Report: Nanoscale Zero-Valent Iron Technologies for Source Remediation; Contract Report CR-05-007-ENV; NAVFAC Naval Facilities Engineering Command, Engineering Service Center: Port Hueneme, CA, USA, 2005; p. 44.

93. Henderson, A.D.; Desmond, A.H. Long-term performance of zero valent iron permeable reactive barriers: A critical review. Environ. Sci. Eng. 2007, 24, 401-423. [CrossRef]

94. Obiri-Nyarko, F.; Grajales-Mesa, S.J.; Malina, G. An overview of permeable reactive barriers for in situ sustainable groundwater remediation. Chemosphere 2014, 111, 243-259. [CrossRef] [PubMed]

95. Fu, F.; Dionysiou, D.D.; Liu, H. The use of zero valent iron for groundwater remediation and wastewater treatment: A review. J. Hazard. Mater. 2014, 267, 194-205. [CrossRef] [PubMed]

96. Guan, X.; Sun, Y.; Qin, H.; Li, J.; Lo, I.M.C.; He, D.; Dong, H. The limitations of applying zero valent iron technology in contaminants sequestration and the corresponding countermeasures: The development in zero-valent iron technology in the last two decades (1994-2014). Water Res. 2015, 75, 224-248. [CrossRef] [PubMed]

97. Noubactep, C. Metallic iron for environmental remediation: A review of reviews. Water Res. 2016, 85, 114-123. [CrossRef] [PubMed]

98. Stefaniuk, M.; Oleszczuk, P.; Ok, Y.S. Review on nano zerovalent iron (nZVI): From synthesis to environmental applications. Chem. Eng. J. 2016, 287, 618-632. [CrossRef]

99. Lai, K.C.K. Field evaluation of the performance and heterogeneity of a zero valent iron based permeable reactive barrier for groundwater remediation. HKIE Trans. Hong Kong Inst. Eng. 2007, 14, 2-12.

100. Cundy, A.B.; Hopkinson, L.; Whitby, R.L.D. Use of iron-based technologies in contaminated land and groundwater remediation: A review. Sci. Total Environ. 2008, 400, 42-51. [CrossRef] [PubMed]

101. Kobbe-Dama, N.; Noubactep, C.; Tchatchueng, J.-B. Metallic iron for water treatment: Prevailing paradigm hinders progress. Fresenius Environ. Bull. 2013, 22, 2953-2957.

102. Muchitsch, N.; van Nooten, T.; Bastiaens, L.; Kjeldsen, P. Integrated evaluation of the performance of a more than seven year old permeable reactive barrier at a site contaminated with chlorinated aliphatic hydrocarbons (CAHs). J. Contam. Hydrol. 2011, 126, 258-270. [CrossRef] [PubMed]

103. Gatcha-Bandjun, N.; Noubactep, C.; Benoit, L.M. Water treatment with $\mathrm{Fe}^{0} / \mathrm{H}_{2} \mathrm{O}$ systems: Learning from internal electrolysis. Fresenius Environ. Bull. 2014, 23, 2663-2669.

104. Tsinde, R.T.; Phukan, M.; Nassi, A.; Noubactep, C.; Ruppert, H. Validating the efficiency of the MB discoloration method for the characterization of $\mathrm{Fe}^{0} / \mathrm{H}_{2} \mathrm{O}$ systems using accelerated corrosion by chloride ions. Chem. Eng. J. 2015, 279, 353-362. [CrossRef]

105. Mackenzie, P.D.; Horney, D.P.; Sivavec, T.M. Mineral precipitation and porosity losses in granular iron columns. J. Hazard. Mater. 1999, 68, 1-17. [CrossRef]

106. Luo, P.; Bailey, E.H.; Mooney, S.J. Quantification of changes in zero valent iron morphology using X-ray computed tomography. J. Environ. Sci. 2013, 25, 2344-2351. [CrossRef]

107. Domga, R.; Togue-Kamga, F.; Noubactep, C.; Tchatchueng, J.-B. Discussing porosity loss of Fe packed water filters at ground level. Chem. Eng. J. 2015, 263, 127-134. [CrossRef]

108. Li, L.; Benson, C.H.; Lawson, E.M. Impact of mineral fouling on hydraulic behavior of permeable reactive barriers. Groundwater 2005, 43, 582-596. [CrossRef] [PubMed]

109. Li, L.; Benson, C.H.; Lawson, E.M. Modeling porosity reductions caused by mineral fouling in continuous wall permeable reactive barriers. J. Contam. Hydrol. 2006, 83, 89-121. [CrossRef] [PubMed]

110. Kouznetsova, I.; Bayer, P.; Ebert, M.; Finkel, M. Modeling the long term performance of zero valent iron using a spatio-temporal approach for iron aging. J. Contam. Hydrol. 2007, 90, 58-80. [CrossRef] [PubMed]

111. Weber, A.; Ruhr, A.S.; Amos, R.T. Investigating dominant processes in ZVI permeable reactive barriers using reactive transport modelling. J. Contam. Hydrol. 2013, 151, 68-82. [CrossRef] [PubMed]

112. Miyajima, K.; Noubactep, C. Characterizing the impact of sand addition on the efficiency of granular iron for contaminant removal in batch system. Chem. Eng. J. 2015, 262, 891-896. [CrossRef]

113. Liu, T.; Li, X.; Waite, T.D. Depassivation of aged $\mathrm{Fe}^{0}$ by ferrous ions: Implications to contaminant degradation. Environ. Sci. Technol. 2013, 47, 13712-13720. [CrossRef] [PubMed] 
114. Lee, H.; Lee, H.-J.; Kim, H.-E.; Kweon, J.; Lee, B.-D.; Lee, C. Oxidant production from corrosion of nano- and microparticulate zero valent iron in the presence of oxygen: A comparative study. J. Hazard. Mater. 2014, 265, 201-207. [CrossRef] [PubMed]

115. Noubactep, C. Flaws in the design of Fe(0)-based filtration systems? Chemosphere 2014, 117, $104-107$. [CrossRef] [PubMed]

116. Xiong, Z.; Lai, B.; Yang, P.; Zhou, Y.; Wang, J.; Fang, S. Comparative study on the reactivity of Fe/Cu bimetallic particles and zero valent iron (ZVI) under different conditions of $\mathrm{N}_{2}$, air or without aeration. J. Hazard. Mater. 2015, 297, 261-268. [CrossRef] [PubMed]

117. Ren, Y.; Yuan, Y.; Lai, B.; Zhou, Y.; Wang, J. Treatment of reverse osmosis (RO) concentrate by the combined $\mathrm{Fe} / \mathrm{Cu}$ /air and Fenton process (1st Fe/Cu/air-Fenton-2ndFe/Cu/air). J. Hazard. Mater. 2016, 302, 36-44. [CrossRef] [PubMed]

118. Li, L.; Benson, C.H. Evaluation of five strategies to limit the impact of fouling in permeable reactive barriers. J. Hazard. Mater. 2010, 181, 170-180. [CrossRef] [PubMed]

119. Kocur, C.M.; O'Carroll, D.M.; Sleep, B.E. Impact of nZVI stability on mobility in porous media. J. Contam. Hydrol. 2013, 145, 17-25. [CrossRef] [PubMed]

120. Mulder, M. Basic Principles of Membrane Technology; Kluwer Academic Publishers: Dordrecht, The Netherlands, 1996.

121. Ye, G.; van Breugel, P.L.K. Modeling of water permeability in cementitious materials. Mater. Struct. 2006, 39, 877-885. [CrossRef]

122. Pereira, J.-M.; Arson, C. Retention and permeability properties of damaged porous rocks. Comp. Geotech. 2013, 48, 272-282. [CrossRef]

123. Berg, C.F. Permeability description by characteristic length, tortuosity, constriction and porosity. Trans. Porous Media 2014, 103, 381-400. [CrossRef]

124. Brusaert, W. The permeability of a porous medium determined from certain probability laws for pore size distribution. Water Resour. Res. 1968, 4, 425-434. [CrossRef]

125. Brusaert, W. A concise parameterization of the hydraulic conductivity of unsaturated soils. Adv. Water Resour. 2000, 23, 811-815. [CrossRef]

126. Brusaert, W. Hydrology an Introduction; Cambridge University Press: Cambridge, UK, 2005.

127. Kaplun, K.; Li, J.; Kawashima, N.; Gerson, A.R. Cu and Fe chalcopyrite leach activation energies and the effect of added Fe ${ }^{3+}$. Geochim. Cosmochim. Acta 2011, 75, 5865-5878. [CrossRef]

128. Twigg, M.V. Catalyst Handbook, 2nd ed.; Wolfe Publishing Ltd.: London, UK, 1989.

129. Revell, L.E.; Williamson, B.E. Why are some reactions slower at higher temperatures? J. Chem. Educ. 2013, 90, 1024-1027. [CrossRef]

130. Bolobajev, J.; Trapido, M.; Goi, A. Interaction of tannic acid with ferric iron to assist 2,4,6-trichlorophenol catalytic decomposition and reuse of ferric sludge as a source of iron catalyst in Fenton-based treatment. Appl. Catal. B Environ. 2016, 187, 75-82. [CrossRef]

131. Sheng-tao, J.; Jiang-Zhong, Z.; Shu-li, B.; Yu-jiang, G. Research on Fe-loaded ZSM-5 molecular sieve catalyst in high concentration aniline wastewater treatment. Desalt. Water Treat. 2016, 57, 791-798. [CrossRef]

132. Xiong, H.; Motchelaho, M.A.; Moyo, M.; Jewell, L.L.; Coville, N.J. Effect of Group 1 alkali metal promoters on Fe/CNT catalysts in Fischer-Tropsch synthesis. Fuel 2015, 150, 687-696. [CrossRef]

133. Vlamidis, Y.; Scavetta, E.; Gazzano, M.; Tonelli, D. Iron vs. aluminium based layered double hydroxides as water splitting catalysts. Electrochim. Acta 2016, 188, 653-660. [CrossRef]

134. Bouniol, P. Influence of iron on water radiolysis in cement based materials. J. Nucl. Mater. 2010, 403, 167-183.

135. Chen, K.-F.; Li, S.; Zhang, W.-X. Renewable hydrogen generation by bimetallic zero valent iron nanoparticles. Chem. Eng. J. 2011, 170, 562-567. [CrossRef]

136. Reardon, E.J. Capture and storage of hydrogen gas by zero valent iron. J. Contam. Hydrol. 2014, 157, 117-124. [CrossRef] [PubMed]

137. Ruhl, A.S.; Jekel, M. Degassing, gas retention and release in Fe(0) permeable reactive barriers. J. Contam. Hydrol. 2014, 159, 11-19. [CrossRef] [PubMed]

138. Reardon, E.J. Anaerobic corrosion of granular iron: Measurement and interpretation of hydrogen evolution rates. Environ. Sci. Technol. 1995, 29, 2936-2945. [CrossRef] [PubMed]

139. Miller, E.L.; Rochealeau, R.E. Electrochemical behaviour of reactively spluttered iron-doped nickel oxide. J. Electrochem. Soc. 1997, 144, 3072-3077. [CrossRef] 
140. Fominykh, K.; Chernev, P.; Zaharieva, I.; Sicklinger, J.; Stefanic, G.; Doblinger, M.; Muller, A.; Pokharel, A.; Bocklein, S.; Scheu, C.; et al. Iron-doped nickel oxide as highly efficient catalysts for alkaline water splitting. ACS Nano 2015, 9, 5180-5188. [CrossRef] [PubMed]

141. Haber, J.; Block, J.H.; Delmon, B. Manual of methods and procedures for catalyst characterization (IUPAC Subcommittee on catalyst characterization). Pure Appl. Chem. 1995, 67, 1257-1306. [CrossRef]

142. Misstear, B.; Banks, D.; Clark, L. Water Wells and Boreholes; John Wiley \& Sons Ltd.: Chichester, UK, 2006.

143. Lesch, S.M.; Suarez, D.L. A short note on calculating the adjusted SAR index. Trans. Am. Soc. Agric. Biol. Eng. 2009, 52, 493-496.

144. Scholl, S.E.; Mersmann, A.B. On intraparticle total pressure change during gas phase adsorption. Gas. Sep. Purif. 1991, 5, 77-82. [CrossRef]

145. Kozin, P.A.; Boily, J.F. Proton binding and ion exchange at the akaganeite/water interface. J. Phys. Chem. C 2013, 117, 6409-6419. [CrossRef]

146. Naftz, D.L.; Morrison, S.J.; Davis, J.A.; Fuller, C.C. Handbook of Groundwater Remediation Using Permeable Reactive Barriers; Academic Press: San Diego, CA, USA, 2002.

147. Zhao, J.; Lin, W.; Chang, Q.; Li, W.; Lai, Y. Adsoptive characteristics of akaganeite and its environmental applications: A review. Environ. Technol. Rev. 2012, 1, 114-126. [CrossRef]

148. Scheck, J.; Lemke, T.; Gebauer, D. The role of chloride ions during the formation of akaganeite revisited. Minerals 2015, 5, 778-787. [CrossRef]

149. Wang, W.; Howe, J.Y.; Gu, B. Structure and morphology evolution of hematite $\left(\alpha-\mathrm{Fe}_{2} \mathrm{O}_{3}\right)$ nanoparticles in forced hydrolysis of ferric chloride. J. Phys. Chem. C 2008, 112, 9203-9208. [CrossRef]

150. Zhou, P.; Yan, H.; Gu, B. Competitive complexation of metal ions with humic substances. Chemosphere 2014, 58, 1327-1337. [CrossRef] [PubMed]

151. Gu, B.; Schmitt, J.; Chen, Z.; Liang, L.; McCarthy, J.F. Adsorption and desorption of natural organic matter on iron oxide: Mechanisms and models. Environ. Sci. Technol. 1994, 28, 38-46. [CrossRef] [PubMed]

152. Gu, B.; Schmitt, J.; Chen, Z.; Liang, L.; McCarthy, J.F. Adsorption and desorption of different organic matter fractions on iron oxide. Geochim. Cosmochim. Acta 1995, 59, 219-229. [CrossRef]

153. Gu, B.; Mehlorn, T.L.; Liang, L.; McCarthy, J.F. Competitive adsorption, displacement, and transport of organic matter on iron oxide: I. Competitive adsorption. Geochim. Cosmochim. Acta 1996, 60, 1943-1950. [CrossRef]

154. Gu, B.; Mehlorn, T.L.; Liang, L.; McCarthy, J.F. Competitive adsorption, displacement, and transport of organic matter on iron oxide: II displacement and transport. Geochim. Cosmochim. Acta 1996, 60, 2977-2992. [CrossRef]

155. Gu, B.; Phelps, T.J.; Liang, L.; Dickey, M.J.; Roh, Y.; Kinsall, B.L.; Palumbo, A.V.; Jacobs, G.K. Biogeochemical dynamics in zero valent iron columns: Implications for permeable reactive barriers. Environ. Sci. Technol. 1999, 33, 2170-2177. [CrossRef]

156. Liang, L.; Hofmann, A.; Gu, B. Ligand-induced dissolution and release of ferrihydrite colloids. Geochim. Cosmochim. Acta 2000, 64, 2027-2037. [CrossRef]

157. Lee, J.-H.; Roh, Y.; Kim, K.-W.; Hur, H.-G. Organic acid dependent iron mineral formation by a newly isolated iron reducing bacterium, Shewanella sp. HN-41. Geomicrobiol. J. 2012, 24, 31-41. [CrossRef]

158. Chen, J.; Gu, B.; Royer, R.A.; Burgos, W.D. The roles of natural organic matter in chemical and microbial reduction of ferric iron. Sci. Total Environ. 2003, 307, 167-178. [CrossRef]

159. Peng, Q.-A.; Shaaban, M.; Wu, Y.; Hu, R.; Wang, B.; Wang, J. The diversity of iron reducing bacteria communities in subtropical paddy soils of China. Appl. Soil Ecol. 2016, 101, 20-27. [CrossRef]

160. Ko, M.-S.; Cho, K.; Jeong, D.; Lee, S. Identification of the microbes mediating Fe reduction in a deep saline aquifer and their influence during managed aquifer recharge. Sci. Total Environ. 2016, 545-546, 486-492. [CrossRef] [PubMed]

161. Fernandes, C.E.G.; Gonsalves, M.J.B.D.; Nazareth, D.R.; Nagarchi, L. Microbial iron reduction and methane oxidation in subsurface sediments of the Arabian Sea. Mar. Petrol. Geol. 2015, 67, 327-335. [CrossRef]

(C) 2016 by the author; licensee MDPI, Basel, Switzerland. This article is an open access article distributed under the terms and conditions of the Creative Commons by Attribution (CC-BY) license (http://creativecommons.org/licenses/by/4.0/). 